\title{
Crustal Structure of the Cascadia Fore Arc of Washington
}

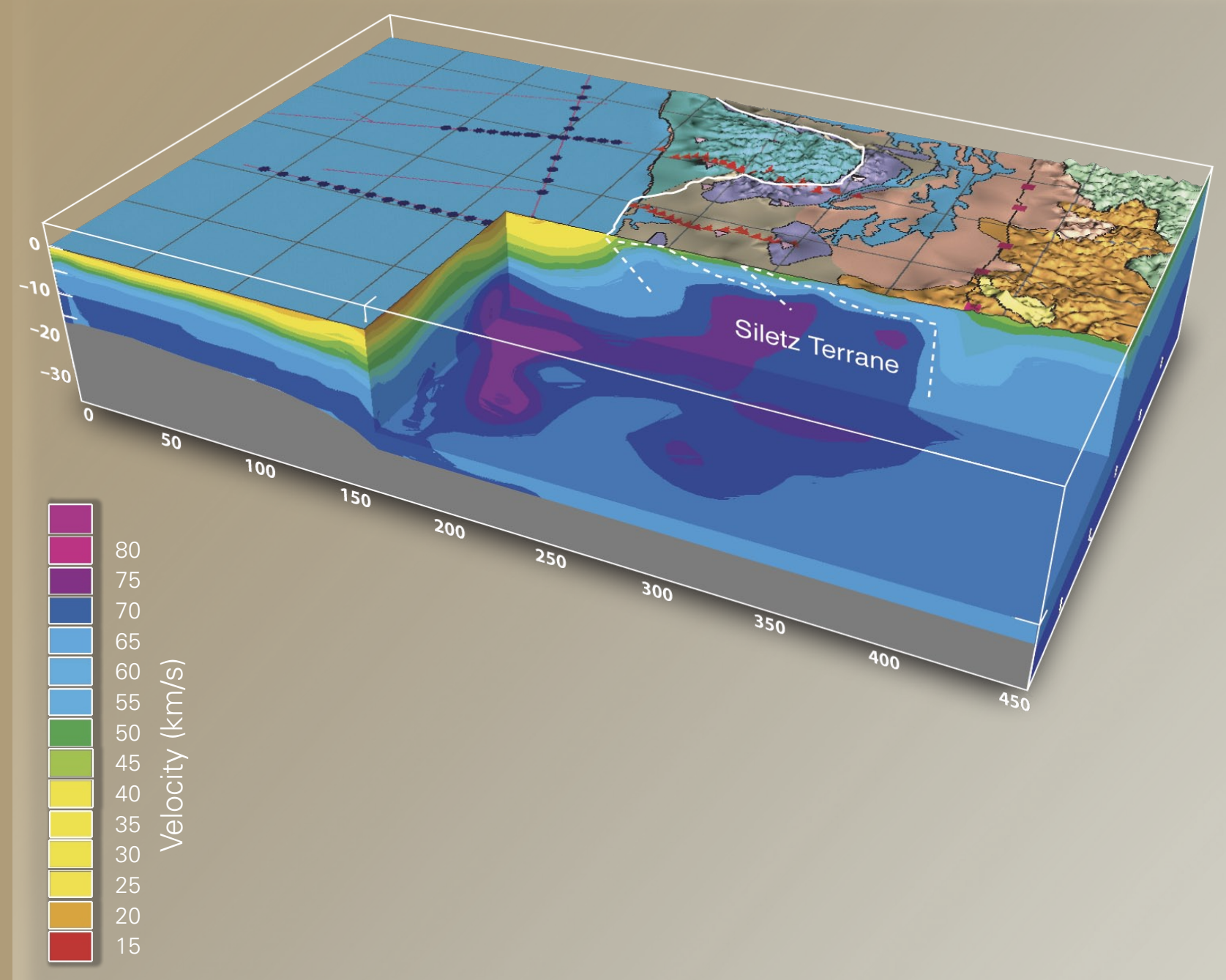

Professional Paper 1661-D

U.S. Department of the Interior U.S. Geological Survey 


\section{Earthquake Hazards of the Pacific Northwest Costal and Marine Regions}

Robert Kayen, Editor

\section{Crustal Structure of the Cascadia Fore Arc of Washington}

By Tom Parsons, Richard J. Blakely, Thomas M. Brocher, Nikolas I. Christensen, Michael A. Fisher,

Ernst Flueh, Fiona Kilbride, James H. Luetgert, Kate Miller, Uri S. ten Brink, Anne M. Trehu, and Ray E. Wells

Crustal structure and tectonic models of the subduction margin of Washington are derived from onshore and offshore seismic data and gravity observations.

Professional Paper 1661-D 


\section{U.S. Department of the Interior \\ Gale A. Norton, Secretary}

\section{U.S. Geological Survey P. Patrick Leahy, Acting Director}

\section{U.S. Geological Survey, Reston, Virginia: 2005}

For sale by U.S. Geological Survey Information Services Box 25286, Denver Federal Center Denver, C0 80225

This report and any updates to it are available online at: http://pubs.usgs.gov/pp/pp1661-D

For additional information write to: U.S. Geological Survey Box 25046, Mail Stop 421, Denver Federal Center Denver, C0 80225-0046

Additional USGS publications can be found at: http://geology.usgs.gov/products.html

For more information about the USGS and its products: Telephone: 1-888-ASK-USGS (1-888-275-8747)

World Wide Web: http://www.usgs.gov/

Any use of trade, product, or firm names in this publication is for descriptive purposes only and does not imply endorsement of the U.S. Government.

Cataloging-in-publication data are on file with the Library of Congress (URL http://www.loc.gov/).

Produced in the Western Region, Menlo Park, California

Manuscript approved for publication, November 21, 2005

Text edited by Peter Stauffer

Layout and design by Judy Weathers

FRONT COVER

Cutaway view into the three-dimensional seismic velocity structure of the Washington margin calculated with traveltime observations from earthquakes, explosions, and airguns. Velocity was found by minimizing residual times between calculated and observed. Lower velocities (warm colors) characterize the accretionary prism rocks offshore, whereas higher velocities (cool colors) are seen in the Siletz River volcanic rocks, partly outlined by the white dashed lines. Surface geology and coastlines are draped onto the topography. 


\section{Contents}

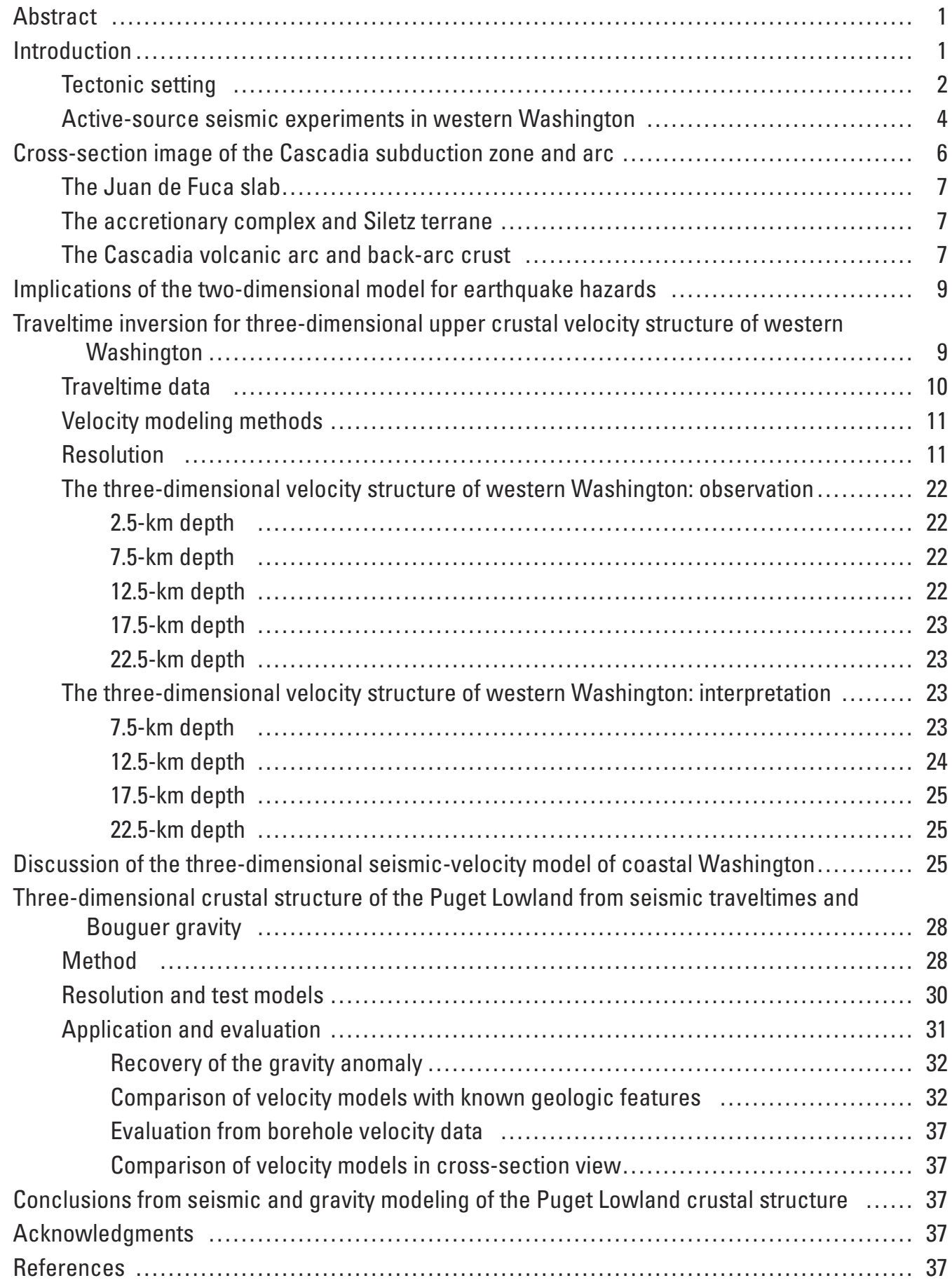




\section{Figures}

1. Map showing major tectonic elements of the Cascadia subduction zone $\ldots \ldots \ldots \ldots \ldots \ldots .2$

2. Map showing location of two-dimensional seismic traverse in relation to major geologic

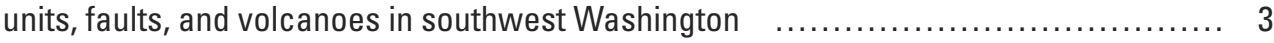

3. Map showing locations of the controlled and earthquake sources and recording stations used to construct the three-dimensional velocity model ............................ 4

4. Example of a seismic profile from explosive-source data collected on land in southwest

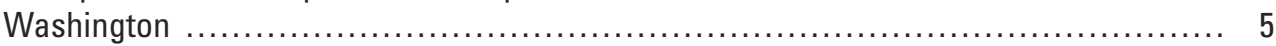

5. Example of a seismic profile from airgun data collected on land .................... 5

6. Map showing location of Seismic Hazards Investigation in Puget Sound (SHIPS) seismo-

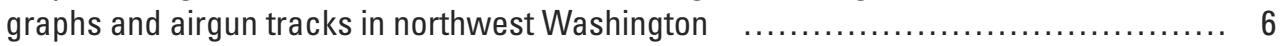

7. Velocity-structure model across Cascadia subduction zone and arc $\ldots \ldots \ldots \ldots \ldots \ldots \ldots . \ldots$

8. Example of local earthquake data collected on the vertical component ................. 10

9. Horizontal slice of three-dimensional velocity model at $2.5-\mathrm{km}$ depth .................. 12

10. Horizontal slice of three-dimensional velocity model at $7.5-\mathrm{km}$ depth .................. 14

11. Horizontal slice of three-dimensional velocity model at $12.5-\mathrm{km}$ depth $\ldots \ldots \ldots \ldots \ldots \ldots \ldots \ldots$

12. Horizontal slice of three-dimensional velocity model at $17.5-\mathrm{km}$ depth $\ldots \ldots \ldots \ldots \ldots \ldots \ldots \ldots \ldots$

13. Horizontal slice of three-dimensional velocity model at $22.5-\mathrm{km}$ depth $\ldots \ldots \ldots \ldots \ldots \ldots 20$

14. Average velocity-depth curves for major classes of sedimentary, metamorphic, and

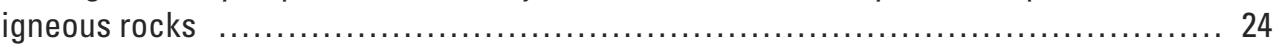

15. Spaced vertical profiles though the three-dimensional velocity model for coastal

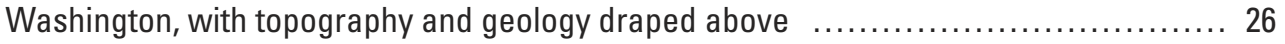

16. Diagrams showing the tectonic model of Siletz-terrane deformation ................... 29

17. Plot of observed velocity vs. density from Puget Lowland rock samples compared with

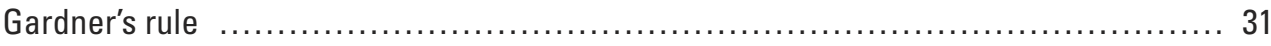

18. Graph showing velocity-depth profiles derived using traveltimes only and using both traveltimes and gravity in relation to seismic coverage with depth $\ldots \ldots \ldots \ldots \ldots \ldots \ldots \ldots \ldots \ldots \ldots$

19. Map-view images showing the checkerboard resolution tests at $5-\mathrm{km}$ depth ............ 32

20. Maps showing distribution of gravity observations, SHIPS seismic sources and receivers,

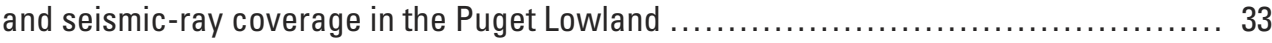

21. Map-view images comparing the gravity anomaly calculated from velocity models with

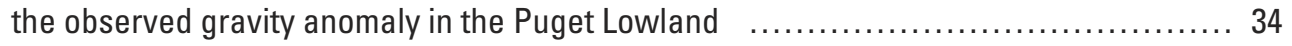

22. Horizontal slices from the three-dimensional model at $5-\mathrm{km}$ depth derived from traveltime-

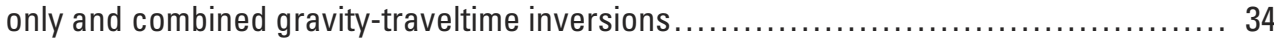

23. Graphs showing comparison of tomography results with sonic-log data and lithologies for

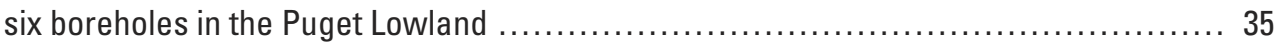

24. Comparative east-west cross section from the three-dimensional velocity models derived from combined gravity and traveltime analysis and from traveltime modeling only.... 


\title{
Crustal Structure of the Cascadia Fore Arc of Washington
}

\author{
By Tom Parsons' ${ }^{1}$, Richard J. Blakely ${ }^{1}$, Thomas M. Brocher' ${ }^{1}$ Nikolas I. Christensen², Michael A. Fisher ',Ernst Flueh, \\ Fiona Kilbride ${ }^{4}$, James H. Luetgert' ${ }^{1}$, Kate Miller ${ }^{5}$, Uri S. ten Brink ${ }^{6}$, Anne M. Trehu ${ }^{7}$, and Ray E. Wells ${ }^{1}$
}

\section{Abstract}

This paper discusses three crustal-structure models developed because of the significant seismic hazard posed by Cascadia subduction margin to the highly populated Pacific Northwest region of the United States. The first is a 530-kmlong wide-angle onshore-offshore seismic transect across the subduction zone and volcanic arc recorded to study the major structures that contribute to seismogenic deformation. Observed were (1) an increase in the dip of the Juan de Fuca slab from $2^{\circ}-7^{\circ}$ to $12^{\circ}$ where it encounters a 20 -km-thick block of the Siletz terrane or other accreted oceanic crust, (2) a distinct transition from Siletz crust into Cascade arc crust that coincides with the Mount St. Helens seismic zone, supporting the idea that the mafic Siletz block focuses seismic deformation at its edges, and (3) a crustal root (35-45 km deep) beneath the Cascade Range, with thinner crust (30-35 km) east of the volcanic arc beneath the Columbia Plateau flood basalt province. From the measured crustal structure and subduction geometry, two zones were identified that may concentrate future seismic activity: (1) a broad (because of the shallow dip), possibly locked part of the interplate contact that extends westward from $\sim 25 \mathrm{~km}$ depth beneath the coastline perhaps as far as the deformation front $\sim 120 \mathrm{~km}$ offshore and (2) a crustal zone at the eastern boundary between the Siletz terrane and the Cascade Range.

In addition to the two-dimensional cross-section model, two three-dimensional crustal models are discussed. The first is a regional model developed to study the Eocene mafic crust with high seismic velocities that underlies much of the Oregon and Washington fore arc and acts as a backstop for accretion of marine sedimentary rocks from the obliquely subducting Juan de Fuca slab. Arc-parallel migration of relatively strong

\footnotetext{
${ }^{1}$ U.S. Geological Survey, Menlo park, California 94025

${ }^{2}$ Department of Geology and Geophysics, University of Wisconsin, Madison, Wisconsin 53706

${ }^{3}$ GEOMAR Research Center for Marine Geosciences, Kiel, Germany

${ }^{4}$ Anadarko Petroluem Corporation, P.O. Box 1330, Houston, Texas 77251

${ }^{5}$ Department of Geological Sciences, University of Texas at El Paso, El Paso, Texas 79968

${ }^{6}$ U.S. Geological Survey, Woods Hole, Massachusetts 02543

${ }^{7}$ College of Oceanic and Atmospheric Sciences, Oregon State University, Corvallis, Oregon 97331
}

blocks of this terrane, known as Siletzia, focuses upper crustal deformation and seismicity along block boundaries, which are potential sources of earthquakes. In a three-dimensional velocity model of coastal Washington, surface geology, well data, and traveltimes from earthquakes and controlled-source seismic experiments were combined to resolve the major boundaries of the Siletz terrane with the adjacent accreted sedimentary prism and volcanic arc. In southern Washington and northern Oregon, the Siletz terrane appears to be a thick block $(\sim 20$ $\mathrm{km})$ that extends west of the coastline and makes a high-angle contact with the offshore accreted sedimentary prism. On its east flank, the high-velocity Siletz terrane boundary coincides with an en echelon zone of seismicity in the arc. In northern Washington, the western edge of Siletzia makes a lower angled, fault-bounded contact with the accretionary prism. In addition, alternating, east-west-trending uplifts and downwarps of the Siletz terrane centered on the antiformal Olympic Mountains may reflect focusing of north-south compression in the northern part of the Siletz terrane. This compressional strain may result from northward transport and clockwise rotation of Siletz terrane into the relatively fixed restraining bend of the Canadian Coast Mountains.

The final crustal model discussed is one of upper crustal structure in the highly populated Puget Lowlands of Washington determined from data gathered during the 1998 Seismic Hazards Investigation in Puget Sound (SHIPS) experiment. A new method was developed to sequentially minimize seismic traveltime and observed gravity residuals in an iterative threedimensional inversion. Resolution tests were performed with synthetic traveltime and gravity observations from a checkerboard velocity model using the SHIPS experiment geometry, and it was shown that the addition of gravity significantly enhances resolution. The new velocity model for the region shows better correlation between surface geology and modeled subsurface velocity structure, and basin structures in particular were much better resolved.

\section{Introduction}

Between 1991 and 1998, a series of controlled-source seismic experiments were conducted in Oregon and Washington to determine the velocity structure of the seismically active Cascadia convergent margin (Tréhu and others, 1994, Miller 
and others, 1997; Flueh and others, 1997; Parsons and others, 1998; Fisher and others, 1999). Crustal structure models derived from this work are here presented at three different scales: (1) a two-dimensional cross-section model through the subduction zone in southern Washington, (2) a three-dimensional seismic tomographic analysis of controlled-source and earthquake traveltime data aimed at resolving the large-scale geometry of the thick Eocene mafic basement of the Washington fore arc and its relationship to the accretionary prism and volcanic arc, and (3) a three-dimensional image of the upper crust of the Puget Lowland based on seismic and gravity data.

\section{Tectonic Setting}

The Juan de Fuca Plate subducts beneath North America at a rate of $\sim 40 \mathrm{~mm} / \mathrm{yr}$ on a $68^{\circ} \mathrm{E}$ azimuth (DeMets and others, 1990). This oblique subduction has created a complex, geologically diverse, and potentially hazardous region, the Cascadia subduction zone and volcanic arc (fig. 1). No great earthquakes on the Cascadia subduction zone have been recorded in written history, and much of the region is relatively quiet seismically (Dewey and others, 1989). However, global comparisons indicate that the Cascadia subduction zone has many characteristics in common with those that produce great interplate earthquakes; for example, young oceanic lithosphere subducts at shallow dip (similar to Central and South America, southwest Japan, and the Aleutians) (Heaton and Kanamori, 1984; Heaton and Hartzell, 1987). Recent studies of the Holocene geologic record have shown consistent indications that great subduction-zone and/or large upper-plate earthquakes have affected the Washington coastal margin. Interpretation of geologic evidence (subsidence, tsunami deposits) along the coast has suggested that great earthquakes $(M>8)$ have occurred in the Cascadia subduction zone on a recurrence interval of hundreds of years (Atwater, 1996).

The Cascadia margin has had a long and complex history of deformation and volcanism resulting from Cenozoic

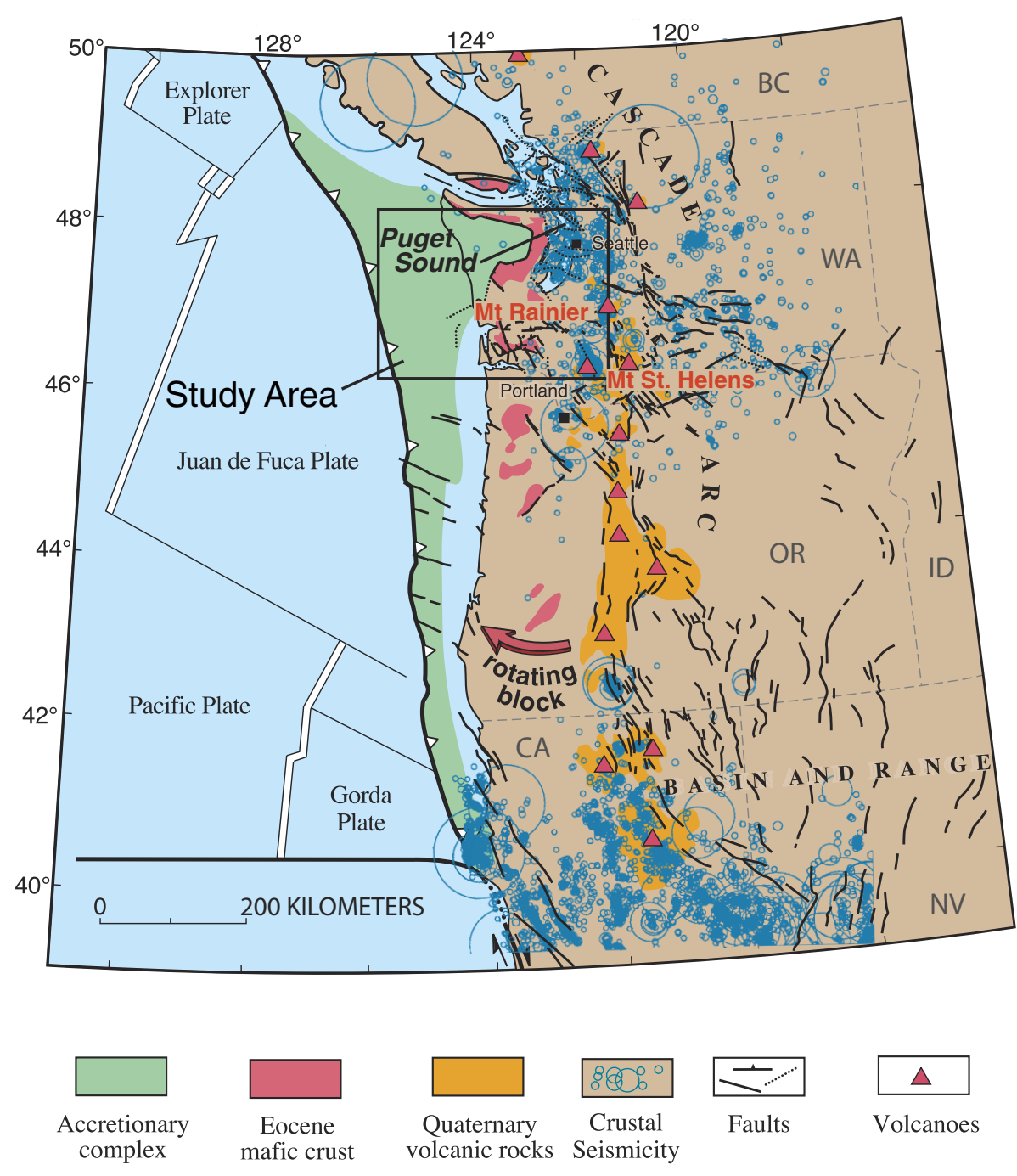

Figure 1. Major tectonic elements of the Cascadia subduction zone. There are important structural variations along the margin. The accretionary complex broadens progressively along the margin, reaching its widest point at the Olympic Mountains. Volcanic production is greatest in the central arc, where the seismicity rate is lowest. 
oblique convergence between North America and subducting oceanic plates. In the Washington fore arc, Cenozoic marine sedimentary rocks overlie Eocene basaltic basement of the Crescent Formation, which extend, along with the correlative Siletz River Volcanics of Oregon, from the southern tip of Vancouver Island to the Klamath Mountains (Snavely and others, 1968; Snavely and Wells, 1996) (figs. 1,2). Sutured to North America at about $50 \mathrm{Ma}$, these voluminous (5-25 $\mathrm{km}$ thick) submarine and subaerial basalts may represent an accreted oceanic island chain (Simpson and Cox, 1977; Duncan, 1982) or a hot spot-generated continental margin rifting event (Wells and others, 1984; Babcock and others, 1992). Paleomagnetic observations from volcanic rocks of the Eocene Crescent Formation in southwest Washington show significant $\left(\sim 20^{\circ}-50^{\circ}\right)$ clockwise rotations, as does the Cascade arc, the result of oblique subduction of the Juan de Fuca Plate (Wells and Coe, 1985; Beck and Burr, 1979). Marine sedimentary rocks accreted against the Eocene volcanic rocks and have been exhumed since $\sim 14 \mathrm{Ma}$ in the Olympic Mountains, maintaining a steady-state elevation since that time, with erosion balancing tectonic uplift (Brandon and others, 1998).

Some knowledge about the subducted Juan de Fuca slab beneath the continent has been acquired through controlledsource experiments, studies of regional earthquake hypocenters, and inversion of teleseismic arrival times for velocity structure. Taber and Lewis (1986) modeled a $9^{\circ}$ dip on the Juan de Fuca slab beneath Grays Harbor. More broadly, the Juan de Fuca Plate appears to be arched beneath Washington along an axis oriented southwest-northeast that crosses the northern part of the Puget Sound (Crosson and Owens, 1987). Interpretation of teleseismic traveltime delays suggests a possible tear in the descending Juan de Fuca slab, with the dip angle steepening south of the Willapa Bay-Columbia River region (Michaelson and Weaver, 1986).

Seismic activity in western Washington is very low along the coast and increases inland, with hypocenters most abundant beneath the Cascade Range and Puget Sound (fig. 1). Deep earth-

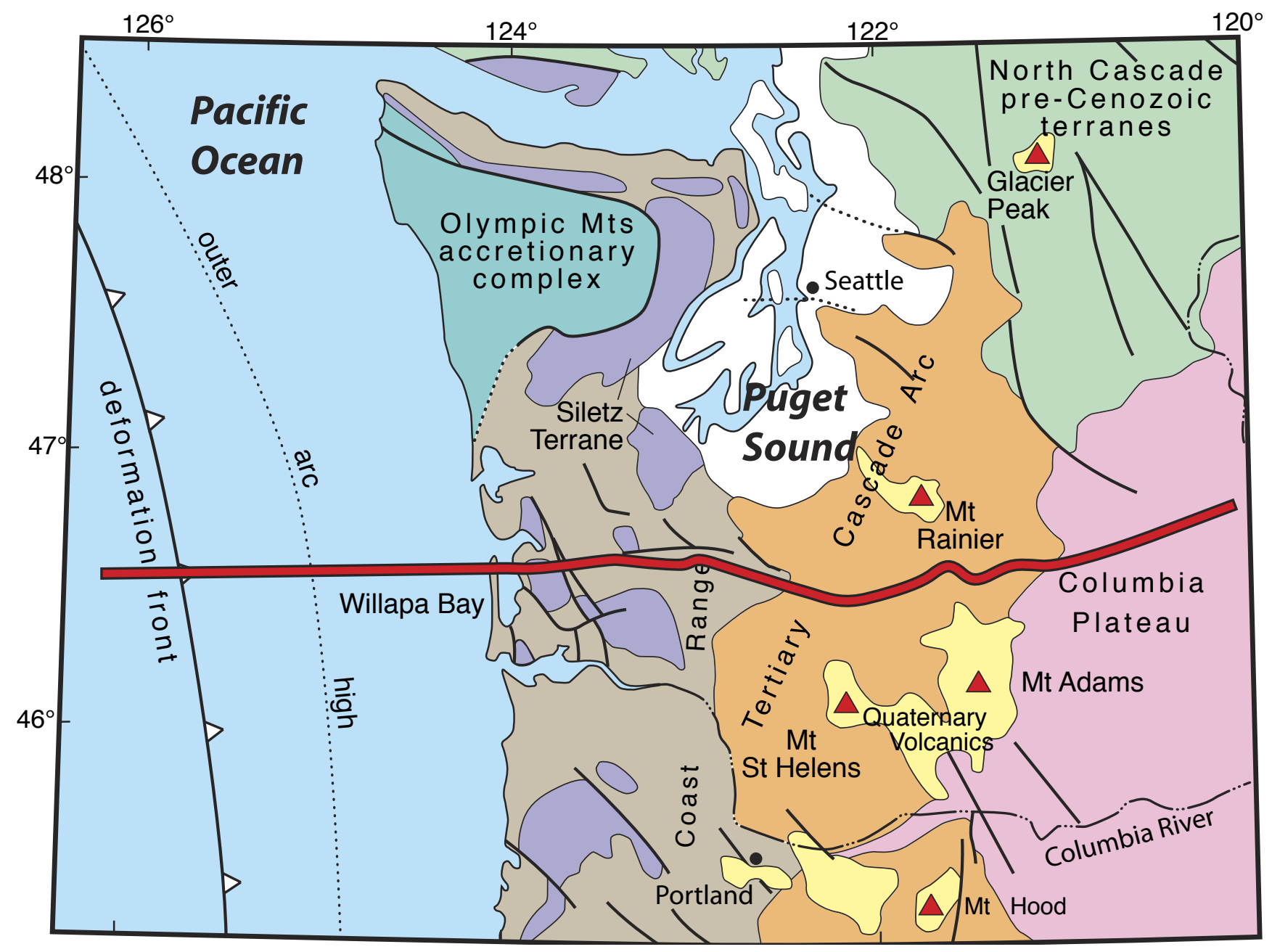

Figure 2. Location of two-dimensional seismic traverse (red line) in relation to major geologic units, faults, and volcanoes in southwest Washington. 
quakes associated with the Juan de Fuca slab seem to mirror the distribution of upper plate earthquakes in the fore arc. Two distinct north-northwest-trending zones of shallow seismicity are associated with Mount St. Helens and Mount Rainier (Stanley and others, 1996) (fig. 1). Heat flow in coastal Washington is low $\left(\sim 20-50 \mathrm{mWm}^{-2}\right)$, increasing to the east in the Cascade Range $\left(\sim 50-100 \mathrm{mWm}^{-2}\right)$ and Columbia Plateau $\left(\sim 50 \mathrm{mWm}^{-2}\right)$ (Blackwell and others, 1990).

\section{Active-Source Seismic Experiments in Western Washington}

In 1991, the U.S. Geological Survey (USGS), in collaboration with the University of Texas at El Paso, Oregon State University, the Geological Survey of Canada, the University of British Columbia, and the University of Wyoming, collected a series of refraction profiles in Oregon and Washington (Miller and others, 1997). Traveltimes from the northernmost refraction profile that trended along the eastern side of Puget Sound (fig. 3) were applied in this study. This profile was defined by 10 large explosive sources detonated into a 465-channel land array ( $600 \mathrm{~m}$ spacing) that was about $300 \mathrm{~km}$ long. Six sources from that study are applied here (fig. 3).

In 1995, wide-angle seismic data were collected by the same collaborators along a 325-km-long east-west-trending profile that crossed southern Washington from Willapa Bay to the Columbia Plateau (fig. 2) (Parsons and others, 1998). On that profile, about 1,500 instrument deployments were spaced at 200-m intervals and 17 large explosive sources were recorded. An example of these data is shown in figure 4. The explosion data show images of the subducting slab (from reflections) and provide continuous first arrivals to $230-\mathrm{km}$ offsets.

In 1996, the German research vessel FS Sonne conducted an extensive investigation of the offshore Oregon and Washington margins in a joint effort by the Research Center for Marine Geosciences (GEOMAR) and the USGS (Flueh and others, 1997). A total of more than 14,500 air-gun sources (50-150 m spacing) were fired offshore of Washington, with about 6,000 detonated along lines instrumented by a cumulative total of 53 ocean-bottom recorder deployments (fig. 3). The balance of the air-gun sources were fired for marine multichannel profiles. On land, 44 Reftek

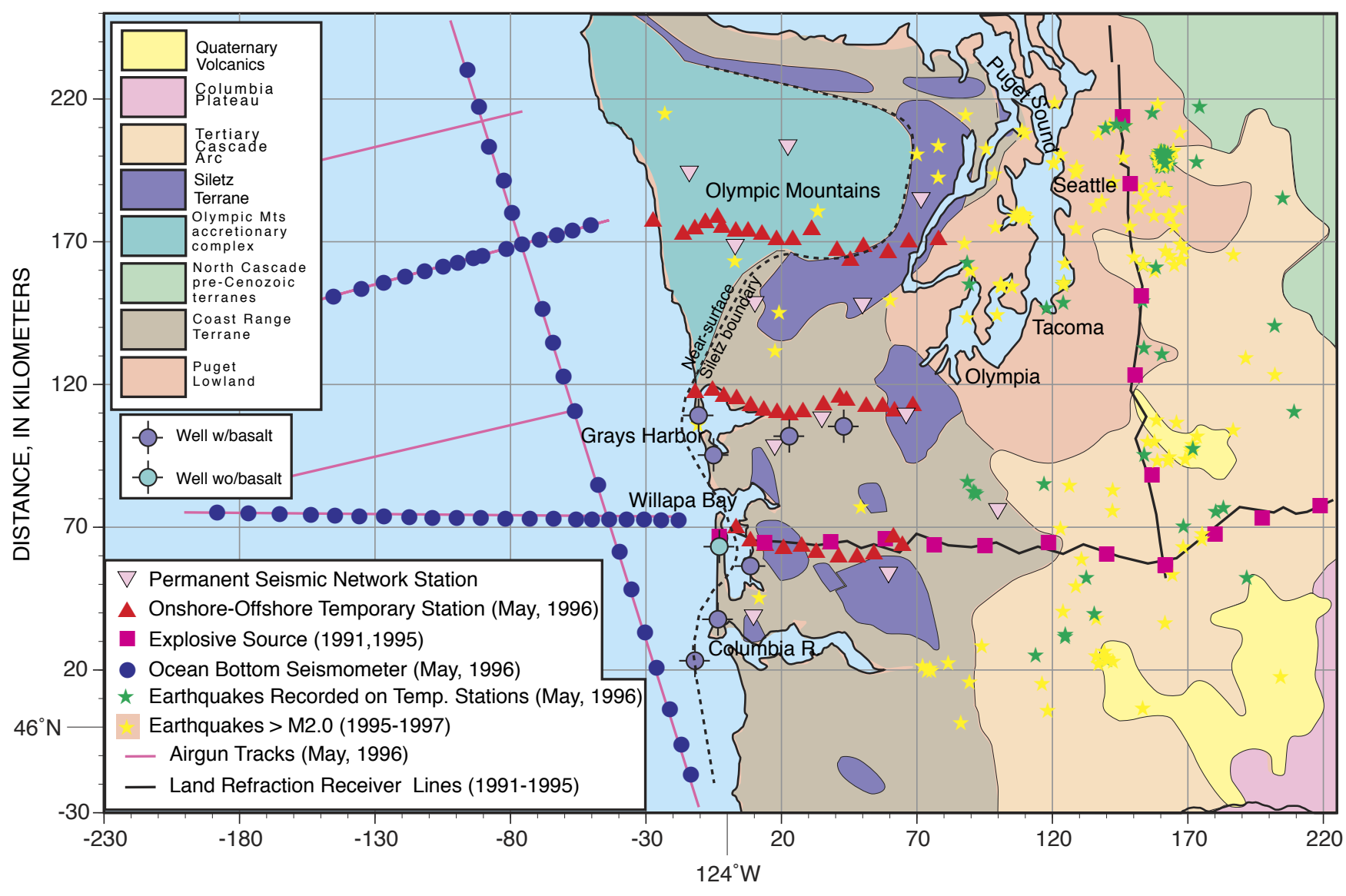

DISTANCE, IN KILOMETERS

Figure 3. Locations of the controlled and earthquake sources and recording stations used to construct the three-dimensional velocity model. The generalized onshore geology is shown along with the locations of wells used (McFarland, 1979) to define the near-surface location of Siletzia, shown by the dashed black line. 
seismographs distributed ( $\sim \mathrm{km}$ linear spacing) along three profiles (fig. 3) recorded all the air-gun sources continuously. The ocean-bottom and on-land profileswere aligned along east-west profiles to provide continuous phase coverage across the margin and to enable comparison of structure from south to north (fig. 3). An example of air-gun data recorded on land is shown in figure 5. The onshore-offshore data show headwaves traveling down the subducting slab as first arrivals in the near offsets and continental upper mantle refractions at longer offsets.

In March of 1998, the Seismic Hazards In Puget Sound (SHIPS) experiment was conducted in the connected waterways of the Puget Lowland. The SHIPS experiment consisted of onshore-offshore wide-angle and multichannel seismic (MCS) reflection profiling throughout the Puget Lowland

\section{Land Shot 1}

0

OFFSET, IN KILOMETERS

160

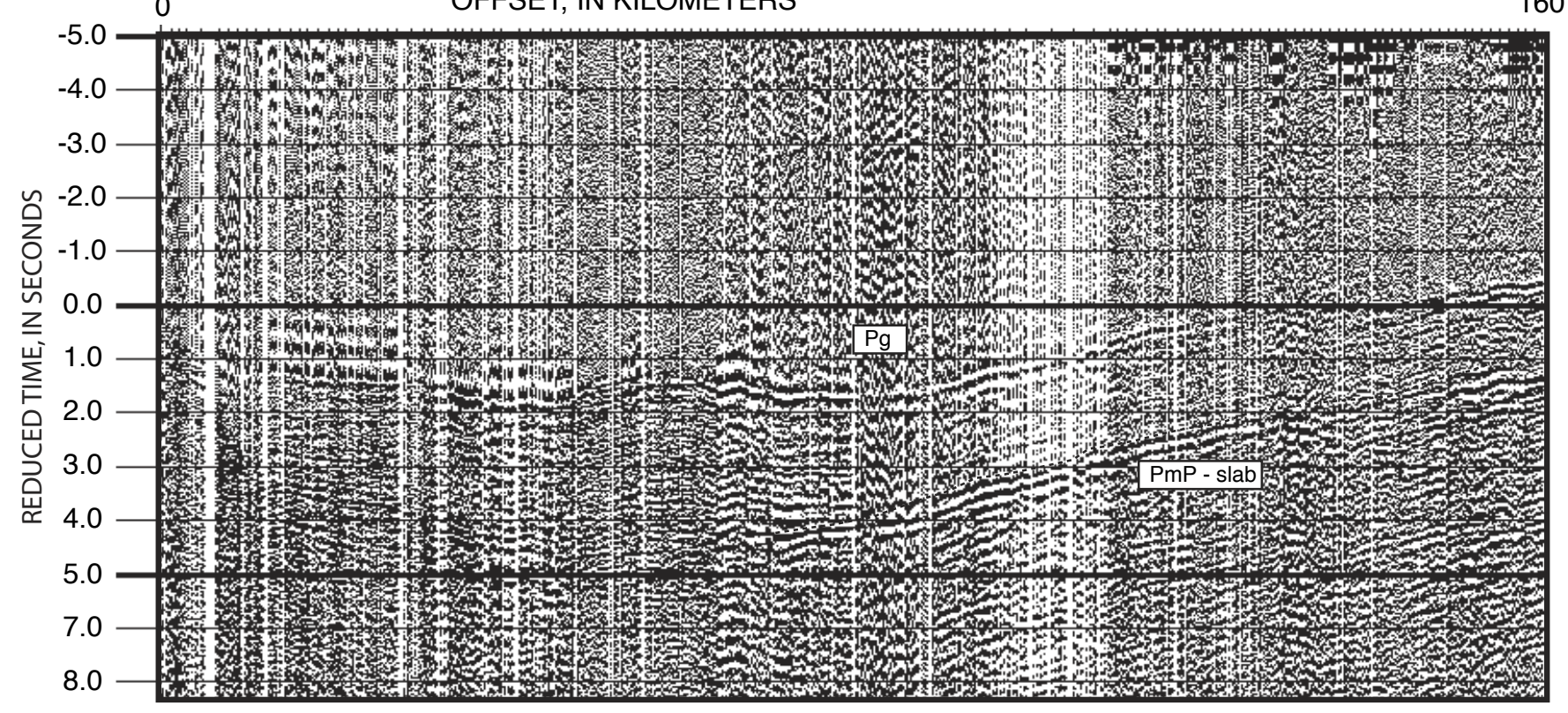

Figure 4. An example of explosive-source data collected on land in southwest Washington, showing the crustal refracted phase, Pg, that was used in the traveltime inversion for velocity structure. Reflected phases such as the one shown from the Juan de Fuca slab were not applied. Time scale was reduced as time less offset divided by $6.0 \mathrm{~km} / \mathrm{s}(\mathrm{t}-\mathrm{x} / 6.0)$.

\section{Onshore-Offshore Station 5}

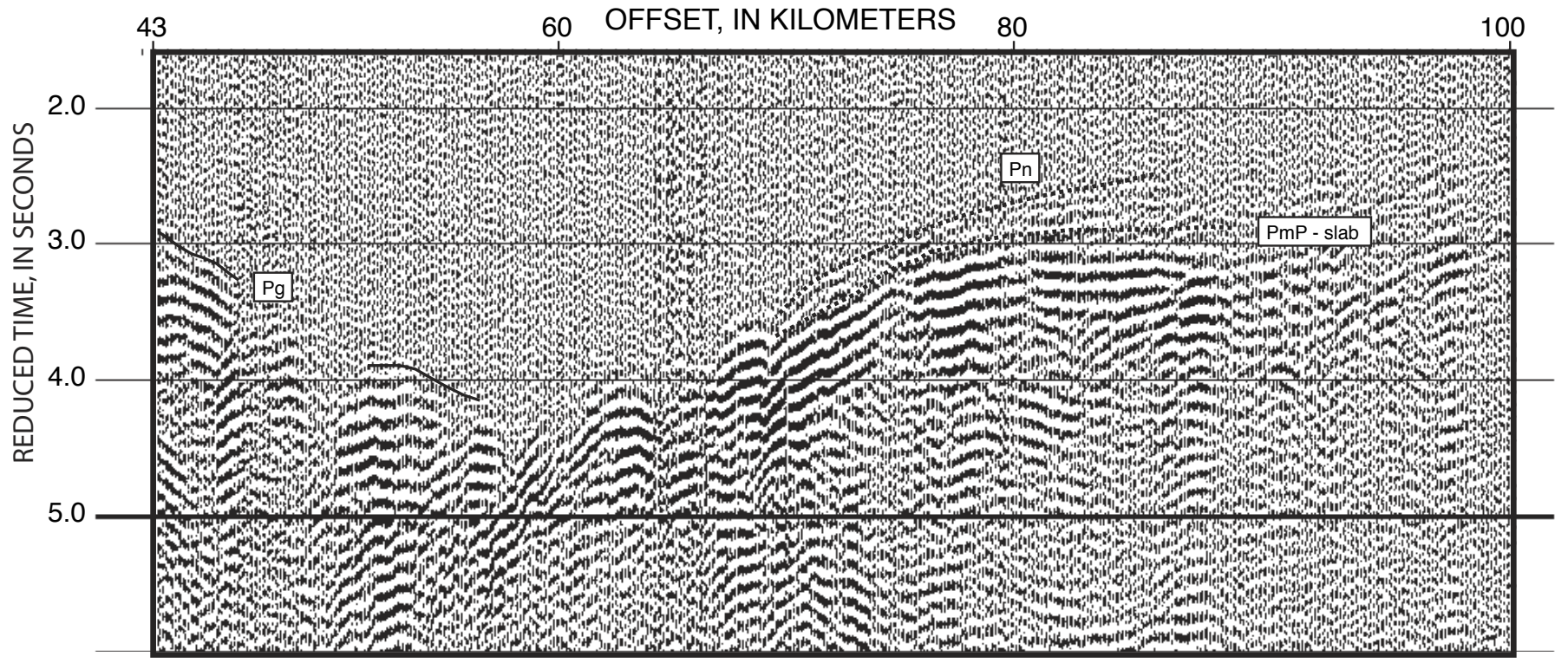

Figure 5. An example of airgun data collected on land showing the Pg phase and the upper mantle refracted phase, $\mathrm{Pn}$, that were used in the traveltime inversion for velocity structure. Time scale was reduced as time less offset divided by $6.0 \mathrm{~km} / \mathrm{s}(\mathrm{t}-\mathrm{x} / 6.0)$. 
using an air-gun array (fig. 6). The total volume of the air-gun array varied between 110.3 litres and 79.3 litres, depending on whether wide-angle or MCS data were acquired. Wideangle profiling was conducted throughout the study region, even in narrow waterways such as the Hood Canal and Lake Washington where the multichannel seismic streamer could not be towed (Fisher and others, 1999). MCS profiling was performed in Puget Sound and the Strait of Juan de Fuca (fig. 6). Air-gun shotpoint locations and times accurate to a millisecond were determined from global positioning system (GPS) navigation and GPS time recorded on the ship. The database includes 977,000 traveltime picks from controlled sources.

The air-gun shots were recorded by a temporary array of 210 seismographs deployed onshore and on the floor of Puget Sound (fig. 6) (Brocher and others, 1999). The SHIPS data were acquired with a shot spacing between 50 and $150 \mathrm{~m}$ and receiver spacing between 5 and $15 \mathrm{~km}$. The quality of the wideangle data obtained during SHIPS is highly variable, although most stations provided useful data to source-receiver offsets of at least 40-50 km. At bedrock sites remote from urban centers, first arrivals can be observed to ranges as far as $200 \mathrm{~km}$. On the other hand, few interpretable data were recorded at some of the soft soil sites in urban or suburban localities.

\section{Cross-Section Image of the Cascadia Subduction Zone and Arc}

The 1995 wide-angle seismic profile was extended offshore in 1996, when the FS Sonne fired about 2,000 offshore air-gun sources ( $25 \mathrm{~m}$ spacing) into 35 instruments located

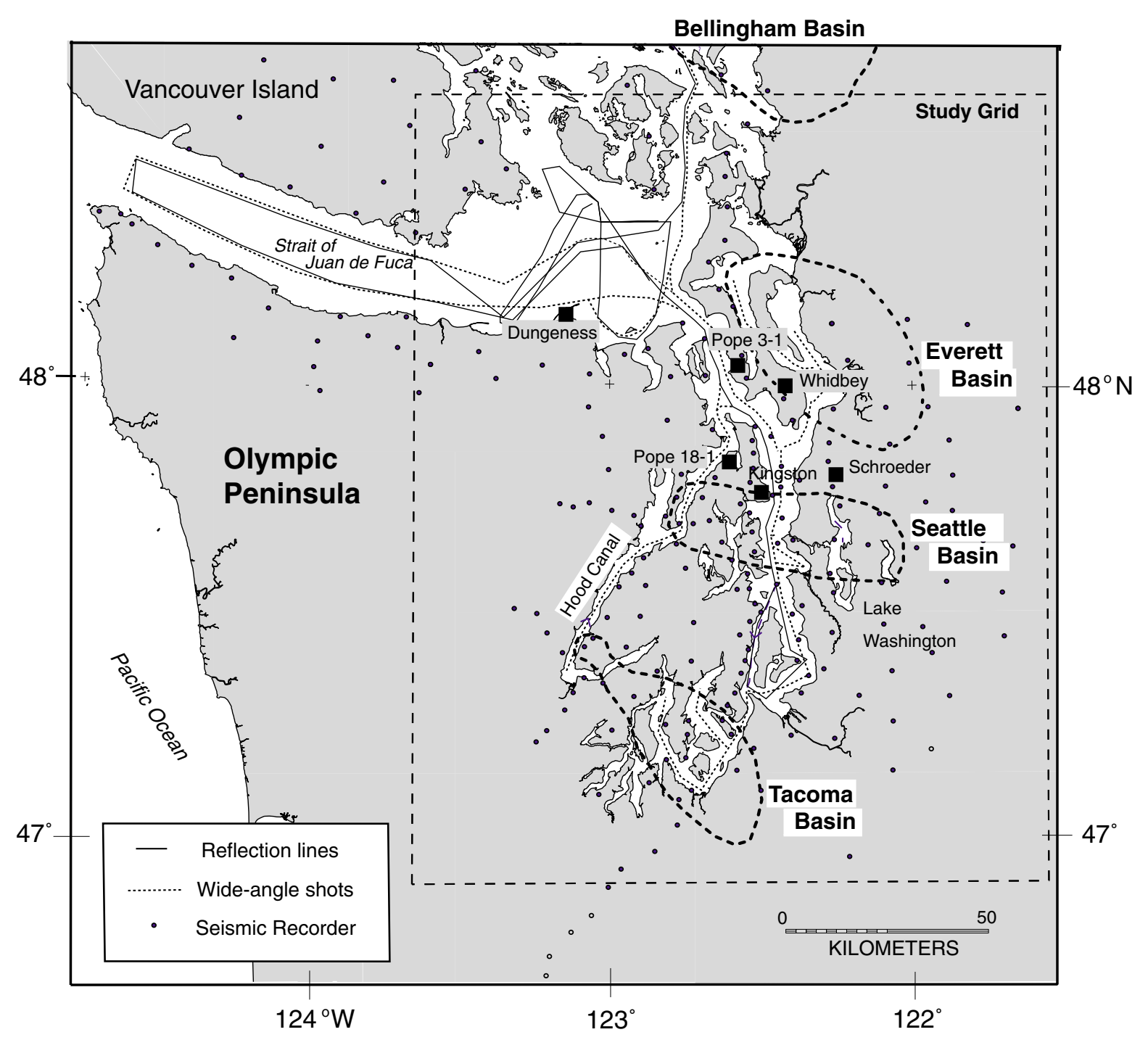

Figure 6. Location of Seismic Hazards Investigation in Puget Sound (SHIPS) seismographs (dots) and airgun tracks (dashed and solid lines) in northwest Washington. Black squares show locations of deep wells with sonic velocity logs examined in this study. 
on the sea floor and on land ( $\sim 5 \mathrm{~km}$ spacing). Traveltimes from refracted arrivals (crustal and upper mantle; Pg and Pn) were merged and inverted for velocity structure, and wideangle reflected arrivals (base of oceanic and continental crust; PmP) were forward modeled following the methods outlined by Hole and Zelt (1995) and Parsons and others (1996). The resulting velocity-structure model is shown in figure 7 . The root-mean-squared traveltime misfits for refracted arrivals were less than $0.1 \mathrm{~s}$, whereas misfits for all reflected arrivals were less than $0.15 \mathrm{~s}$. The velocity model was used as input for a Bouguer gravity model, and primary model features fit well with the observed gravity data. In the following discussion, various features will be described by their location in $\mathrm{km}$ from the model origin along the profile shown in figure 7.

\section{The Juan de Fuca Slab}

The descending Juan de Fuca slab was imaged by refractions and reflections from offshore air-gun blasts and reversing reflections recorded from chemical explosions on land. Seismic data coverage extends about $200 \mathrm{~km}$ offshore (fig. 7). Normal-thickness $(6 \mathrm{~km})$ subducting oceanic crust encounters the deformation front at about $\mathrm{km} 60$, where its dip increases from $0^{\circ}-2^{\circ}$ to $3^{\circ}-5^{\circ}$. Coincident multichannel reflection data show a series of landward-verging thrusts and fluid diapirs beginning at this point, implying low coupling stress along the interplate contact (Flueh and others, 1997). About $35 \mathrm{~km}$ offshore, the Juan de Fuca slab steepens from a $5^{\circ}-7^{\circ}$ dip to a $12^{\circ} \mathrm{dip}$, as determined from overlapping and reversed wideangle reflections from the base of oceanic crust recorded from land and marine sources (fig. 7). The observed $12^{\circ}$ dip, slightly steeper than the $9^{\circ}$ dip of Taber and Lewis (1986), persists to at least $50 \mathrm{~km}$ depth, $75 \mathrm{~km}$ east of the coastline (fig. 7). Slab earthquakes are located exclusively in the mantle part of the slab, counter to the global observations for young, warm slabs of Kirby and others (1996). Continuing the slab downward along a $12^{\circ}$ dip places it at rather shallow depths $(60-70 \mathrm{~km})$ beneath the Cascade arc volcanoes. Either the slab dip steepens eastward of where it reaches $50 \mathrm{~km}$ depth, or it is young and warm enough to produce arc volcanism at $60-70 \mathrm{~km}$ depths. Seismicity appears to coincide with the Moho boundary in figure $7 B$, but this location is a result of the choice of events to plot; events were restricted to M 4.0 above $25 \mathrm{~km}$ depth, but all events M 1.0 were allowed beneath $25 \mathrm{~km}$ depth to enable the best combination of highlighting zones of seismicity without obscuring the model with too many events. Smaller earthquakes are actually quite widely distributed throughout the continental crust (Stanley and others, 1996).

\section{The Accretionary Complex and Siletz Terrane}

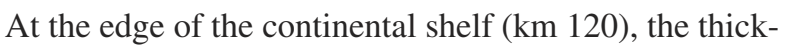
ness of accumulated sediment scraped from the descending plate reaches $7 \mathrm{~km}$. A 3-km-thick, low-velocity $(2.0-3.0 \mathrm{~km} / \mathrm{s})$ sequence fills a basin just inboard (east) of the continental slope edge. A basement high intervenes between this and a second, deeper ( $5 \mathrm{~km}$ of sub-3.0-km/s sedimentary rocks) basin at about $\mathrm{km} \mathrm{170.} \mathrm{This} \mathrm{part} \mathrm{of} \mathrm{the} \mathrm{shelf} \mathrm{and} \mathrm{upper} \mathrm{slope}$ is undergoing extension and collapse as shown by widespread normal faulting (McNeill and others, 1997).

Near the coastline lies the surface contact between accretionary rocks and the Siletz terrane, an accreted oceanic block of late Paleocene-early Eocene age that forms the basement to much of the Cascadia fore arc. Snavely and Wagner (1982) map this contact from well and seismic-reflection data as an east-dipping thrust that partially cuts a thin Quaternary unit about $1 \mathrm{~km}$ offshore near Greys Harbor ( $20 \mathrm{~km}$ north of the transect). The Siletz terrane is associated with a strong aeromagnetic signal along the profile where it crops out; this signal tapers off abruptly at the coastline (fig. 7A).

Projecting the Siletz-accretionary boundary to depth on the basis of the velocity model is problematic; outcrops of the Siletz terrane (Walsh and others, 1987) (fig. 2) correspond with the $5.0 \mathrm{~km} / \mathrm{s}$ contour in the model where it approaches the surface, and independent laboratory velocity measurements from the Siletz terrane taken from samples along the seismic profile show P-wave velocities between 4.5 and $5.2 \mathrm{~km} / \mathrm{s}$ for near-surface pressures. However, similar velocities would be expected for metamorphosed sedimentary rocks of the accretionary complex. High-velocity rocks $(6.5-7.7 \mathrm{~km} / \mathrm{s})$ are imaged in the lower continental crust beneath the surface outcrops of the Siletz volcanics in the Coast Ranges (km 190-230) and extend to the top of the descending slab, persisting to $\sim 20 \mathrm{~km}$ offshore. If these high-velocity rocks are interpreted as Siletz terrane, then the total thickness offshore is $20 \mathrm{~km}$, and the Siletz-accretionary boundary dips west from the coastline (fig. $7 B$ ). If, instead, the high-velocity lower crustal rocks offshore are more recently accreted oceanic crust, then the Siletz-accretionary boundary may dip east (Snavely and Wagner, 1982). There is a lateral velocity change at $\mathrm{km} 240$ in the model evidenced by a sudden shallowing of turning rays $(\mathrm{Pg})$ (fig. $7 C$ ), where highervelocity rocks $(>6.5 \mathrm{~km} / \mathrm{s})$ are found at shallower depth (10-11 $\mathrm{km}$ as compared with $17-18 \mathrm{~km}$ to the west). This shallowing of higher-velocity rocks to the east might result from an eastdipping Siletz boundary (fig. 7). The maximum thickness of the Siletz volcanics beneath the Coast Ranges could reach $35 \mathrm{~km}$ if they extend to the base of the crust (fig. 7B).

\section{The Cascadia Volcanic Arc and Back-Arc Crust}

The velocity model shown in figure 7 provides a cross section through the Cascade Range and the transition from the primarily collisional fore arc to the extensional back arc. A significant lateral change in upper-crustal velocity is observed across the Mount St. Helens seismic zone (km 340); the 6.5 $\mathrm{km} / \mathrm{s}$ contour is deeper on the east side of the seismic zone, whereas the $6.0 \mathrm{~km} / \mathrm{s}$ contour is shallower (fig. 7B). This boundary is interpreted as the eastern extent of the Siletz terrane and transition into Cascade arc crust, and the $6.0-6.5 \mathrm{~km} / \mathrm{s}$ zone beneath the volcanic arc is interpreted as silicic intrusive 
rocks on the basis of laboratory velocity measurements made on plutonic inclusions taken from the Mount St. Helens lava dome (Paine, 1982). This seismically determined position for the eastern extent of the Siletz terrane and transition into the Cascade arc is in reasonable agreement with the boundary modeled from gravity data (Finn, 1990). East of the Cascade Range, the combined thickness of Columbia River Basalt flows and subbasalt sedimentary units ranges from 6 to $8 \mathrm{~km}$, in reasonable agreement with the more detailed studies of Saltus (1993) and Jarchow and others (1994).

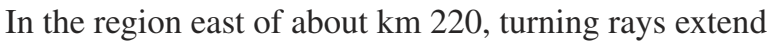
only to about $10-12 \mathrm{~km}$ depth. Thus crustal velocity beneath that depth was not directly measured by refracted waves but was instead modeled from arrivals reflected off the Moho
(PmP). East of $\mathrm{km} \mathrm{220,} \mathrm{turning} \mathrm{rays} \mathrm{were} \mathrm{refracted} \mathrm{at} \mathrm{about}$ $10-16 \mathrm{~km}$ depth along a horizon that represents rocks having $6.5 \mathrm{~km} / \mathrm{s}$ velocities; beneath the $6.5 \mathrm{~km} / \mathrm{s}$ contour, a velocity gradient from $6.5 \mathrm{~km} / \mathrm{s}$ to $7.0 \mathrm{~km} / \mathrm{s}$ is shown, and a crustmantle transition from 7.5 to $7.7 \mathrm{~km} / \mathrm{s}$ (fig. $7 B$ ). A number of crustal velocity gradients were tested, ranging from a uniform $6.5 \mathrm{~km} / \mathrm{s}$ crust to a $6.5-7.5 \mathrm{~km} / \mathrm{s}$ gradient, but did not introduce low-velocity zones. The $6.5-7.0 \mathrm{~km} / \mathrm{s}$ gradient produced the smallest traveltime residuals for continental PmP reflections (traveltime misfit to within $0.15 \mathrm{~s}$ ). The crust-mantle transition zone was required to fit reflection traveltimes from the descending slab beneath the crust and is consistent with low observed amplitudes of the continental PmP and Pn phases. The model shown in figure 7 assumes no lateral lower-crustal

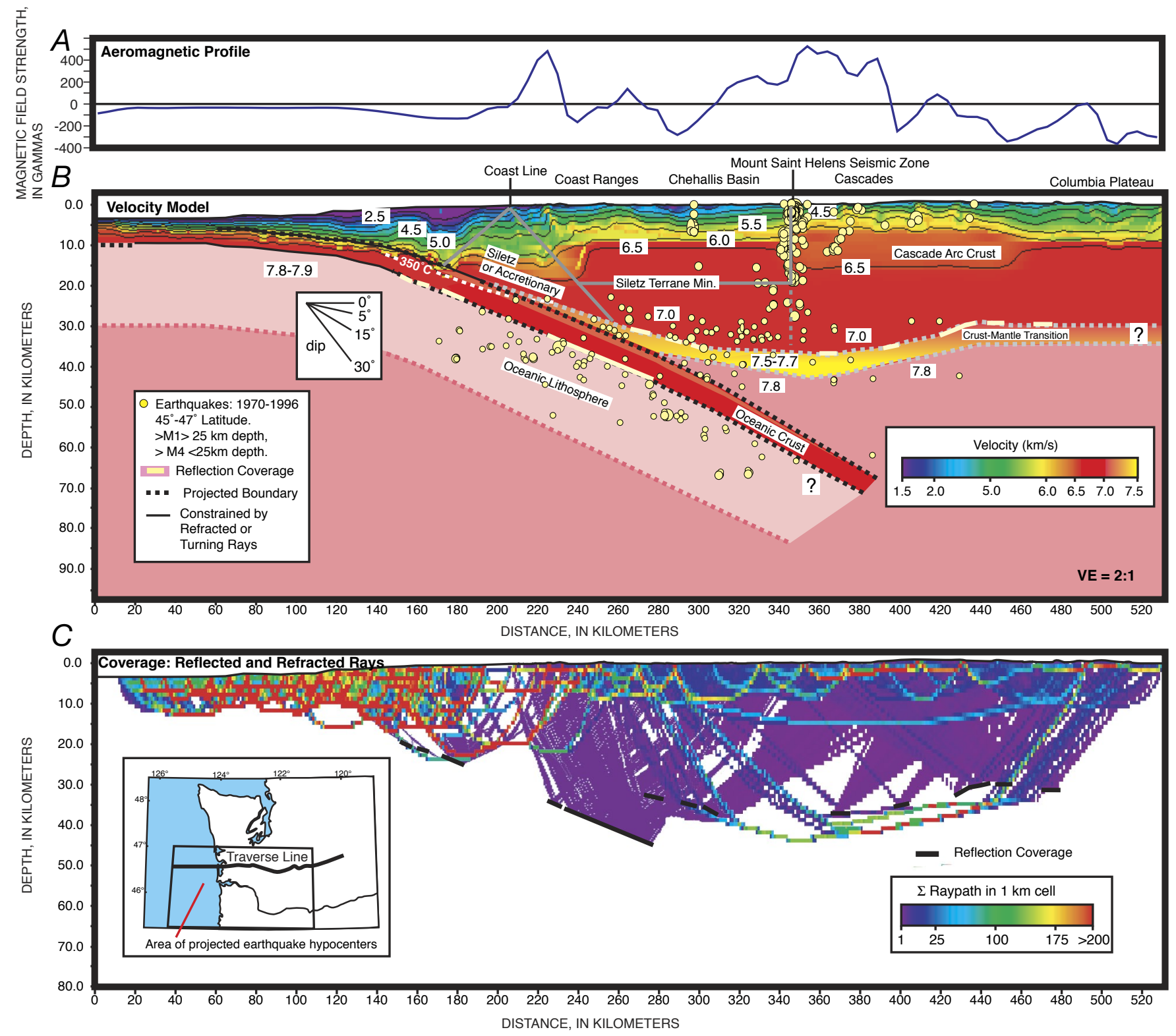

Figure 7. Velocity-structure model across Cascadia subduction zone and arc. A, Aeromagnetic profile coincident with the twodimensional seismic profile. $B$, Seismic velocity model across the Cascadia subduction zone and volcanic arc. Model features are discussed in text. $C$, Coverage diagram showing where the two-dimensional model is constrained. 
velocity contrasts; thus changes in crustal thickness could also be modeled by lateral velocity changes. Attempts to model a flat Moho by inserting lateral velocity contrasts led to arbitrary and in some cases impossible crustal velocities.

Continental crustal thickness increases from $\sim 20 \mathrm{~km}$ at the coastline to $\sim 30 \mathrm{~km}$ beneath the Coast Ranges and Chehalis basin. The crust is thickest (40-45 km) beneath the Cascade Range, where there is a broad root. The crust thins to about 30-38 km beneath the Columbia Plateau, slightly thinner than in the model of Catchings and Mooney (1988). A weak but measurable Pn phase was observed from three explosive sources and shows upper-mantle velocities of about $7.8 \mathrm{~km} / \mathrm{s}$ at the base of the crust-mantle gradient zone (fig. 7). Upper mantle velocities were measured at $7.8-7.9 \mathrm{~km} / \mathrm{s}$ beneath the oceanic crust offshore.

\section{Implications of the Two-Dimensional Model for Earthquake Hazards}

The image of the subduction process emerging from the model is one of a young ( 10 m.y. old) and buoyant (Heaton and Hartzell, 1987), shallow-dipping (12 ${ }^{\circ}$ ) Juan de Fuca Plate that appears to bend as a result of overriding contact with rocks accreted to the North American Plate. This observed subduction geometry concentrates the potentially locked interplate contact offshore; the shallow dip broadens the zone out to the deformation front ( $\sim 120 \mathrm{~km}$ offshore), and the steeper part of the slab encounters $350^{\circ} \mathrm{C}$ temperatures at about $25-30 \mathrm{~km}$ depth $\left(350^{\circ} \mathrm{C}\right.$ is thought to be the temperature at which stable sliding begins; Hyndman and Wang, 1993) near the coastline (fig. 7B). A similar seismogenic depth limit was observed beneath Mexico, where the comparably young Cocos Plate subducts (Tichelaar and Ruff, 1993). The interplate contact above the approximate depth of the $350^{\circ} \mathrm{C}$ contour is devoid of even very small earthquakes (fig. $7 B$ ). The low coupling stress along the interplate contact-as inferred from the presence of landwarddipping thrusts, high pore-fluid pressures (Flueh and others, 1997), and low frictional heating-implies that on the time scale of the seismic cycle, earthquakes are likely to be associated with a complete stress drop (Wang and others, 1995).

In the upper plate, the strong, mafic Siletz terrane rocks apparently play an important role in delimiting earthquakes along their eastern boundary. The correspondence between the eastern edge of the Siletz block and the onset of seismicity in the Mount St. Helens zone (fig. 7B) may result from clockwise rotation (determined from paleomagnetics) of the coherent Siletz block that concentrates seismicity at its edges and limits internal seismogenic deformation (Wells, 1990; England and Wells, 1991; Tréhu and others, 1994; Stanley and others, 1996). At present, the western edge of the Siletz terrane is not a focus of seismic activity. Judging from the apparent influence of this boundary on accretionary-complex deformation offshore of Oregon, where the western edge is overlain by short-wavelength folds and faults (Tréhu and others, 1995), it is possible that an analysis of sedimentary structures in this region would reveal similar effects. However, the details of this process likely depend strongly on the dip of Siletz terrane and on the nature of the high velocity material at depth beneath the shelf (Byrne and others, 1993).

\section{Traveltime Inversion for Three- Dimensional Upper Crustal Velocity Structure of Western Washington}

Eocene-age volcanic rocks underlie most of the fore arc in Oregon and Washington and are called the Crescent Formation in Washington and the Siletz River Volcanics in Oregon (Snavely and others, 1968). Because of its mafic composition, this fore arc terrane, also known as the Siletz terrane, or "Siletzia" (Irving, 1979), is thought to be composed of strong crustal blocks that play an important role in fore-arc deformation (Magill and others, 1981; Wells and Coe, 1985; Wells and Weaver, 1993; Tréhu and others, 1994; Stanley and others, 1996). Arc-parallel migration of these blocks in response to oblique subduction focuses upper crustal deformation and seismicity along block boundaries, which may be potential sources of earthquakes (Wells and others, 1998).

Along much of the Cascadia subduction margin, accreted sedimentary rocks are thrust beneath Siletzia along a major terrane-boundary fault presumed to dip eastward beneath the Coast Range (Tabor and Cady, 1978; Snavely, 1987). Though this boundary is an important locus of strain-accommodation, it is presently seismically quiet and its earthquake potential is unknown. In the southwest Washington arc, however, the northwest-trending Mount St. Helens and west Rainier seismic zones are thought to mark the eastern extent of Siletzia (e.g. Stanley and others, 1996; Parsons and others, 1998).

The two-dimensional cross-section velocity profile, while providing a relatively high-resolution image of the velocity structure across the margin, is only a single cross section and cannot constrain the dip of the boundary between Siletzia and the accretionary complex because of the wide range of possible velocities in the metamorphosed accreted rocks at shallow depths. Possible interpretations of the velocity structure include landward or seaward dips (fig. 7). Multiple cross sections tied to the near-surface geology offer a better chance to constrain the dip. Thus, one of the goals for conducting the three-dimensional study was to get a greater variety of raypaths through the accretionary and Siletz terrane rocks than were recorded along the two-dimensional profile.

The Cascadia subduction margin shows many alongstrike tectonic variations, including accretionary-prism width, seismicity rate, and volcanic production (fig. 1). Because of the important role that the Siletz terrane apparently plays in shaping the margin, defining the along-strike variation of its boundaries may provide some of the constraints needed to understand variations in the nature of 
deformation and earthquake potential along major upper plate structures in the Washington fore arc.

\section{Traveltime Data}

A total of 69,251 P-wave first-arrival traveltimes from controlled and earthquake sources were included in the velocity modeling. As can be seen in figure 1, coastal Washington is seismically quiet; thus very few earthquake-source arrival times were available for the coastal regions. The majority $(67,898)$ of the traveltimes were from controlled sources, with only 1,353 arrivals used from earthquakes (fig. 8). There are some advantages in applying primarily controlled sources; two of the free parameters of a simultaneous inversion, source location and origin time, are known, reducing uncertainties. However, all the controlled sources were located at the surface, limiting the deeper coverage that would result had more earthquake sources been available. For the velocity inversion, only first arrivals were included, either $\mathrm{Pg}$, the crustal refracted phase, or Pn, the upper-mantle refracted phase. All controlled-source seismic data were hand picked on a computer screen display; the estimated picking errors are $100 \mathrm{~ms}$ (one cycle at $10 \mathrm{~Hz}$ ). Data examples are shown in figures 4 and 5.

The limited set of earthquake traveltimes came from two data sets. The first group of earthquake-source traveltimes was recorded by the temporary array deployed during April and May of 1996 (figs. 3,8). During this period 300 earthquakes were recorded, distributed across western Washington (green stars on fig. 3) and including the $\mathrm{M}=5.4$ Duvall earthquake that occurred $\sim 30 \mathrm{~km}$ east of Seattle and many of its aftershocks. Only the vertical channel was recorded on the temporary network. A total of 267 high-quality arrivals that could be used in the velocity inversion were recorded on the 44 distributed stations. A high-quality event was defined as one recorded by at least five permanent network stations from the Pacific Northwest Seismic Network (PNSN), and with a root mean square (RMS) error in location less than $2 \mathrm{~km}$.

The second group of earthquake arrivals came from selected PNSN permanent stations that were located near the coast (pink triangles on fig. 3). Data from a small group of well-located events (1995-1997, $\mathrm{M} \geq 2.0$, yellow stars on fig.

\section{Temporary Network Earthquake P-wave Data: Olympic National Park}

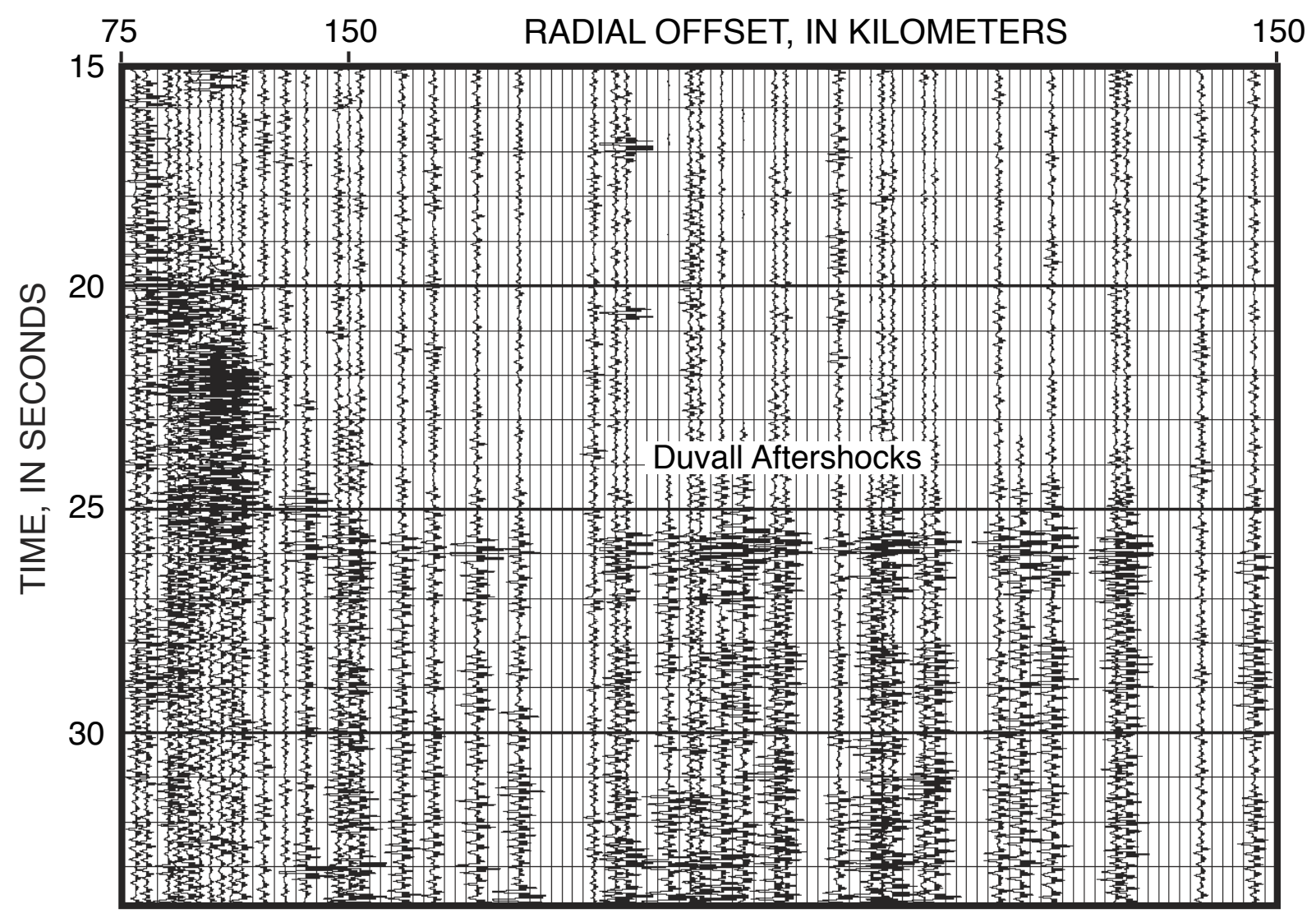

Figure 8. An example of local earthquake data collected on the vertical component, showing the Pg phase. Because many of the events recorded are aftershocks from the Duvall earthquake, they are not plotted at an equal offset scale; if they were, most of the Duvall events would be plotted on top of each other. Instead, the events are plotted at a variable offset scale. 
3) were recorded at 12 sites. The earthquake source regions in western Washington are dominantly the Puget Sound and Cascade Range areas; enough events were used to get a reasonably uniform sampling of travel paths through the three-dimensional model without clustering too many events in specific locations. The goal was to solve for the broad-scale ( 25 to $50 \mathrm{~km}$ ) velocity structure; therefore, adding large numbers of coincident sources would have added to computation times without significantly improving resolution.

\section{Velocity Modeling Methods}

The three-dimensional tomographic technique of Hole (1992) was modified to simultaneously invert for velocity, hypocenters, and origin times (hypocenters and origin times only for the earthquake data). This technique applies a finitedifference solution to the eikonal equation (Vidale, 1990; updated by Hole and Zelt, 1995) to calculate first arrival times through a gridded slowness model. An iterative nonlinear inversion is performed as a backprojection along raypaths determined from the forward modeling step.

A larger three-dimensional volume was modeled than that containing the targeted coastal region where the Siletz terrane meets accreted sedimentary rocks so that important seismic source regions could be included, such as the offshore airguns and the seismically active Puget Sound region (fig. 3). The choice of a large model volume created regions of relatively sparse ray coverage. Therefore, as always, the choice of a starting model was important in guiding the final model. A smoothed version of the detailed two-dimensional cross-section model was extrapolated parallel to the margin to generate a three-dimensional starting model. In many cases headwaves were observed from the dipping Juan de Fuca slab as first arrivals from the offshore airguns; thus, having the approximately correct slab structure in the starting model allowed for the proper treatment of these arrivals. Starting models were discretized into grids of $2.5-\mathrm{km}$ cells; relatively small grid cells were used to ensure accurate calculation of ray paths along short source-receiver offsets.

Traveltime picks were compiled for controlled (figs. 4, 5) and earthquake (fig. 8) sources for each receiver as a function of their three-dimensional spatial source locations and then inverted for three-dimensional velocity structure. Initial hypocenter locations and origin times of earthquakes were input as determined by the PNSN. A spatial smoothing filter was applied to the models between velocity and source-parameter iterations. Early iterations were conducted that applied very broad smoothing filters (up to $100 \mathrm{~km}$ ) and limited source-receiver offset ranges to solve the shallowest parts of the velocity model first. Subsequent iterations were conducted that included greater source-receiver offsets and progressively smaller smoothing filters.

The earthquakes used in this study were initially located with a simple vertical (one-dimensional) velocity model; thus a degree of coupling between hypocenter location and the velocity structure derived from earthquake traveltimes is unavoidable and could cause significant errors in the resolved velocity models (Thurber, 1993), especially in areas where controlled sources were absent. To reduce such errors, hypocenters and origin times were relocated while controlled-source locations and times were held fixed. The events were relocated between velocity iterations (mean relocation was $0.28 \mathrm{~km}$ ). See Hole (1992) for full details on the traveltime inversion algorithm.

\section{Resolution}

Resolution in tomography depends on three properties of the problem - the signal band width, the source-receiver distribution, and the velocity structure itself. For crustal-scale experiments the signal wavelengths are typically much smaller than the gaps in raypath coverage (as they are in this study, 2-20 Hz). Three approaches are usually adopted to investigate resolution in tomographic problems. The simplest is a hitcount analysis. In this analysis, the number of rays sampling a given cell are examined to identify regions of good coverage and poor coverage. The second approach to resolution analysis is the construction of synthetic tests using the data distribution (Humphreys and Clayton, 1988). The synthetic test may be an attempt to construct point-spread functions, or it may be an attempt to reconstruct the major features of the model simultaneously. The third common method of resolution analysis is the use of the resolution matrix of linear inverse theory. Typically the diagonals of the resolution matrix are displayed, and a certain value is chosen to indicate good resolution. The resolution matrix is a construct well suited to the study of linear problems. However, the extension of this tool to nonlinear problems is always questionable, particularly when the solution is approached iteratively (Shaw and Orcutt, 1985).

Each of the above resolution diagnostics depends on the velocity structure used to construct the resolution measures. Quantitatively connecting a hit count, synthetic test, or resolution matrix with the actual accuracy of the reconstructed image is not straightforward. A combination of these resolution indicators can provide some intuition into the resolving power of the data. A backprojection was used, thus no formal resolution matrix was calculated. Instead, a hit count is shown to illustrate the seismic ray coverage and checkerboard tests used to estimate the degree of uniqueness of the solution. The estimates of spatial and relative velocity resolution based on the checkerboard tests vary with depth, and they are thus reported individually for slices from the three-dimensional velocity model. The checkerboard tests were conducted by calculating synthetic traveltime picks between all the source and receiver positions through a model of vertical columns, $50 \mathrm{~km}$ by $50 \mathrm{~km}$, each with alternating increasing velocity gradients that were $0.5 \mathrm{~km} / \mathrm{s}$ different at all depths (figs. 9-13). Additionally, vertical gradients at various depths were alternated (to create checkerboards in cross section) to test the resolution of horizontal velocity boundaries. Only the resolution of increasing velocity gradients within column elements were tested. 
A Seismic Velocity of Western Washington Upper Crust: Depth=2.5 km

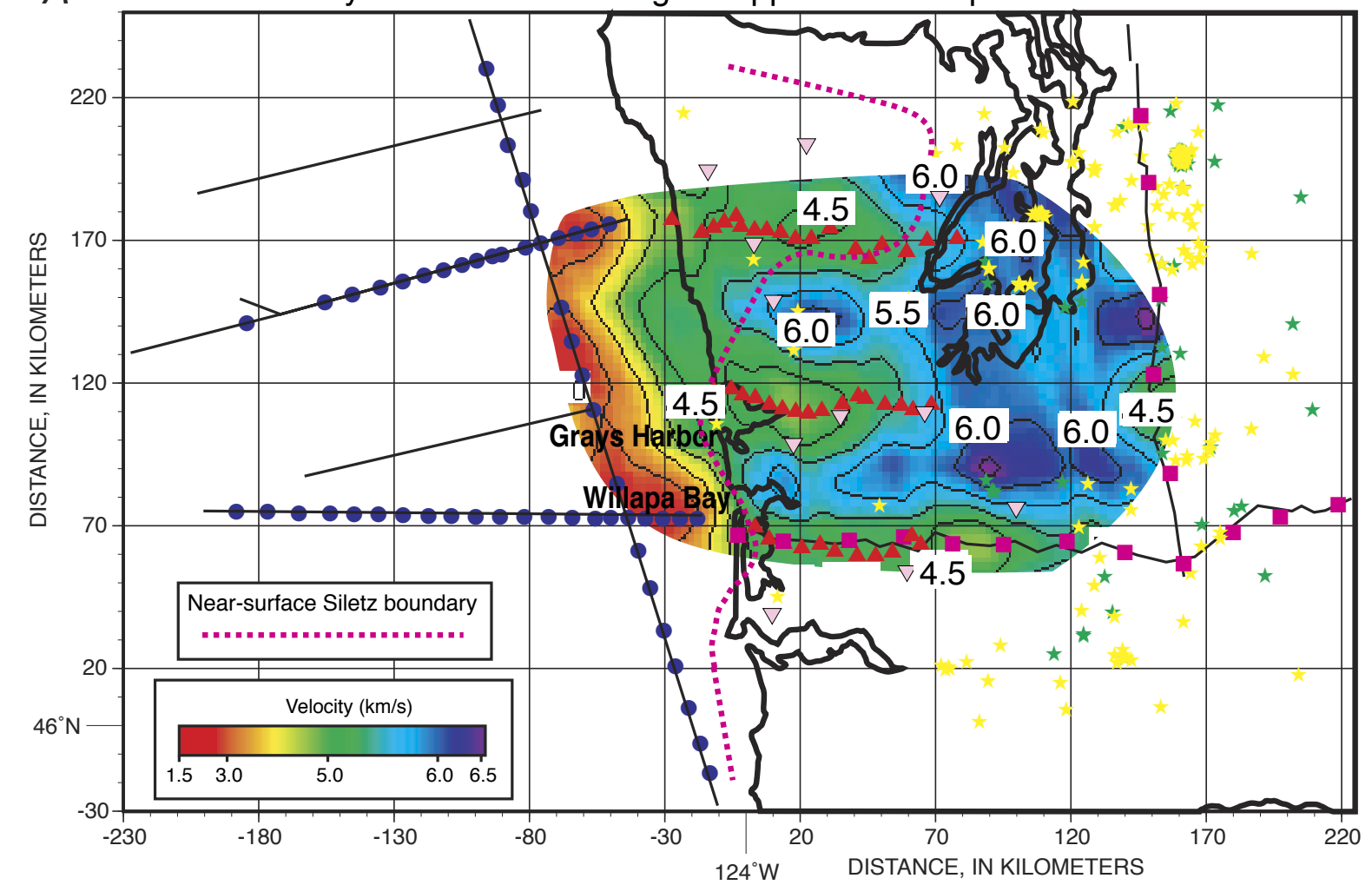

Ray Coverage

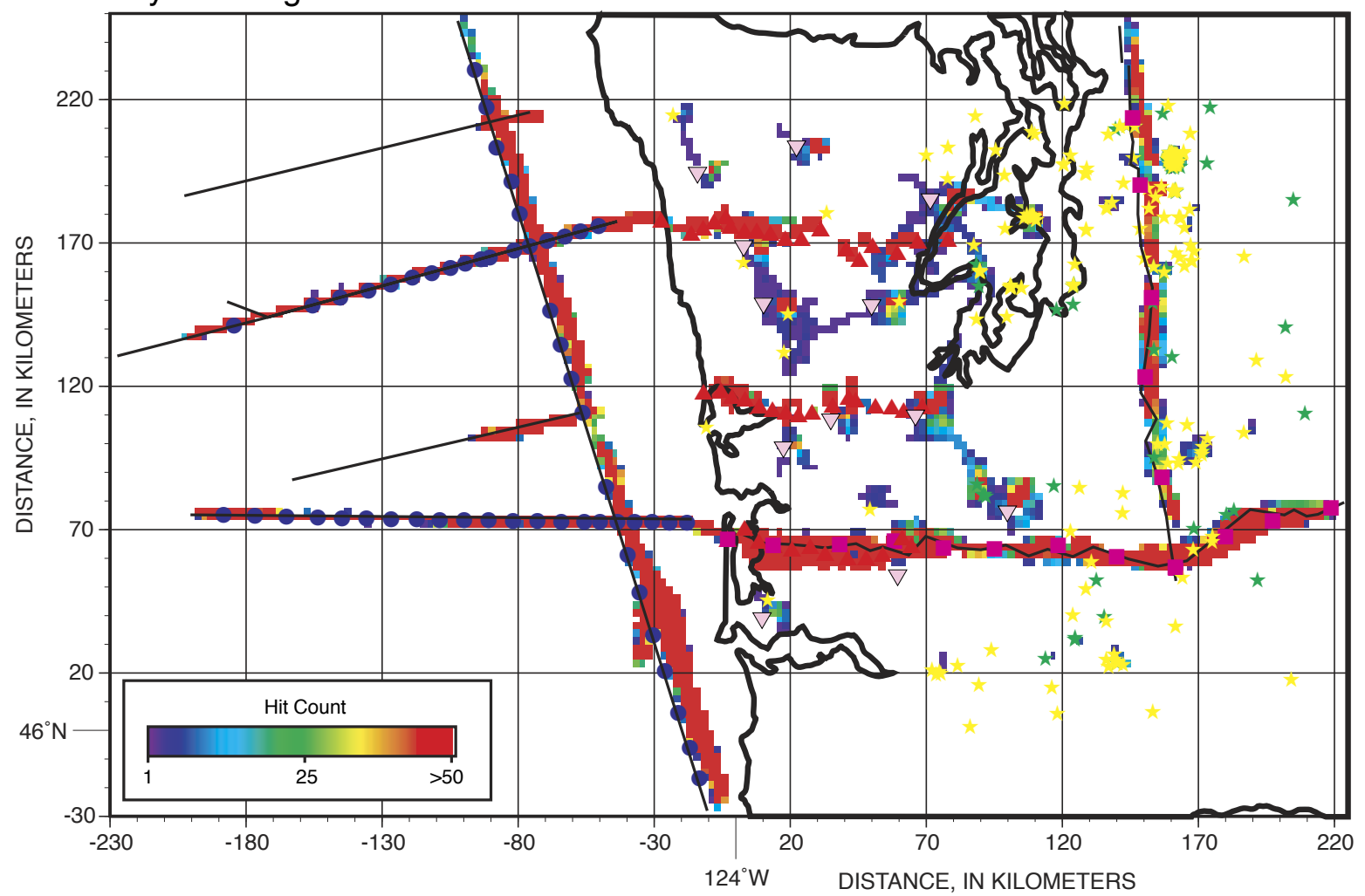

Figure 9. Velocity model slice at 2.5-km depth. Full discussion of the model slice and resolution test are in the text. See figure 3 for explanation of symbols. $A$, Horizontal slice from the three-dimensional velocity model volume taken from $2.5 \mathrm{~km}$ below sea level. $B$, Results from a checkerboard resolution test, with the recovered model shown above the input model. 


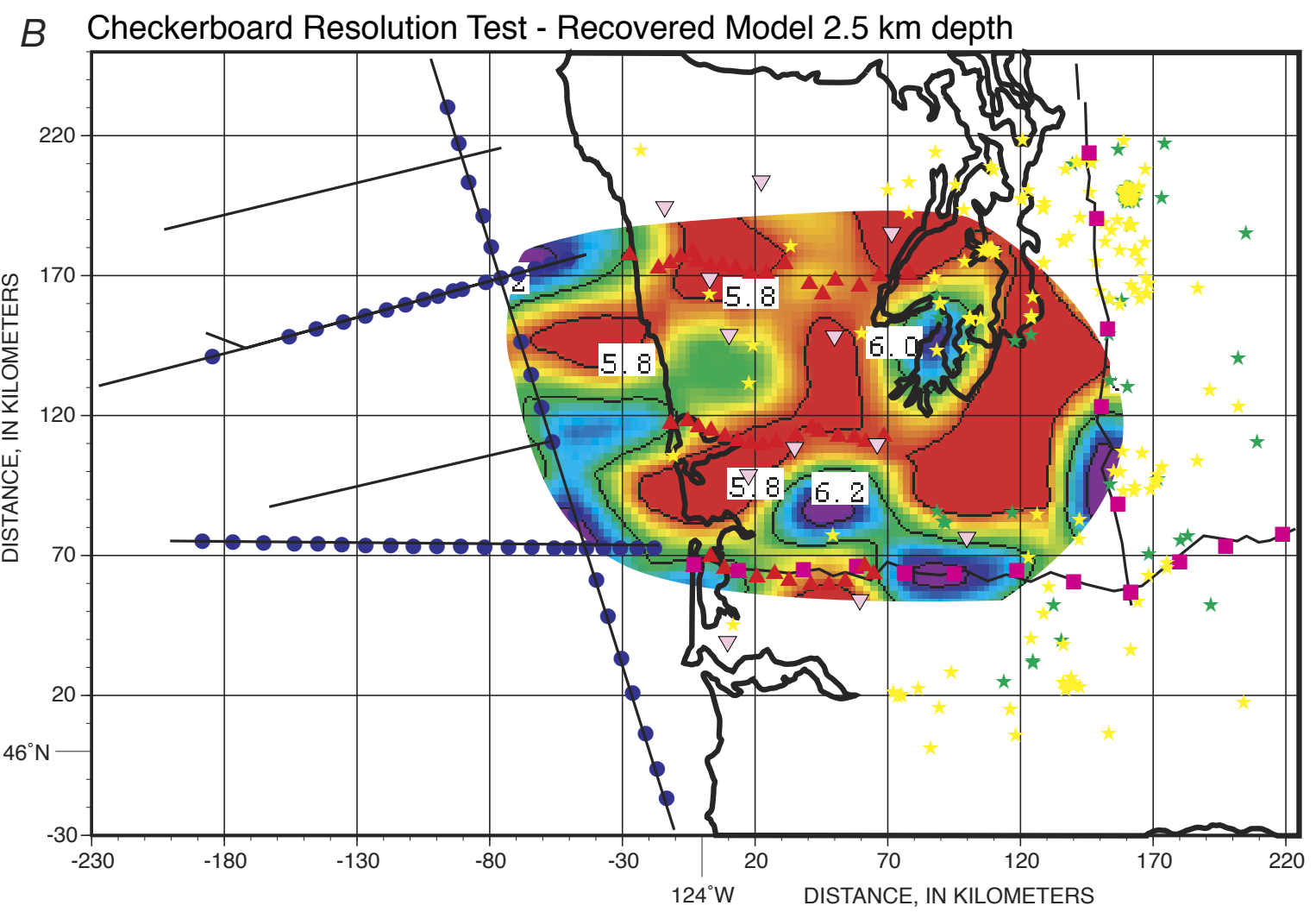

Actual Model

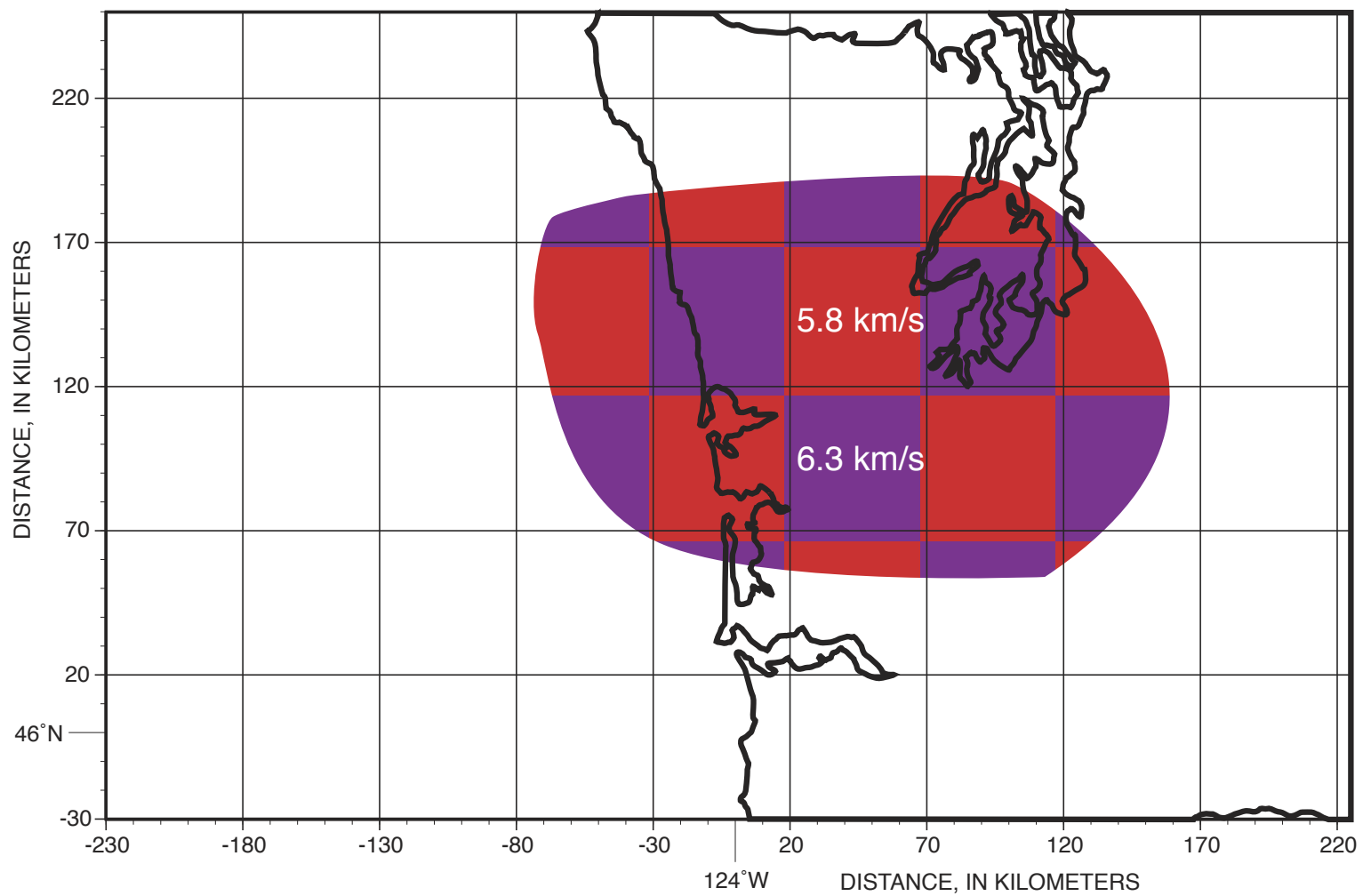

Figure 9.-Continued. 
A Seismic Velocity of Western Washington Upper Crust: Depth=7.5 km

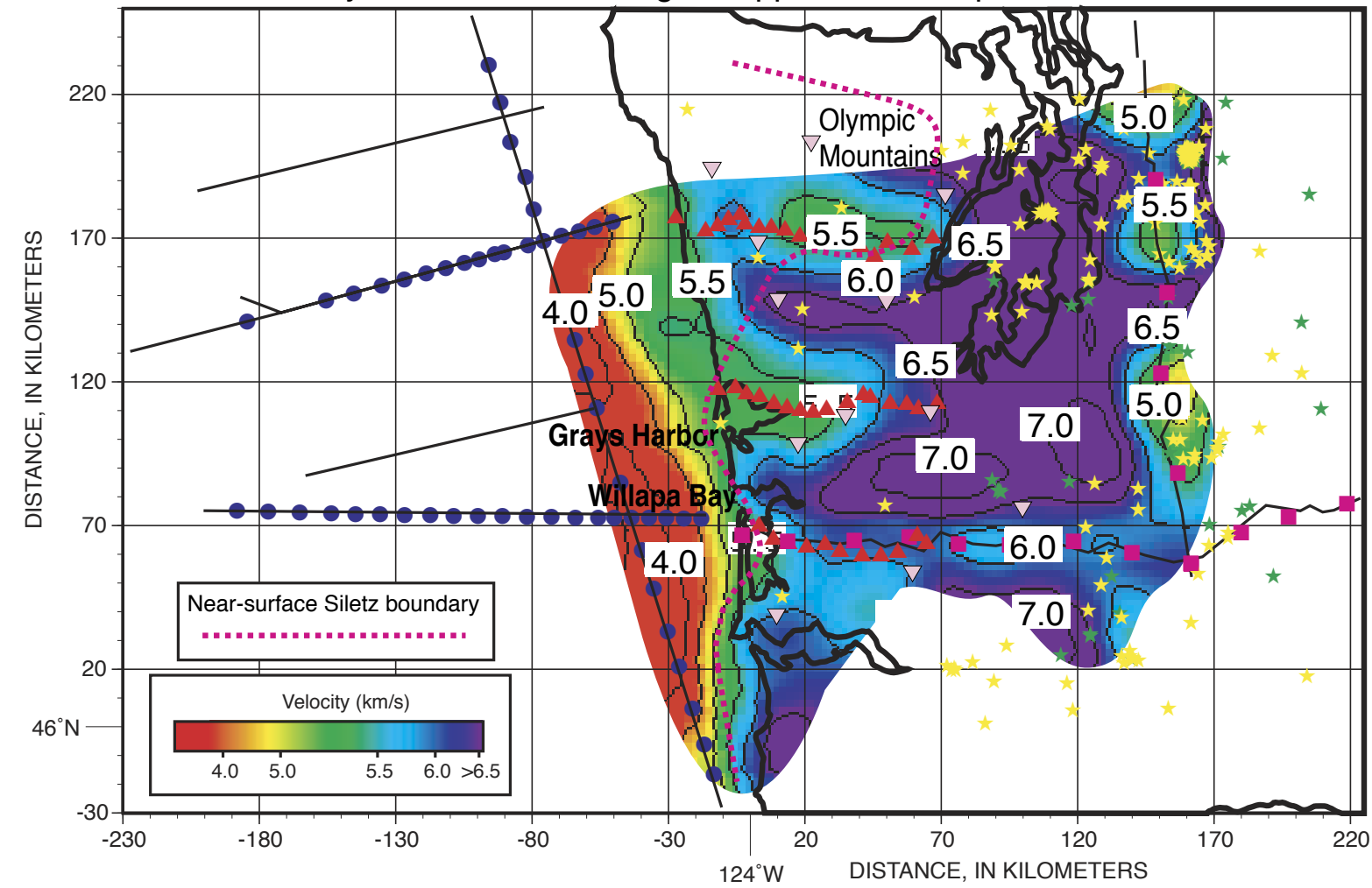

Ray Coverage

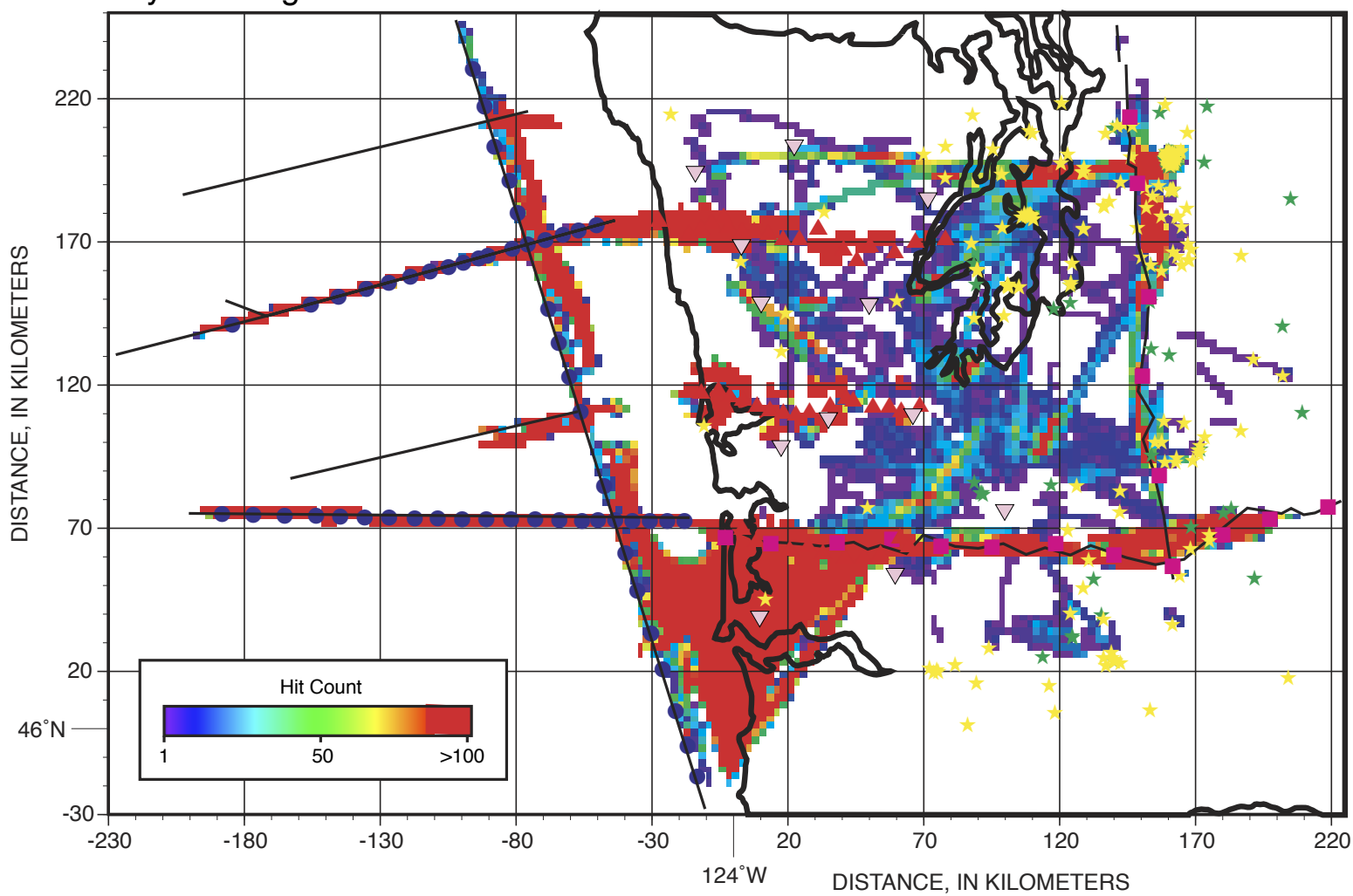

Figure 10. Velocity model slice at 7.5-km depth. Full discussion of the model slice and resolution test are in the text. See figure 3 for explanation of symbols. $A$, Horizontal slice from the three-dimensional velocity model volume taken from $7.5 \mathrm{~km}$ below sea level. $B$, Results from a checkerboard resolution test, with the recovered model shown above the input model. 


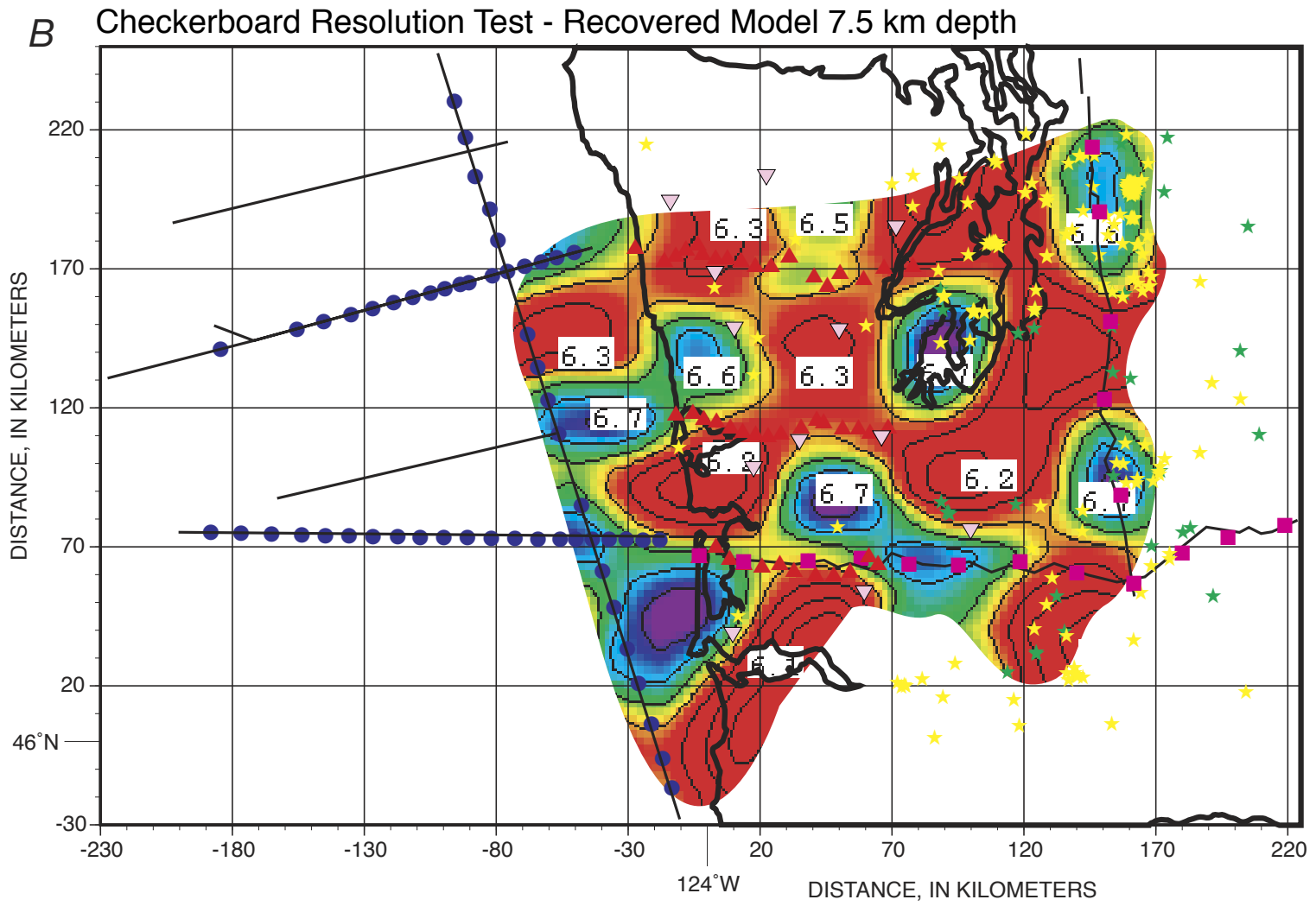

Actual Model

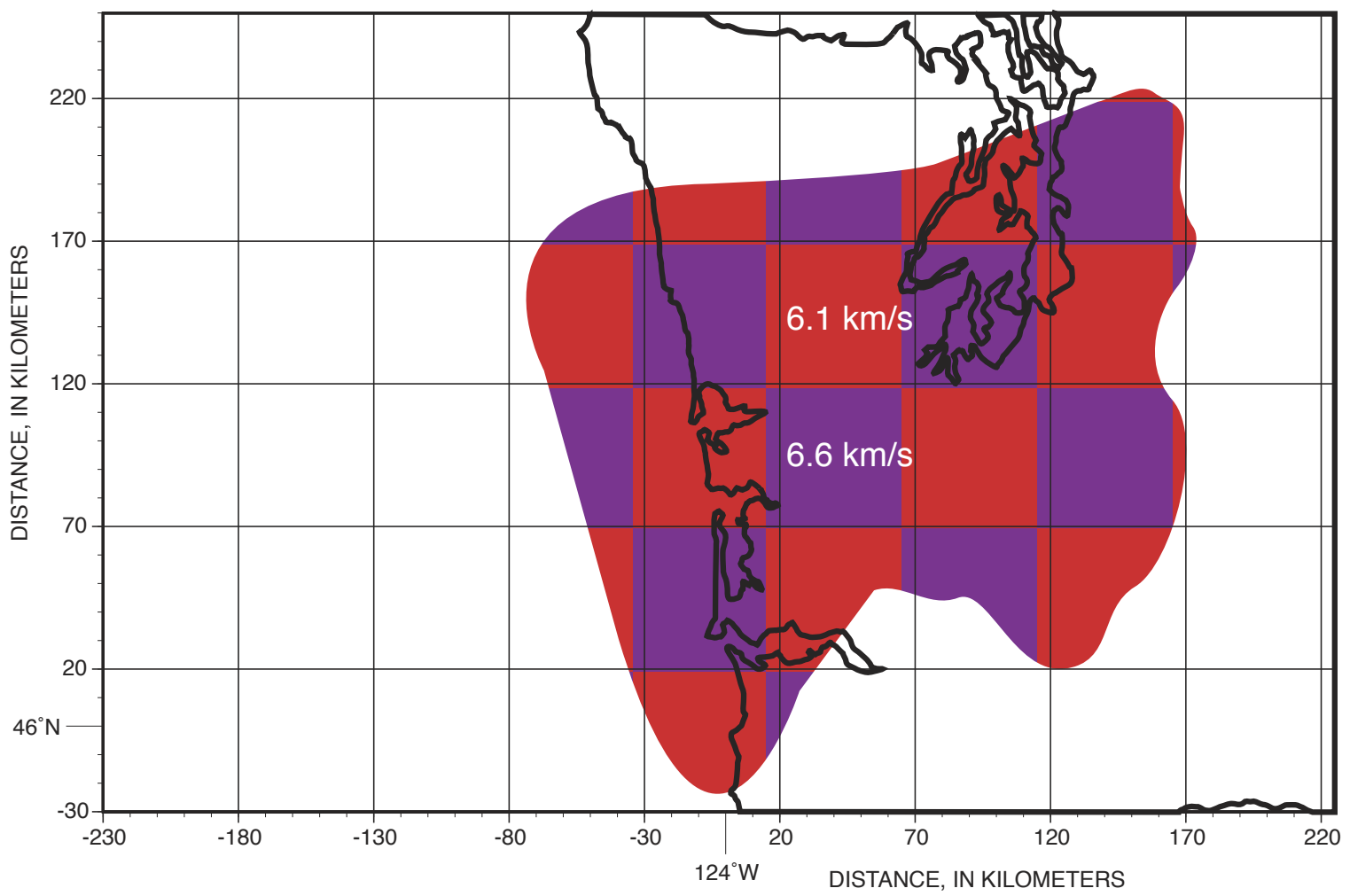

Figure 10.-Continued. 
A Seismic Velocity of Western Washington Upper Crust: Depth=12.5 km
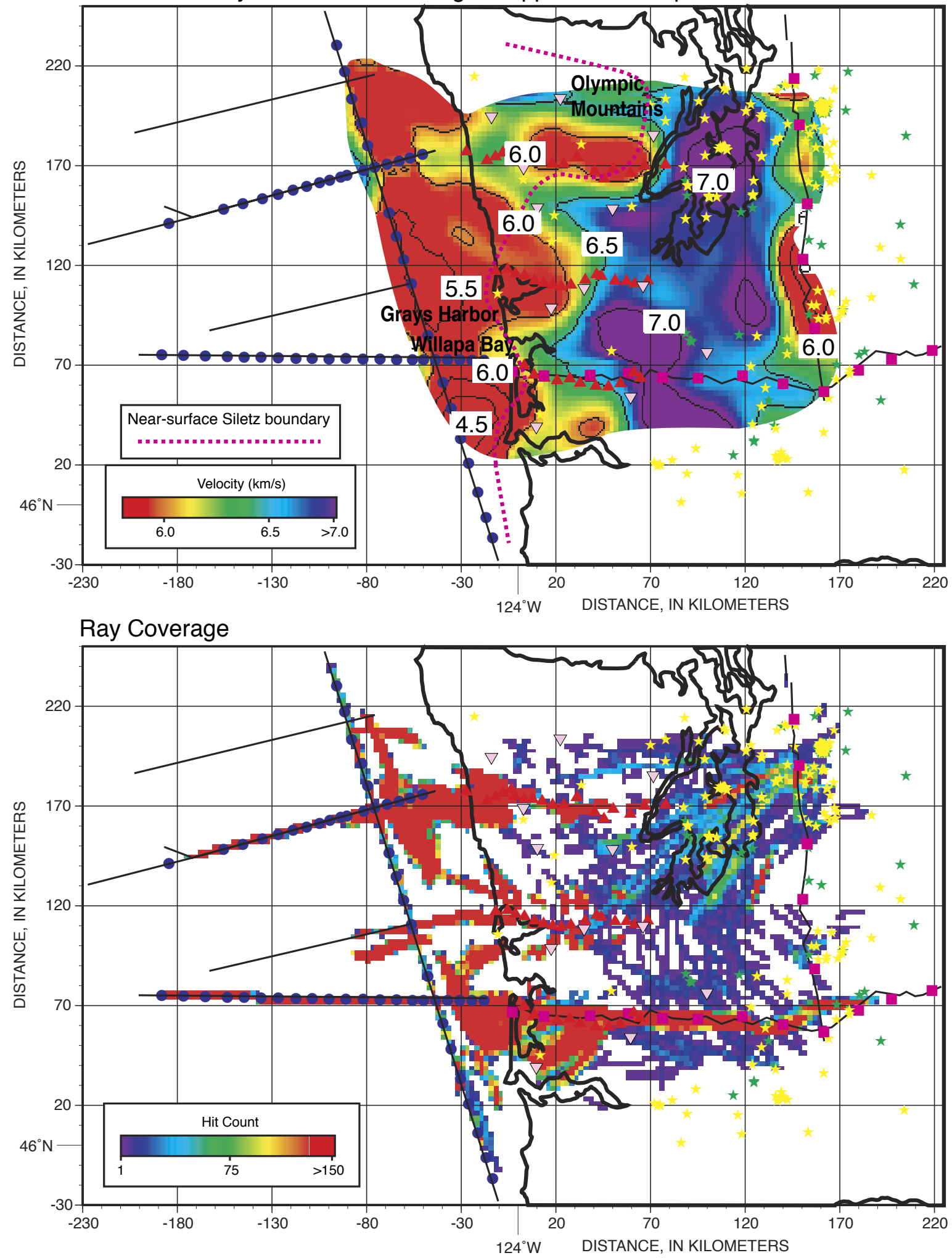

Figure 11. Velocity model slice at $12.5-\mathrm{km}$ depth. Full discussion of the model slice and resolution test are in the text. See figure 3 for explanation of symbols. $A$, Horizontal slice from the three-dimensional velocity model volume taken from $12.5 \mathrm{~km}$ below sea level. $B$, Results from a checkerboard resolution test, with the recovered model shown above the input model. 


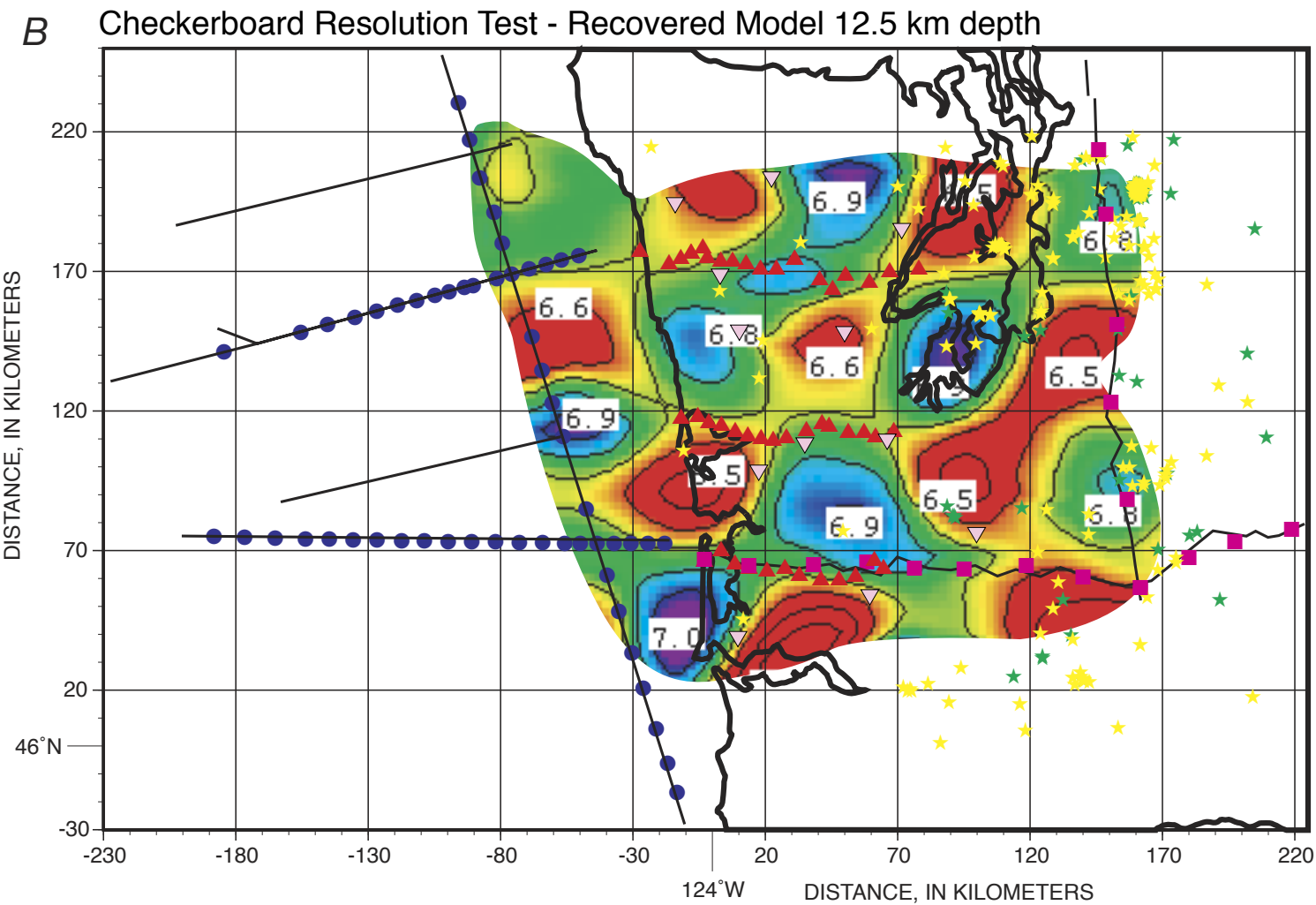

Actual Model

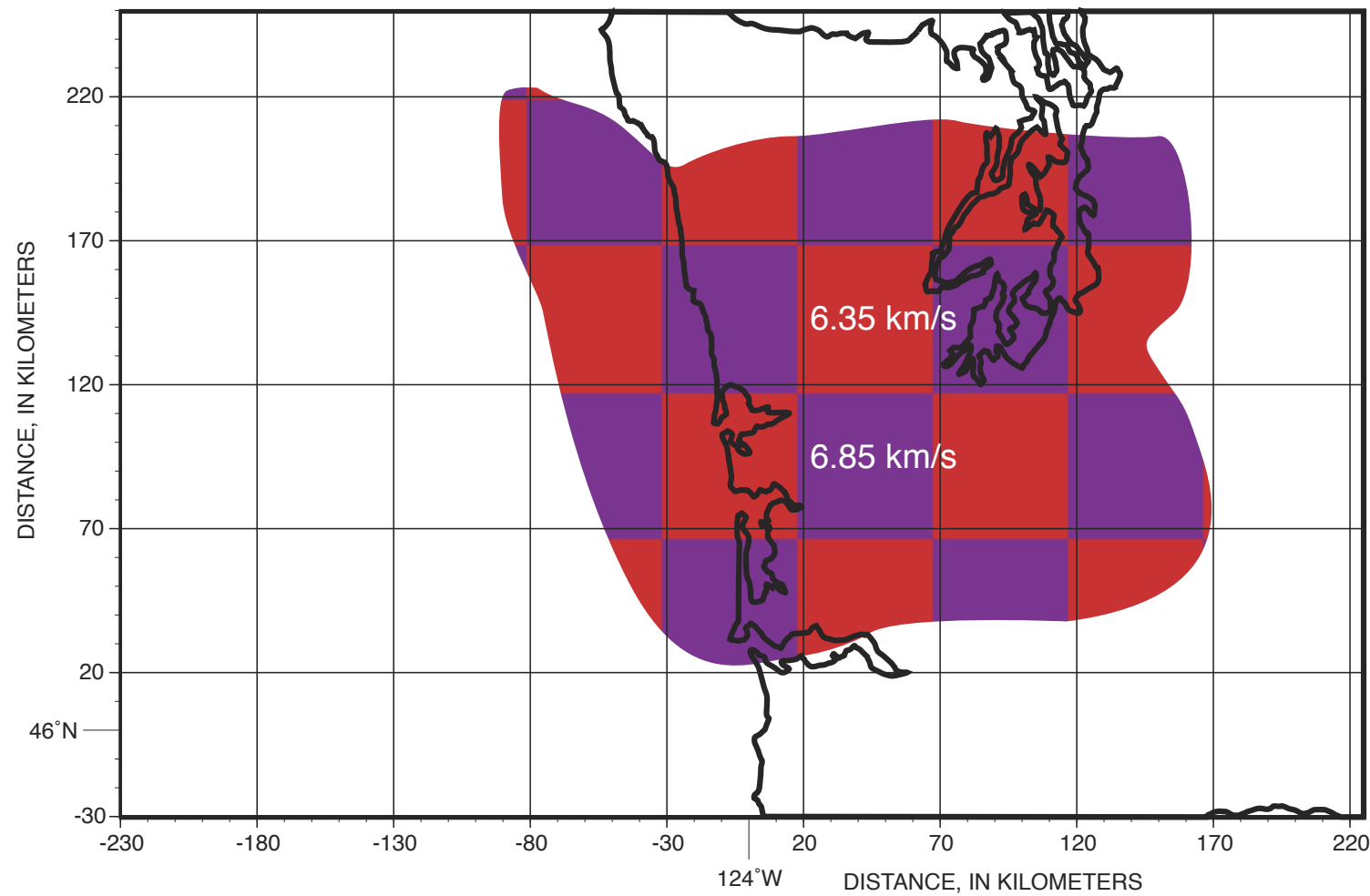

Figure 11.-Continued. 
A Seismic Velocity of Western Washington Upper Crust: Depth=17.5 km

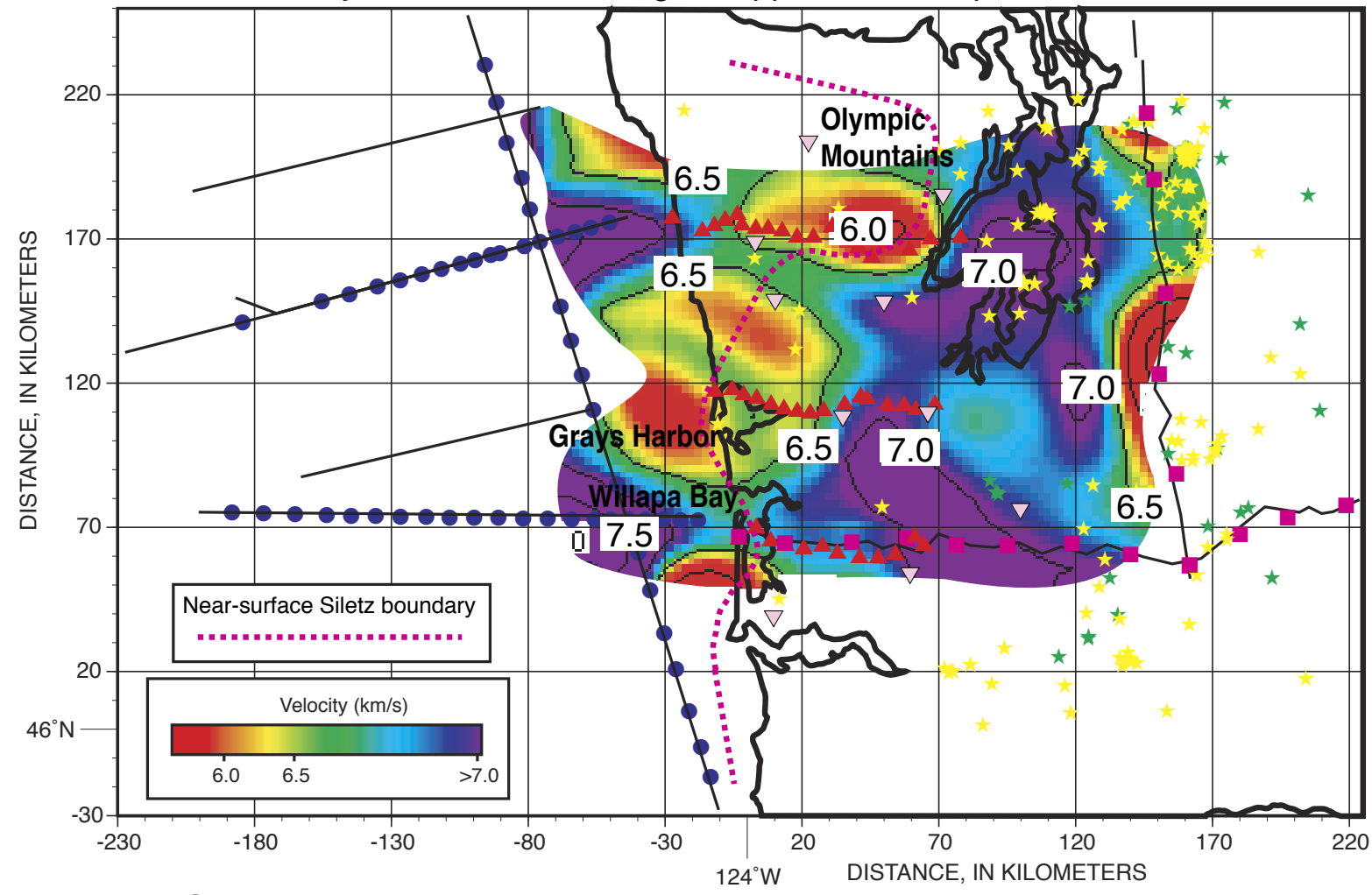

Ray Coverage

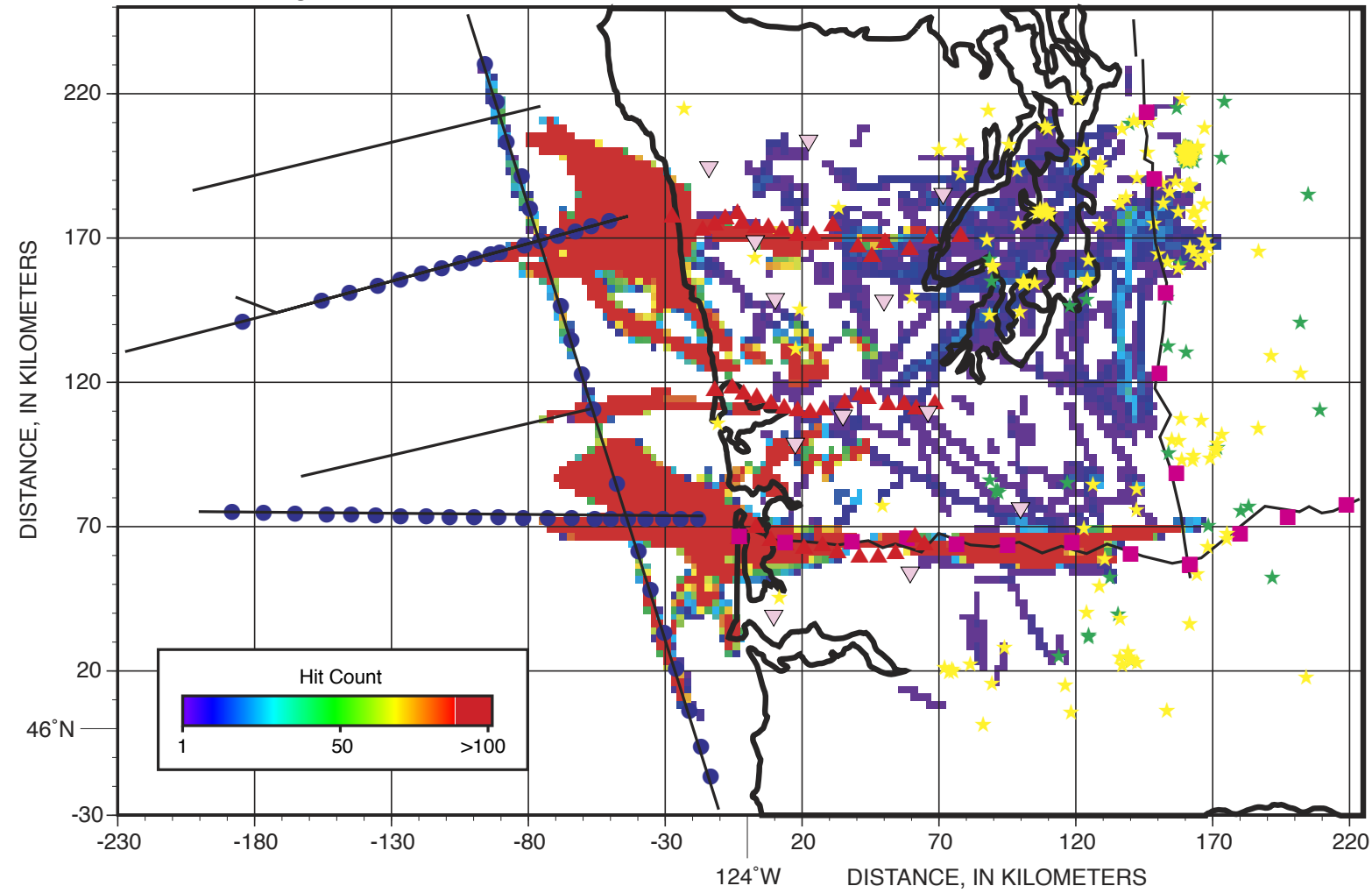

Figure 12. Velocity model slice at $17.5-\mathrm{km}$ depth. Full discussion of the model slice and resolution test are in the text. See figure 3 for explanation of symbols. $A$, Horizontal slice from the three-dimensional velocity model volume taken from $17.5 \mathrm{~km}$ below sea level. $B$, Results from a checkerboard resolution test, with the recovered model shown above the input model. 

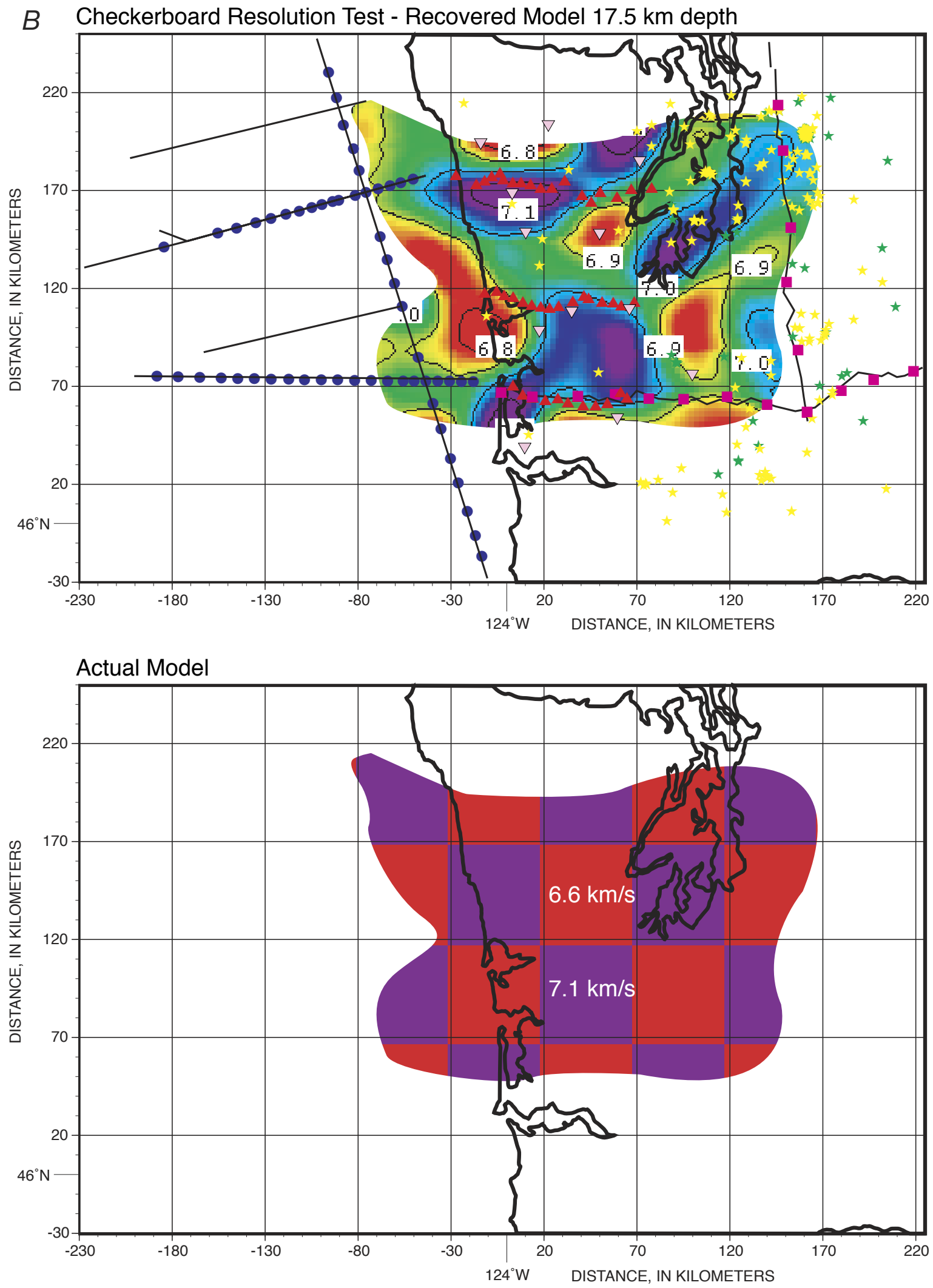

Figure 12.-Continued. 
A Seismic Velocity of Western Washington Upper Crust: Depth=22.5 km

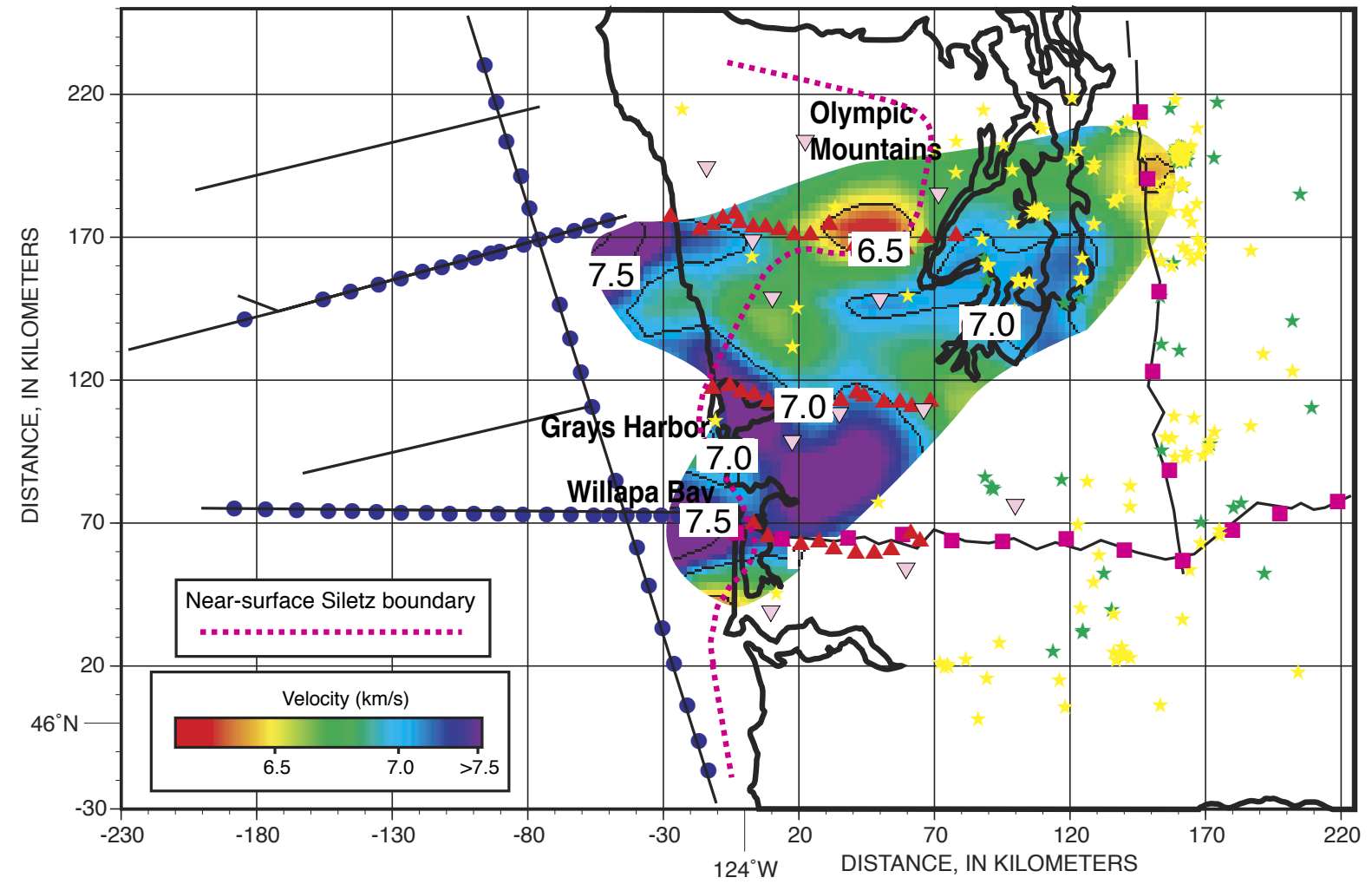

Ray Coverage

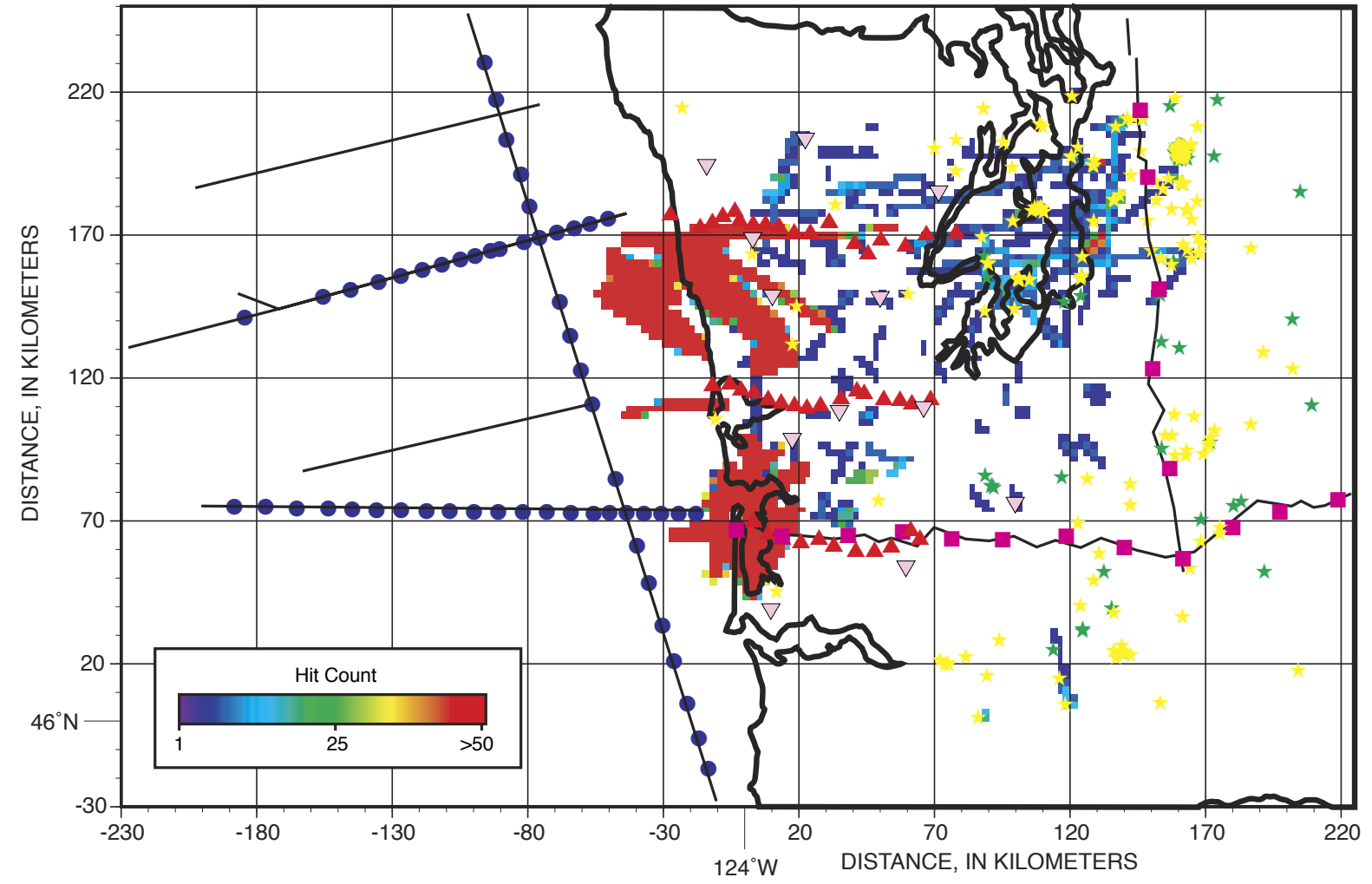

Figure 13. Velocity model slice at 22.5-km depth. Full discussion of the model slice and resolution test are in the text. See figure 3 for explanation of symbols. A, Horizontal slice from the three-dimensional velocity model volume taken from $22.5 \mathrm{~km}$ below sea level. $B$, Results from a checkerboard resolution test, with the recovered model shown above the input model. 


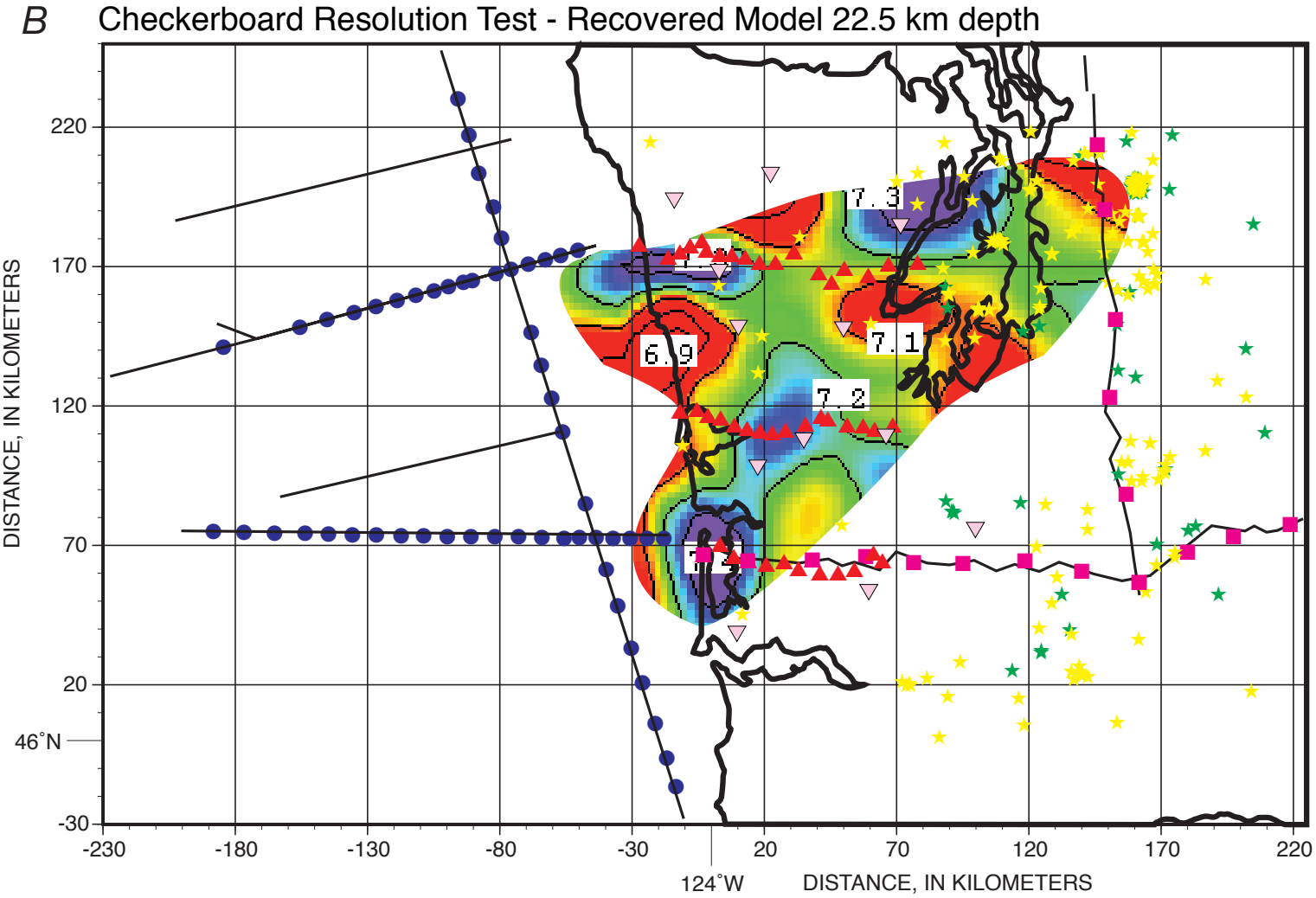

\section{Actual Model}

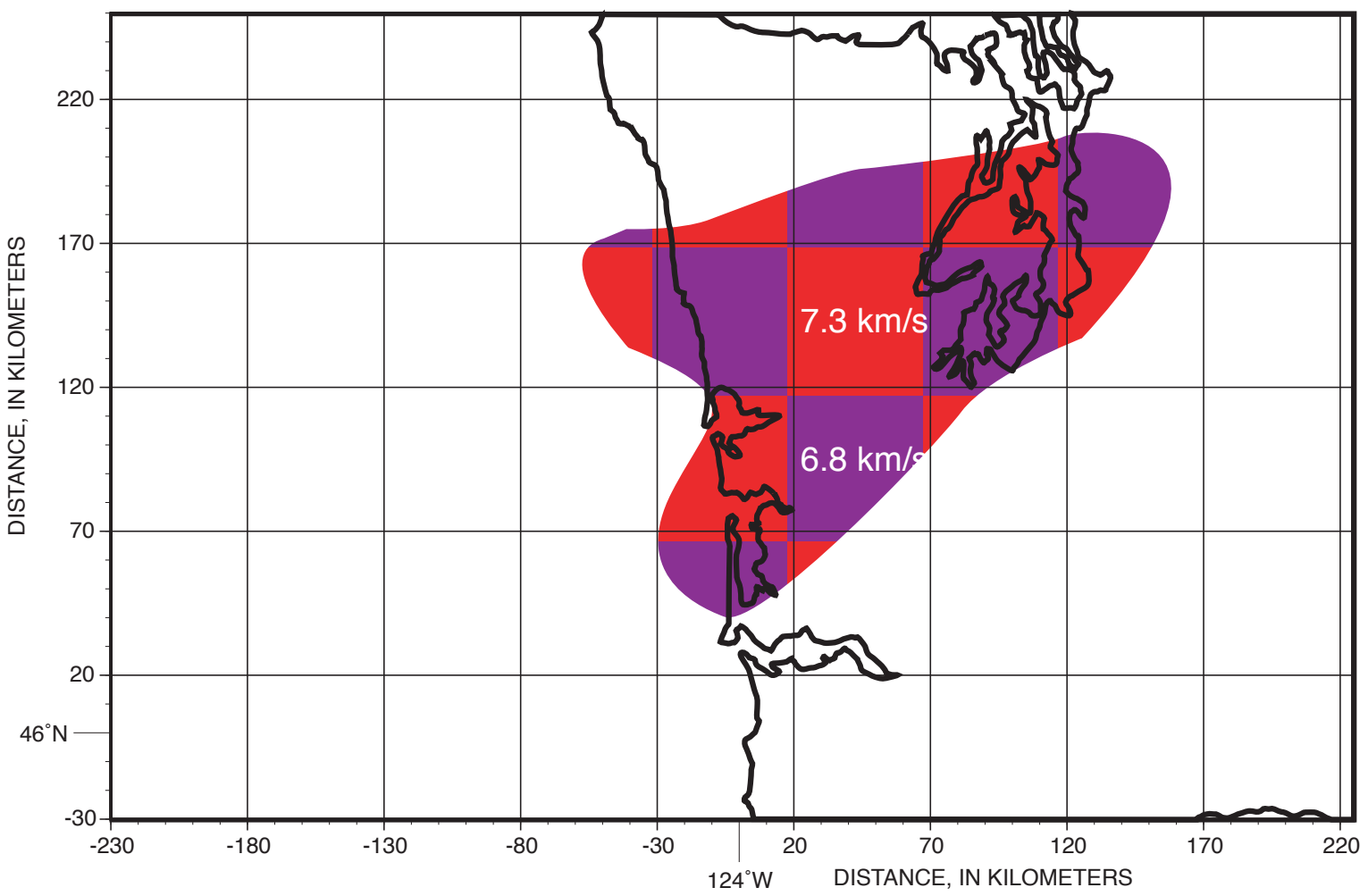

Figure 13.-Continued. 
An important aspect to tomography is scaling the smoothing dimensions appropriately to the input traveltime data. Based on the distribution of seismic sources and receiver stations, resolution of velocity anomalies $\geq 50 \mathrm{~km}$ across in the lateral dimensions and $\geq 10 \mathrm{~km}$ thick in the vertical dimension was sought. Thus a $25-\mathrm{km}$-wide by 5 -km-high smoothing filter was applied during the final iteration, which yielded an RMS traveltime misfit of $0.31 \mathrm{~s}$. A smaller RMS misfit could be achieved, but this would require reducing the model smoothness below the appropriate scale for the input data coverage, resulting in an artificially detailed velocity model.

\section{The Three-dimensional Velocity Structure of Western Washington: Observation}

Horizontal slices from the three-dimensional model volume at $5-\mathrm{km}$ depth intervals that are windowed around the regions of best data coverage, as illustrated by the accompanying hit-count plots, are shown in figures 9-13. An associated checkerboard test for each velocity slice is also shown. All reported depths are depths below sea level.

\section{5-km Depth}

The model had limited coverage at this depth (fig. 9A). Many of the velocity features shown are actually inherited from vertical smoothing of anomalies resolved deeper in the model. The $2.5-\mathrm{km}$ model slice does show fairly uniform velocities of about $4.5 \mathrm{~km} / \mathrm{s}$ in the Coast Ranges, where there is good coverage. The accompanying checkerboard test result (fig. 9B) demonstrates the relatively poor resolution in the uppermost layer. Some of the checkerboard pattern was recovered, though vertical smoothing of deeper, better resolved parts of the test model may have influenced that. Because of the limited coverage at shallow depths away from the controlled-source transects, the low-velocity Seattle and Tacoma Basins beneath Puget Sound (Lees and Crosson, 1990; Symons and Crosson, 1997) were not imaged except very near to the 1991 land refraction profile (figs. $9 A$ and 3 ).

\section{5-km Depth}

The seismic-ray coverage improves with depth into the middle crust and is relatively good in the center of the model at $7.5 \mathrm{~km}$ (fig. 10A). Offshore, fairly low velocity rocks (3.5$5.5 \mathrm{~km} / \mathrm{s}$ ) are imaged. Onshore, a large body of relatively high velocity rocks (>6.0-6.5 km/s) occupies much of the crust, extending from near the coastline to the east of Puget Sound (fig. 10A). The high-velocity rocks are present at the coastline in northern Oregon and southern Washington; farther north along the coast, the high-velocity rocks retreat inland at Grays Harbor and again at the Olympic Mountains. A pattern of alternating east-west-trending bodies of high and low velocity is evident along the coastline.
The resolution test at 7.5-km depth shows reasonably good recovery of the checkerboard pattern (fig. 10B), with edges resolved to within $\pm 10 \mathrm{~km}$ laterally and relative velocities resolved to an average of $\pm 0.15 \mathrm{~km} / \mathrm{s}$. Because of the broad lateral smoothing applied to the velocity model, dips cannot be resolved very accurately. A $\pm 10-\mathrm{km}$ lateral shift at $7.5-\mathrm{km}$ depth implies a $\pm 55^{\circ}$ change in dip between a surface outcrop and the associated velocity anomaly. At this depth, therefore, only very high angle vs. very low angle velocity boundaries can be discriminated.

The observation of an alternating pattern of high and low velocities along the coast looks at first glance to be a result of a coverage bias, in that the three east-west onshore-offshore profiles (where coverage tends to be best) are associated with lower velocities (figure 10A). However, the two southern lines were located in basins, and the northenmost line was located on the accretionary rocks of the Olympic Mountains, where velocities are expected to be lower. South of the Olympic Mountains, the high velocities were modeled from traveltimes to PNSN stations. Immediately south of Grays Harbor, the high velocities may not extend all the way to the coast as shown, given that there is a hole in the coverage there (fig. $10 B$ ). However, the high velocities modeled farther south near the coastline around the mouth of the Columbia River are better constrained (fig. 10B). The generally high velocities modeled north and south of Grays Harbor are not artifacts from the starting model; instead, they result from the addition of the PNSN data. If the PNSN data are excluded from the inversion, the observed velocity pattern is one of lower velocities smeared across the coastal areas. The addition of the PNSN stations reduced the overall RMS misfits; therefore, the higher velocity areas are not a result of any systematic timing errors associated with the earthquake traveltimes.

It is possible that some vertical smearing of very low velocities near the surface could be influencing the velocity image where low-velocity anomalies are observed because of poor coverage in the upper $2 \mathrm{~km}$. However, the low velocities associated with these regions persist through the $12.5-\mathrm{km}$ depth range (see subsequent discussion), exceeding the vertical smoothing dimension ( $5 \mathrm{~km}$ ), and passing through the best covered parts of the model, and they are sampled by rays from sources and receivers away from the areas at the surface that correspond with the lower-velocity regions.

\section{5-km Depth}

At 12.5-km depth, an overall northeast trend of the west edge of higher velocity rocks $(>6.5 \mathrm{~km} / \mathrm{s})$ from Willapa Bay in the south to Puget Sound in the north becomes clear. An embayment of lower velocity rocks $(<6.0 \mathrm{~km} / \mathrm{s})$ at Grays Harbor is still evident at $12.5-\mathrm{km}$ depth (fig. 11A). To the east, high velocities drop off dramatically along a north-trending boundary that corresponds roughly to the west Rainier seismic zone.

Lateral spatial resolution at $12.5-\mathrm{km}$ depth is comparable to that at $7.5-\mathrm{km}$ depth $( \pm 10 \mathrm{~km})($ fig. $11 B)$, though the recovered 
relative velocity resolution is a little worse at about $\pm 0.2 \mathrm{~km} / \mathrm{s}$. The checkerboard pattern recovery continues to be better along the western part of the model window than along its east side.

\section{5-km Depth}

The pattern of higher $(>6.5 \mathrm{~km} / \mathrm{s})$ and lower $(<6.5 \mathrm{~km} / \mathrm{s})$ velocity rocks at $17.5-\mathrm{km}$ depth resembles that at $12.5-\mathrm{km}$ depth (fig. 12A). The western edge of the higher velocity block continues to have a northeast trend. Higher velocity rocks are observed in the offshore region beginning at this depth. Spatial $( \pm 20 \mathrm{~km})$ and velocity resolution $( \pm 0.3 \mathrm{~km} / \mathrm{s})$ are reduced relative to shallower slices (fig. 12B).

\section{5-km Depth}

The relatively consistent observation of a higher velocity body of rocks onshore as compared with the offshore region between $2.5-\mathrm{km}$ and $17.5-\mathrm{km}$ depth is lacking at this depth (fig. 13A). Instead, fairly uniform $6.5-7.0 \mathrm{~km} / \mathrm{s}$ rocks are continuously distributed. Vertical and horizontal resolution tests were conducted on the onshore high-velocity anomaly at $22.5-\mathrm{km}$ depth. The checkerboard pattern was shifted from that in layers above to test the lateral resolution while eliminating the possibility that the recovered pattern might incorporate some smoothing from layers above where there was better seismicray coverage. It was found that the checkerboard pattern could be recovered to some extent, with a lateral resolution of \pm $15-20 \mathrm{~km}$, and $\pm 0.2 \mathrm{~km} / \mathrm{s}$ resolution in velocity. Thus, if there was a lateral velocity contrast such as was observed at all other depths in the model, it should be evident at $22.5 \mathrm{~km}$ depth.

\section{The Three-dimensional Velocity Structure of Western Washington: Interpretation}

The primary goal in generating the three-dimensional velocity model was to identify the boundary between Siletzia and the sedimentary rocks accreted against it. Siletzia in western Washington is made up of the Crescent Formation and comprises massive and pillowed basalt flows cut by diabase dikes (Tabor and Cady, 1978). In contrast, where exposed in the Olympic Mountains, the sedimentary rocks accreted against Siletzia are primarily sandstones and mudstones of increasing metamorphic grade from east to west (Tabor and Cady, 1978; Brandon and Calderwood, 1990). Thus it is expected that Siletzia rocks are much higher velocity than the accreted sedimentary complex. To interpret the actual boundary between these rocks, their velocity-depth functions are needed; although some data exist for the Siletz terrane (N.I. Christensen, written communication, 1999; Parsons and others, 1998), little is known about the accretionary complex. However, some insight can be gained from a global compilation of velocity measurements that shows a fairly narrow transition from metamorphosed sedimentary rocks into metamorphosed mafic igneous rocks
(Christensen and Mooney, 1995). Given the coarse smoothing applied to the three-dimensional model and resulting velocity resolution $(\sim \pm 0.2 \mathrm{~km} / \mathrm{s})$, such an approach provides reasonable guidelines for interpretation.

In figure 14, the results of Christensen and Mooney (1995) are summarized graphically; the metasedimentary rocks at depth fall below a velocity range of $\sim 6.1-6.4 \mathrm{~km} / \mathrm{s}$, while the mafic intrusive rocks tend to fall above that curve, with the exception of unmetamorphosed basalt. Where exposed in Washington, Siletzia rocks are zeolite to prehnite-pumpellyite facies (Tabor and Cady, 1978). Thus the velocity range between 6.0 and $6.5 \mathrm{~km} / \mathrm{s}$ is interpreted as containing the Siletz-accretionary boundary, which takes into account the average \pm 0.2 $\mathrm{km} / \mathrm{s}$ lateral velocity resolution (fig. 14). In Washington no ultramafic rocks are exposed at the surface in outcrops of Siletzia, but on Vancouver Island the sequence is floored by gabbros (Massey, 1986). Therefore the highest velocities $(\sim 7.0 \mathrm{~km} / \mathrm{s})$ at depth are interpreted as a gabbro layer near the base of the Siletz terrane. Below, geologic interpretations are made of the velocity anomalies identified on slices from the three-dimensional model in the previous sections.

\section{5-km Depth}

High-velocity rocks at depth match fairly closely with the surface outcrops of Siletz rocks and with well data (McFarland, 1979) (figs. 3 and 10A). Thus the large body of high-velocity rock that occupies most of the crust onshore is interpreted as the Siletz terrane (fig. 10A) (specifically, the Crescent Formation of the Siletz terrane). The lower velocity anomalies west of the Siletz terrane and offshore are interpreted as accreted sedimentary rocks. At depth, high velocities are seen at varying offsets to the east of the near-surface contact between Siletzia and accreted sedimentary rocks (fig. 10A). The near-surface and 7.5-km-deep contacts are nearly coincident in northern Oregon and southern Washington, while a significant eastward shift north of Willapa Bay is observed (fig. 10A). This appears as a high-angle contact to the south and a lower angle contact to the north; Snavely and Wagner (1982) also concluded that the Siletz-accretionary contact is low angle $\left(25^{\circ}\right)$ north of Willapa Bay. North of Grays Harbor, the higher velocities of the Siletz terrane are evident wrapping around the Olympic Mountains uplift. Correspondence between the surface outcrops of the Siletz terrane and the high-velocity anomalies at depth suggests a high-angle Siletzaccretionary prism contact in the uppermost crust.

The alternating pattern of high and low velocities observed along the coast (fig. 10A) may be the result of regional north-south directed compression (McCrory, 1996) that causes folding, variable thinning, and imbrication of the Siletz terrane. Regional north-south compression may have domed the Siletz terrane south of Grays Harbor and in the Olympic Mountains along roughly east-west axes and created an intervening synform. The relatively low velocities associated with the southern Grays Harbor region correspond with 
the Chehalis Basin and imply that the basin is deep and has only a thin veneer of Crescent Formation near the surface; north of Grays Harbor the low velocities may indicate that the Crescent Formation is downwarped. Relatively low velocities also coincide with the accreted sedimentary core of the anticlinal Olympic Mountains uplift (Tabor and Cady, 1978).

The eastern edge of the Siletz terrane is more poorly constrained by the model; high-velocity rocks appear to be absent beneath the 1991 refraction profile at $7.5-\mathrm{km}$ depth where 5.0 $\mathrm{km} / \mathrm{s}$ velocities are observed. Miller and others (1997) analyzed the complete 1991 line and show velocities consistent with Siletz terrane at greater depth. Moran (1997) conducted a three-dimensional inversion using local earthquake sources centered east of Puget Sound and found a prominent north-south trending velocity boundary $50 \mathrm{~km}$ east of Puget Sound beginning at $\sim 10 \mathrm{~km}$ depth that was interpreted as the east edge of the Siletz terrane.

\section{5-km Depth}

The boundary between accreted sedimentary rocks and the Siletz terrane makes a northeast trending boundary that occurs somewhat farther inland than it did at 7.5-km depth (fig. 11A). Missing at this depth are the alternating high- and low-velocity patterns evident at 7.5-km depth. In the southern Olympic Mountains and at Willapa Bay, significant northeast shifts in the terrane boundary with increasing depth can be seen by comparing its location at the surface and at depth (figs. $11 \mathrm{~A}$ and 15). These shifts may be evidence for a thin west edge of the Siletz terrane or for shallow crustal faults that offset the surface outcrops of Siletz terrane from their deeper roots in the depth range between 7.5 and $12.5 \mathrm{~km}$. In an inversion centered in the Puget Sound region, Lees and Crosson (1990) measured an $18^{\circ}$ to $28^{\circ}$ dip on this contact near the eastern Olympic Mountains, comparable to that imaged by Clowes and others (1987) and Calvert (1996) at southern Vancouver Island. An interpretation of magnetotelluric data shows that the accreted sedimentary rocks do not underthrust the Siletz block at depths greater than $\sim 10 \mathrm{~km}$ beneath Puget Sound (Aprea and others, 1998).

The low-velocity anomaly at Grays Harbor persists to 12.5-km depth (fig. 11A); the uniform velocities from the accretionary prism to the onshore parts of this area may imply that accretionary rocks were pushed onshore in similar fashion

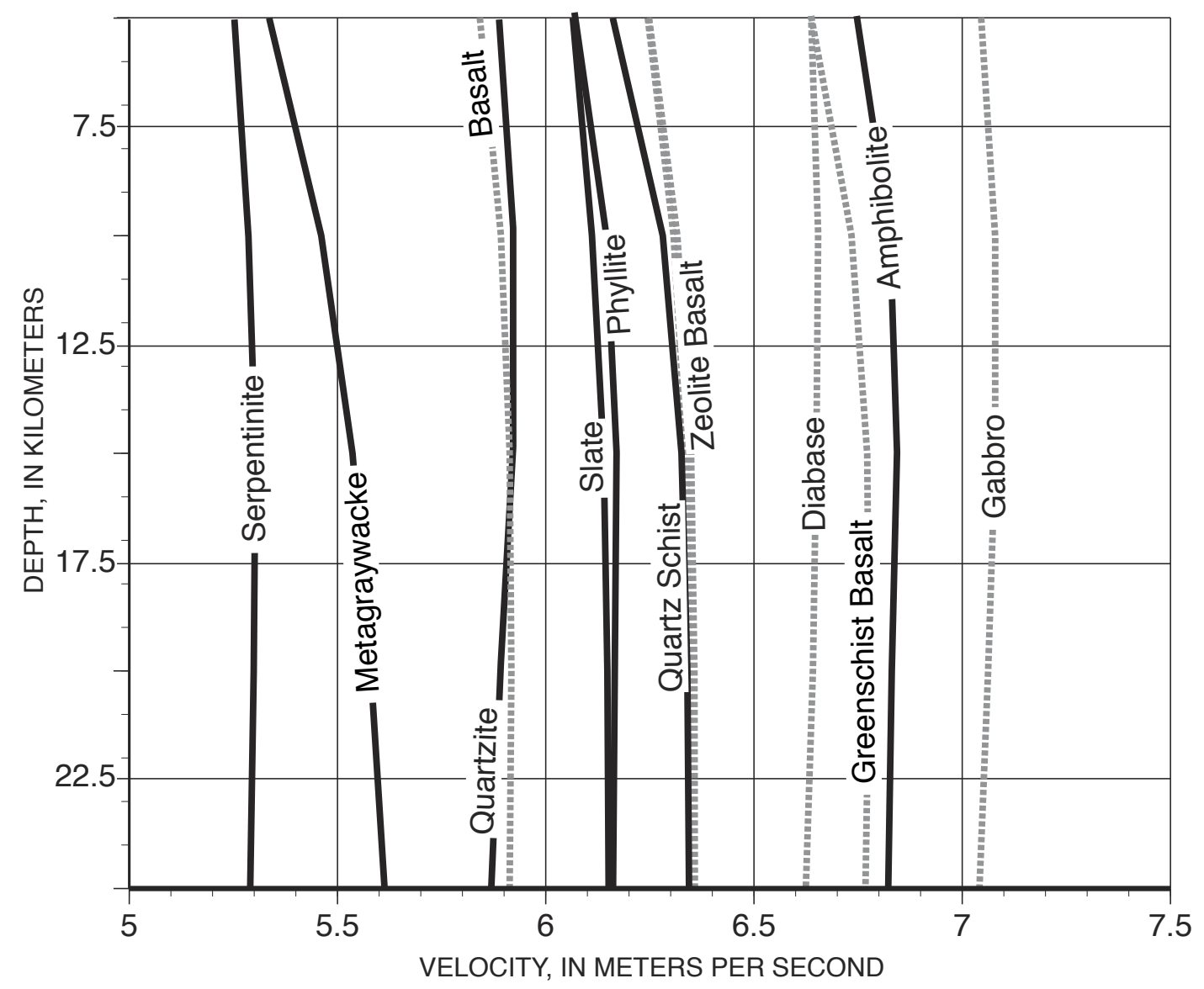

Figure 14. Velocity-depth curves from global averages of hundreds of measured samples of the major classes of metamorphic, and igneous rocks (Christensen and Mooney, 1995) of likely composition and grade to be found in the upper $25 \mathrm{~km}$ of the Cascadia subduction zone (Best, 1982). Given the $2 \mathrm{~km} / \mathrm{s}$ lateral velocity resolution of the three-dimensional velocity model, the Siletz-accretionary complex boundary is contained in the velocity interval between 6.0 and $6.5 \mathrm{~km} / \mathrm{s}$. 
as to the north beneath the Olympic Mountains. To the east, high velocities drop off dramatically along a north-trending boundary that corresponds roughly to the west Rainier seismic zone, consistent with previous interpretations that the deformation is occurring along the Siletzia boundary based on gravity data (Finn, 1990; Stanley and others, 1996).

\section{5-km Depth}

The primary change between $12.5-\mathrm{km}$ and $17.5-\mathrm{km}$ depth is the observation of high-velocity rocks in the offshore region. These higher velocities are interpreted as oceanic crust of the downgoing Juan de Fuca slab. Velocities appropriate for accretionary rocks make a nearly continuous linear boundary along the western edge of the Siletz terrane. A possible explanation for this may be that the compressional deformation (folding or faulting) of Siletzia is more pronounced at shallower depths. The north-trending eastern boundary also persists at $17.5-\mathrm{km}$ depth, consistent with a high-angle boundary.

\section{5-km Depth}

At this depth the northeast-trending lateral velocity contrast as observed from $2.5-\mathrm{km}$ to $17.5-\mathrm{km}$ depth is not resolved. This change may indicate that the base of the Siletz terrane occurs near this depth (to within $\pm 5 \mathrm{~km}$ ). The modeled $18-28-\mathrm{km}$ thickness is in reasonable agreement with the estimates made from two-dimensional profiles (Tréhu and others, 1994; Parsons and others, 1998). This depth coincides with a horizontal band of seismicity beneath Puget Sound (Stanley and others, 1996) and might imply that there is some deformation along the base of the Siletz terrane.

\section{Discussion of the Three-Dimensional Seismic-Velocity Model of Coastal Washington}

The large-scale boundaries between the Siletz terrane and the adjacent accretionary prism and volcanic arc in western Washington were imaged in three dimensions. Internal deformation in Siletzia that manifests as alternating thinning and thickening along the Washington coast (fig. 10A) may result from folding and imbrication of the Siletz block on low-angle faults in the shallow crust (fig. 15). The thick Siletz terrane of Oregon (Tréhu and others, 1994) persists near the coast as far north as southern Willapa Bay. North of Willapa Bay, at the latitude of Grays Harbor, the west edge of the Siletz terrane is thinned and has a lower angle contact with the accretionary prism (fig. 15). This is consistent with deformation of the Crescent Formation basalt along the coast, where it is exposed in seaward-vergent overturned anticlines in the hanging walls of landward-dipping thrust faults (Snavely and Wagner, 1982; Wells and Coe, 1985). Seismic models from east of the Olym- pic Mountains and on Vancouver Island also show shallow easterly dips of the Siletz terrane in the upper $10 \mathrm{~km}$, with accretionary rocks beneath it (Symons and Crosson, 1997; Lees and Crosson, 1990; Clowes and others, 1987; Calvert, 1996), and Pratt and others (1997) suggest a low-angle detachment beneath Puget Sound between 14-km and 20-km depth. Therefore, either the western edge of Siletzia was originally thinner at Willapa Bay and in the Olympic Mountains and is thus more susceptible to deformation, or the more intense deformation in the northern Coast Ranges has involved Siletzia in low-angle faulting.

There is a high-amplitude antiformal uplift centered in the Olympic Mountains, and it appears that similar (but lower amplitude) deformation extends along much of the Washington margin, with uplift between Willapa Bay and Grays Harbor and synforms along the Columbia River and between Grays Harbor and the Olympic Mountains. Outside of the study area, north of the Olympic Mountains, this pattern persists with a synformal structure that coincides with the Strait of Juan de Fuca (Snavely, 1987) (fig. 16). The Bouguer gravity anomaly associated with the Siletz terrane also reflects this pattern, with a coherent gravity high along the Oregon coast that grades into a more complex alternating pattern of highs and lows in Washington (Finn and others, 1991).

The shape of the western edge of the Siletz terrane in Washington may have implications for the geologic evolution of the margin. In Oregon, there is clear paleomagnetic evidence of clockwise rotation of the Siletz terrane (Simpson and Cox, 1977). However, on the Olympic Peninsula to the north, the Crescent Formation shows no rotation or translation (Warnock and others, 1993). Thus Siletzia must have accommodated this variable motion by internal deformation. Northwest-directed translation of central Oregon and southern Washington (Pezzopane and Weldon, 1993) must also have been accommodated. The internal strain of the Siletz terrane may be focused along the coast of the Olympic Peninsula. The large-scale arching of the mafic basement along east-west trends transverse to the margin can be explained by margin-parallel northward transport and rotation of Siletzia into the relatively fixed restraining bend of the Canadian Coast Mountains at Vancouver Island (Wells and others, 1998). The Olympic Peninsula acted as a soft hinge-point, undergoing significant north-south directed deformation. Alternatively, the size of the accretionary complex reflects proximity to the major proto-Columbia River sediment source (Brandon and Vance, 1992) The deformation of Siletzia in Washington then represents the impact of major sediment accretion and possible tectonic erosion of the Crescent Formation along the thrust that locally forms its base in the Olympic Mountains (Tabor and Cady, 1978)

The Siletz terrane acts as a backstop against which accreted rocks are thrust, and this contact may have seismogenic potential. A three-dimensional map of the contact zone at depth is provided that shows a fairly steep angle in northern Oregon and southernmost Washington. To the north, it appears that the Siletz backstop deforms along with the rocks accreted 

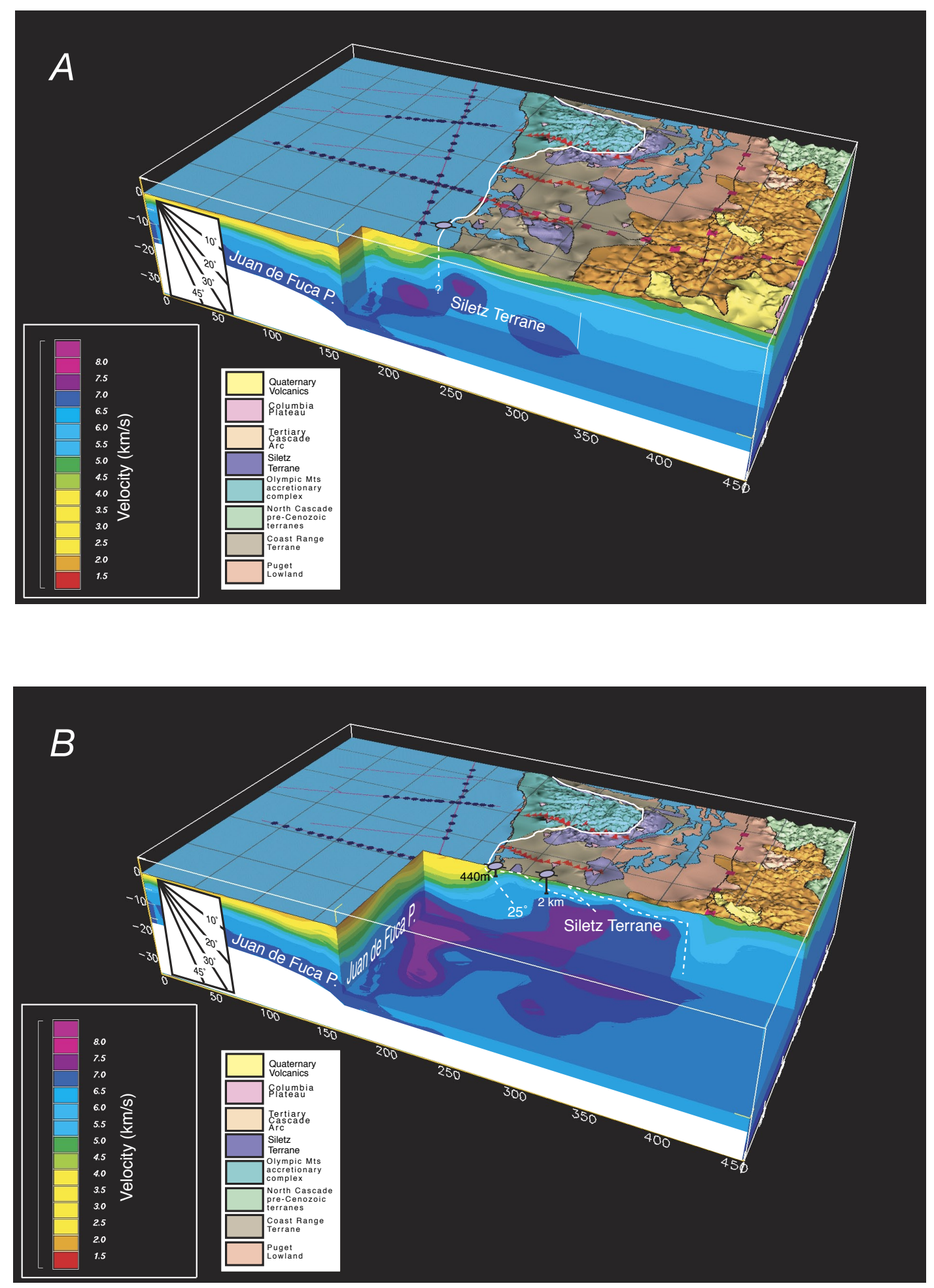

Figure 15. Spaced vertical profiles through the three-dimensional velocity model for coastal Washington, shown with the topography and generalized geology from figure 3 draped above. Vertical and horizontal scales are distance, in kilometers. $A$, Cross section showing the western Siletz-accretionary terrane boundary at the coast of northern Oregon; basalt is present in the well indicated offshore, and thus a high-angle terrane contact is interpreted. The eastern edge of Siletzia is poorly constrained in this cross section. $B$, Basalt is observed in the well marked at the coast in this cross section; however, the main high-velocity anomaly is shifted to the east as compared with the northern Oregon section (A). A $25^{\circ}$ dipping boundary is shown, following Snavely and Wagner (1982), who derived it from well data, shallow seismic-reflection data, and 

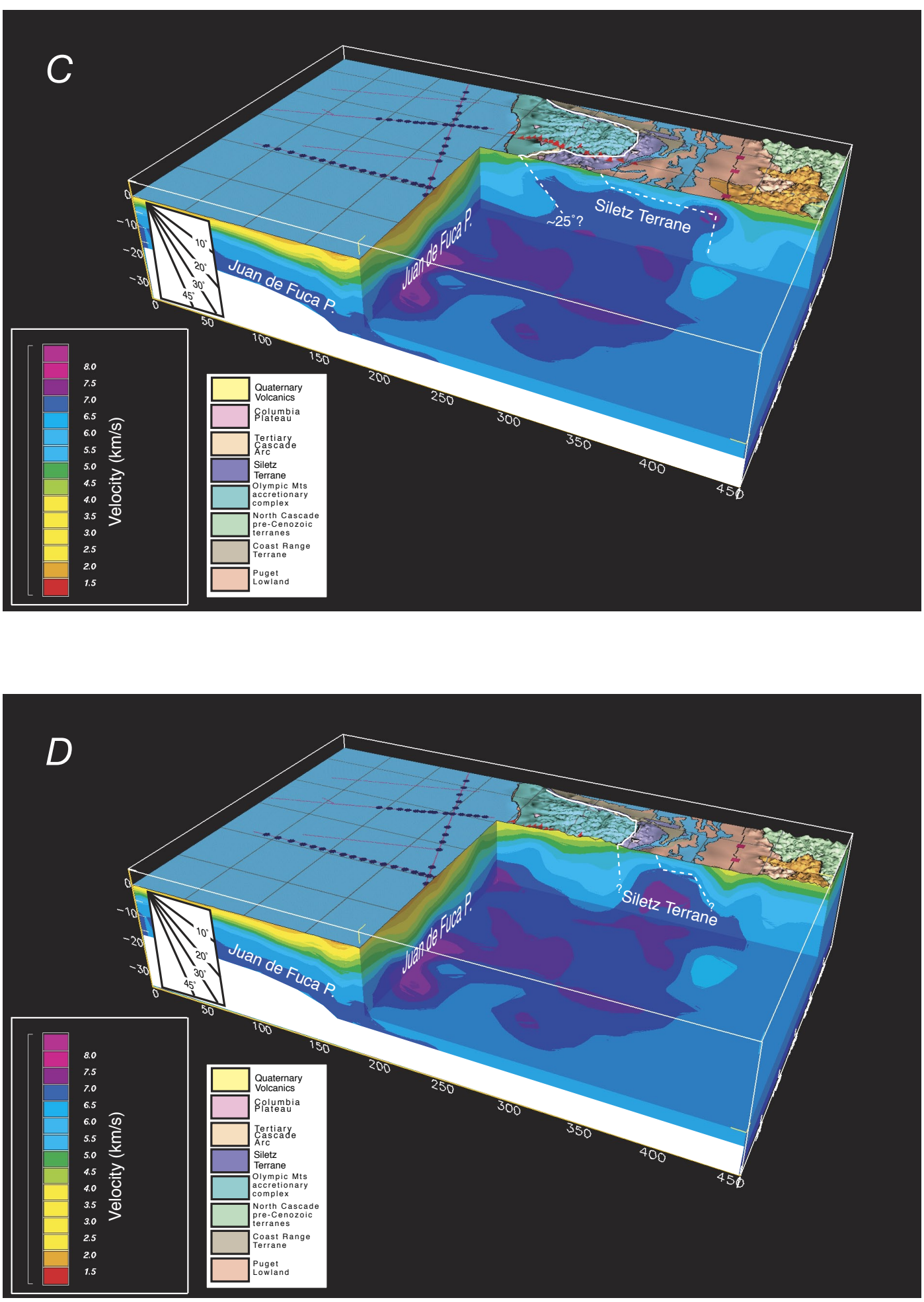

magnetic modeling. Farther inland, a well finds basalt at 2-km depth west of the Doty Fault, which thrusts Siletzia rocks back to the surface (Snavely and Wagner, 1982; Wells and Coe, 1985). A highangle eastern boundary between Siletzia and the Cascade arc is interpreted, coincident with the west Rainier seismic zone (Stanley and others, 1996; Moran, 1997). C, The Siletz terrane can be seen beneath the southern rim of the Olympic Mountains; a $25^{\circ}$ dipping boundary between Siletzia and the underthrust accretionary complex is approximated. $D$, Nearer to the axis of the Olympic Mountains uplift, the Siletz terrane is bent sharply upwards west of Puget Sound, where most of its thickness is exposed at the surface (Tabor and Cady, 1987). 
to it and may have active internal low-angle faults. North of Willapa Bay and in the western Olympic Mountains, the seaward edge of Siletzia appears to be a gently landward-dipping thrust flake overlying imbricated and underthrust sediments of the Cascadia accretionary prism.

\section{Three-Dimensional Crustal Structure of the Puget Lowland from Seismic Traveltimes and Bouguer Gravity}

The Puget Lowland of Washington is seismically active and is crossed by many faults that offset Quaternary deposits, or that have a history of late Holocene rupture (Gower and others, 1985; Atwater and Moore, 1992; Bucknam and others, 1992; Johnson and others, 1994, 1996, 1999). Major crustal fault zones bound the Tacoma, Seattle, and Everett Basins (fig. 6), large geological features that may prolong and amplify the strong ground motions. The Tacoma and Seattle Basins introduce a significant difference in the delay times of first arrivals produced along shot lines in Puget Sound versus Hood Canal. In Puget Sound, traveltime delays produced by the Seattle Basin exceed 1 s (Brocher and others, 2001).

\section{Method}

In this study, observed gravity is incorporated as a sequential step in the inversion process. Thus the method is not a joint inversion in a rigorous sense, where residuals from traveltime and gravity are minimized simultaneously through a linear expression that relates the two. Instead, the gravitational field predicted by a velocity model obtained from traveltime inversion is compared with observed gravity. Velocities are modified to reduce residuals, and then used as the starting model for the next traveltime iteration. A fixed velocity-density relation enables all output models to be expressed as both velocity and density; the technique could be readily modified to incorporate spatially variable velocity-density relations if desired.

As before, the three-dimensional tomographic technique of Hole (1992) was used for seismic traveltime inversion. The updated velocity model from traveltime inversions was passed to the gravity step as a starting model. The gravity algorithm was applied sequentially in three dimensions, but it can easily be adapted for use with any gridded or node-based traveltime modeling method in two dimensions or three.

For the example presented here, the gravity anomaly was calculated on the first iteration of the velocity model by converting velocity to density using Gardner's nonlinear rule of $\rho=1740 v^{1 / 4}$ for velocities (in $\mathrm{km} / \mathrm{s}$ ) below $6 \mathrm{~km} / \mathrm{s}$ (Gardner and others, 1974) and $\rho=2920 \mathrm{~kg} / \mathrm{m}^{3}$ for velocities greater than $6 \mathrm{~km} / \mathrm{s}$, which correspond to the Crescent formation (Brocher and others, 2001) (fig. 17). These choices may be modified for other regions as necessary. The gravity anomaly $g(x, y)$ of a three-dimensional density distribution $r(x, y, z)$ is the sum of the effecdividual layer of the model. Let $r(x, y, z)$ be discretized by layers, so that $r(x, y, z)=r_{k}(x, y)$, direct the $z$ axis downward, and denote the two-dimensional Fourier transform by

$$
\mathcal{F}[f]=\int_{-\infty}^{\infty} \int_{-\infty}^{\infty} f\left(x^{\prime}, y^{\prime}\right) \exp \left(-i\left(k_{x} x^{\prime}+k_{y} y^{\prime}\right)\right) d x^{\prime} d y^{\prime}
$$

where $k_{x}$ and $k_{y}$ are wavenumbers for the $x$ and $y$ directions, respectively. The gravity anomaly due to the entire density distribution is given by

$$
g(x, y)=\sum_{k=1}^{N} f_{k}(x, y)
$$

where

$$
\mathcal{F}\left[f_{k}\right]=\mathcal{F}\left[\rho_{k}\right] \cdot \mathcal{F}[e]
$$

The function $\mathcal{F}[e]$ is the gravitational earth filter (Blakely, 1995) given by

$$
\mathcal{F}[e]=\frac{2 \pi \gamma}{k}\left(\exp \left(-k z_{1}\right)-\exp \left(-k z_{2}\right)\right), z_{1}>0, z_{2}>z_{1}
$$

where $g$ is the gravitational constant, $z_{1}$ and $z_{2}$ are depths to the top and bottom of layer $k$, respectively, and $k=\sqrt{k_{x}^{2}+k_{y}^{2}}$. Thus, the gravity anomaly due to each layer was calculated by (1) Fourier transforming the two-dimensional density of each layer, (2) multiplying by the appropriate earth filter, and (3) inverse Fourier transforming the product. Layers with uniform density (inferred from uniform velocity) were ignored, as they would add only a constant to the overall anomaly.

The calculated anomaly is subtracted from observed gravity, which is gridded at the same scale as the top surface of the three-dimensional velocity model (squares $1 \mathrm{~km}$ by $1 \mathrm{~km}$ in this study), yielding a set of residual gravity values. The velocity model, represented by $1-\mathrm{km}$ cubed cells of constant velocity and density, is then changed to minimize the residuals. A challenge is posed in fitting gravity observations because the observed anomaly at the surface is relatively independent of the depth of the source, yielding many possible models that satisfy the observations. Some assumptions were made (as described below), and constraints from seismic traveltime modeling were applied to make targeted changes in the velocity-depth relation in each column in the velocity model. These changes resulted in a model that is consistent with observed gravity and seismic traveltimes.

Initially a grid of residual scaling factors was generated, each a function of the magnitude and sign of the corresponding residual gravity value, namely

$$
R(x, y)=\frac{(r(x, y)-\bar{r})}{\delta}
$$




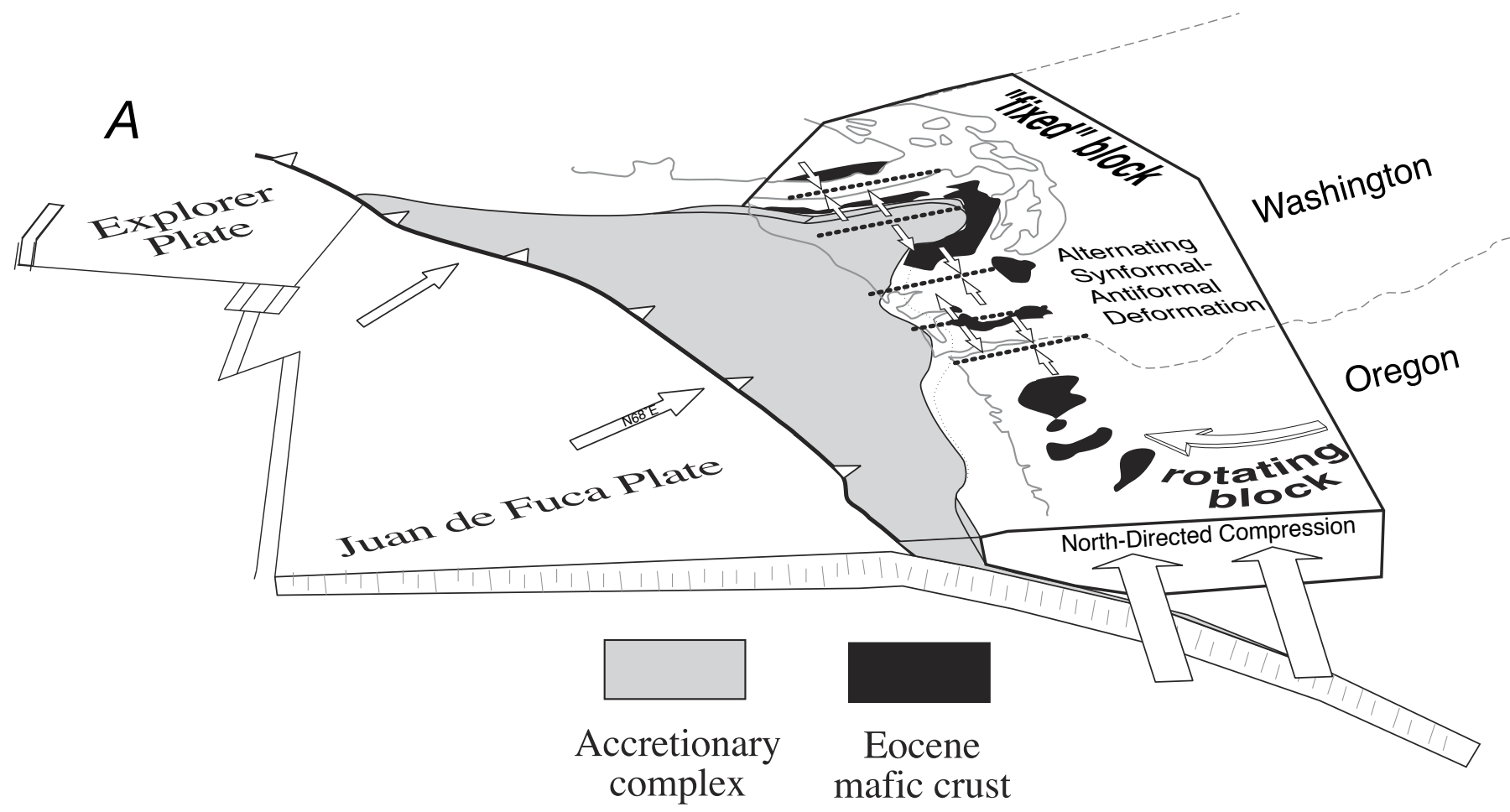

$B$

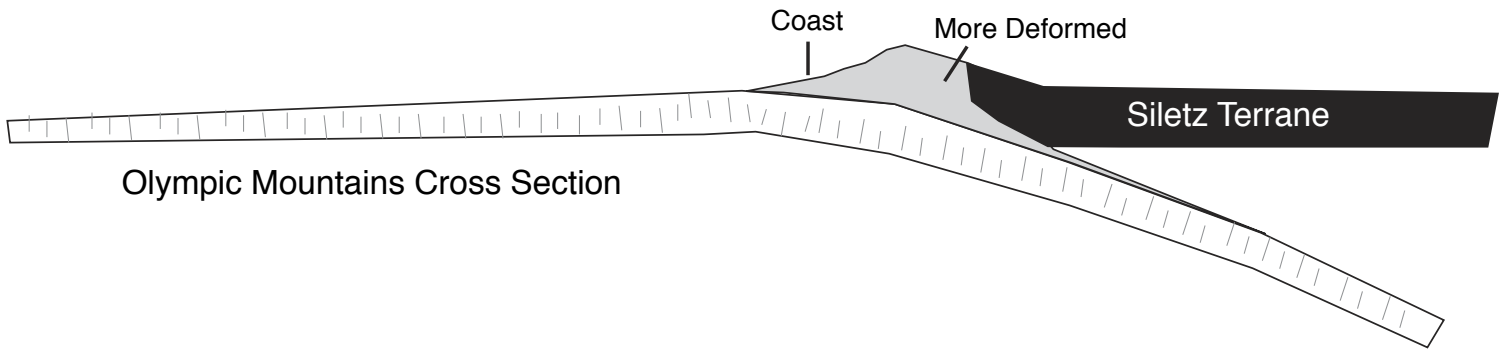

Coast Less Deformed

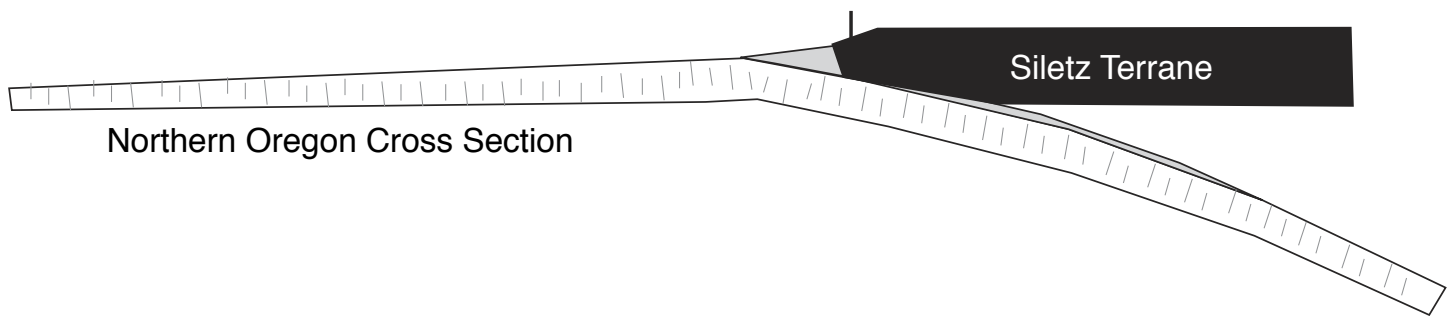

Figure 16. Tectonic model of Siletz-terrane deformation. $A$, North-directed compressional stress and southern Siletz terrane rotation are accommodated at a hinge point along the coast of the Olympic Peninsula. The greatest amplitude of uplift occurs at the Olympic Mountains, but the pattern of folding persists north and south of the Olympics. This may occur as a result of the margin-parallel northward transport and rotation of Siletzia into the relatively fixed restraining bend of the Canadian Coast Mountains at Vancouver Island. $B$, Comparative cross sections through northern Oregon and the Olympic Mountains indicate the relationship between backstop deformation and sedimentary accretion, although whether this relationship is causative remains an open question. 
where $r(x, y)$ is the residual at a grid point, $\bar{r}$ is the mean of all gravity residuals, and $\delta$ is an input constant used to scale the magnitude of velocity change. Larger values of $\delta$ cause smaller incremental changes in the velocity model with each iteration, allowing the effects of traveltime and gravity steps to gradually evolve a model consistent with both data sets. Appropriate $\delta$ values were determined by experimenting with different numbers, using lowered RMS misfit in traveltime and gravity as the criterion.

The second step of the algorithm is calculation of the velocity-depth gradient $(d V / d z)$ at each model cell. The gradients are found by finite differencing the gridded velocity model. Gradient values are used to scale the velocity perturbations by maximizing changes where the gradients are highest, based on the assumption that much of the variation in the gravity anomaly results from sedimentary basin structures near the surface. Slight increases or decreases in the model depth to basement can quickly satisfy the residuals. In many cases, crustal tomography studies are undertaken to resolve basin structures (models for assessing likely earthquake strong ground motion for example). Preferentially changing velocity where gradients are highest has an effect akin to subtly moving the depth to the basement-sediment interface. Subsequent traveltime iterations allow such changes only within the allowable range that still satisfy the traveltime data.

The last scale applied on velocity perturbation resulting from gravity residuals is a seismic coverage factor. Perturbations were scaled relative to the degree of calculated seismic ray coverage in a given model cell by

$$
C(x, y, z)=1-\omega\left(\frac{h(x, y, z)}{\alpha}\right)
$$

where $h(x, y, z)$ is a hit count (number of times a seismic ray is calculated to encounter a model cell), $\alpha$ is the maximum hit count in the model, and $\omega$ is a weighting factor (can range from 0 to 1 ; a value of 0.1 was used in this study). Use of this scaling factor enables the model to be preserved where seismic coverage is high and allows more variation where seismic coverage is low or nonexistent. Thus the gavity field can be used to supplement traveltime coverage. The weighting value $\mathrm{w}$ is an input parameter and allows control on how much weight to give the traveltime data versus the gravity data. In the test cases, most weight was given to seismic traveltimes because they are more sensitive to depth than residual gravity values, which are affected primarily by variations in basin structure. Model velocity is changed by a simple product of the three scaling factors as

$$
V^{i}(x, y, z)=V^{\circ}(x, y, z)+\left(R(x, y) \cdot\left|\frac{d V^{\circ}(x, y, z)}{d z}\right| \cdot C(x, y, z)\right) \cdot(7)
$$

If any of the scaling factors approach zero at a given cell, then velocity is unchanged. Thus when the residuals grow very small, or when the velocity gradient is zero, the velocity perturbation approaches zero. The coverage scale $C(x, y, z)$ is equal to 1 when the seismic hit count in a cell is zero (see equation 6), meaning that the perturbed velocity model is a function solely of the starting model and the gravity residuals in that case. Maximum and minimum allowable velocity-depth ranges are set that prevent unrealistic model velocities from developing. In this study, these ranges were set to the minima and maxima obtained from laboratory analysis at confining pressure of regional rock samples (Brocher and others, 2001). Lastly, a spatial smoothing filter is applied that minimizes vertical streaking, since perturbations are made column by column.

An example of the iterative process is shown in figure 18. The largest changes in the velocity-depth curve occur at depths with steepest gradients and relatively little seismic coverage. The velocity-depth curve is slightly smoothed as a result of introducing the gravity constraint, especially where seismic coverage is minimal (fig. 18). This example is a representative column of the test model and traveltime database (more fully discussed in a later section) and demonstrates the fairly minimal velocity perturbations necessary to satisfy both the traveltimes and the gravity anomalies.

\section{Resolution and Test Models}

Following the methods used in the three-dimensional velocity modeling of coastal Washington, checkerboard tests were conducted by calculating synthetic traveltime picks between all the SHIPS source and receiver positions. In addition, a synthetic gravity field was calculated with a model of vertical columns $10 \mathrm{~km}$ by $10 \mathrm{~km}$, each with alternating increasing velocity gradients that were $0.5 \mathrm{~km} / \mathrm{s}$ different at all depths. The synthetic traveltime picks and synthetic gravity grid were then used with a 1-D starting velocity model to recover the checkerboard pattern by sequential inversion, and the result was compared with the result of using only the traveltime picks.

Results from resolution tests limited to seismic traveltimes show recovery of a smoothed version of the checkerboard pattern only in regions where seismic-ray coverage is high (figs. 19, 20) (see also Brocher and others, 2001). Significant improvement is made by sequentially incorporating the gravity constraints, particularly in areas with minimal seismic coverage. The improvement is primarily recovery of the shape and scale of relative velocity variation rather than recovery of absolute velocities because a fixed velocity-density relation was used. The estimated confidence in locating the actual boundaries improves with the addition of gravity; Brocher and others (2001) estimated that anomalies greater than $15 \mathrm{~km}$ across were resolvable using only traveltimes. Here $10-\mathrm{km}$ anomalies are well resolved.

The checkerboard resolution tests indicate some utility of the gravity inversion in extending the model outside of the seismic coverage because the checkerboard pattern is recovered in those regions (fig. 19). Spatial smoothing of the model extends the influence of seismically determined velocities by the half-width of the smoother. Beyond this distance 


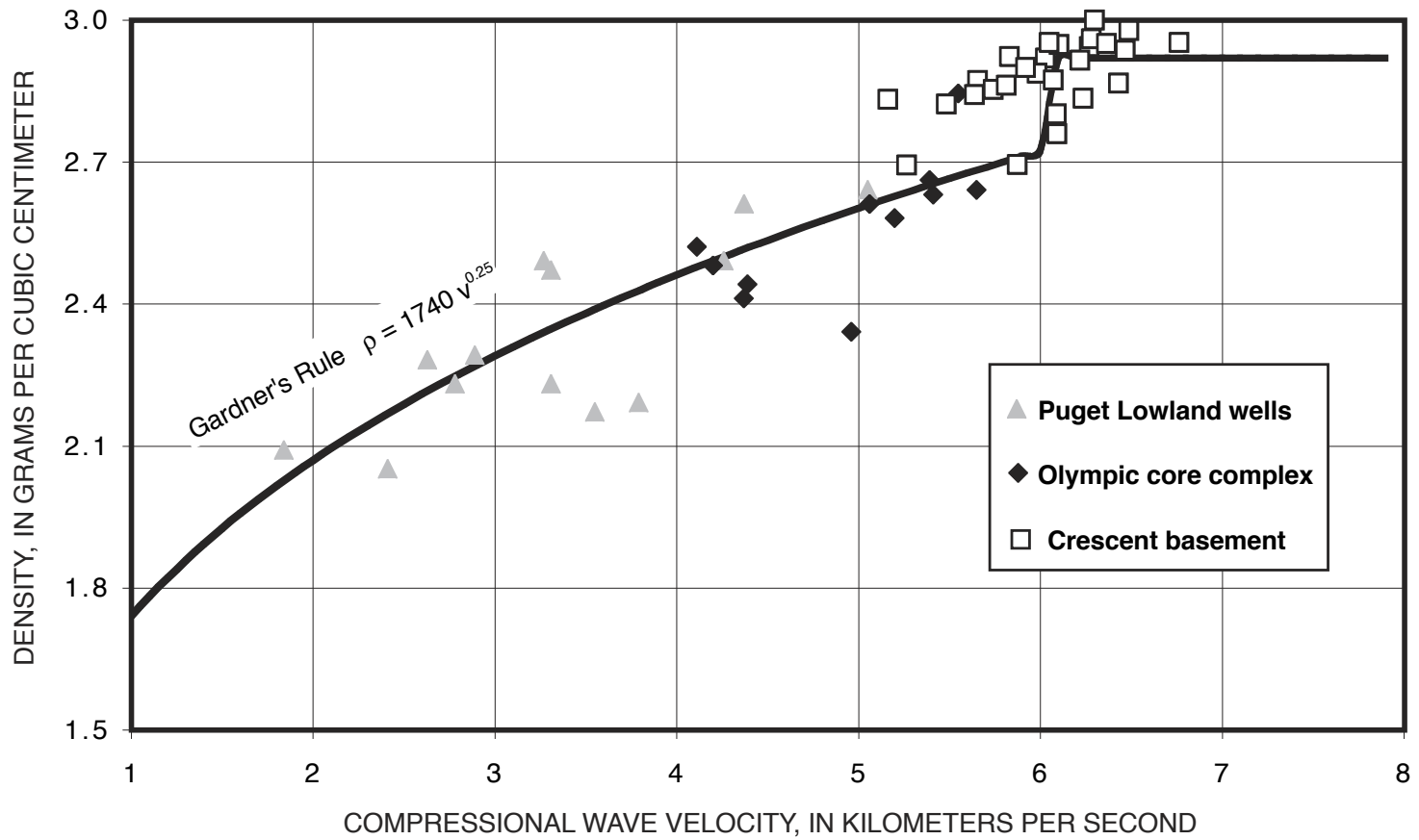

Figure 17. Plot of observed velocity vs. density from Puget Lowland rock samples, compared with the Gardner's rule (Gardner and others, 1974) relation (heavy black line) used in sequential seismic traveltime and gravity inversion for crustal structure.

the gravity inversion is highly sensitive to the starting-model velocity gradient and will tend to suggest sedimentary basins where the observed anomaly is low and basement highs corresponding with gravity highs. Without some guidance from the starting velocity model, features such as low-density granitic plutons or high-density carbonates or mafic intrusions would probably be mishandled. Low-velocity zones are also unlikely to be properly resolved in areas lacking seismic coverage unless the starting model includes reverse gradients with depth.

\section{Application and Evaluation}

Resolution tests using synthetic data sets based on a real geometry show improvements to a velocity model by incorporating sequential gravity iterations. In this section the crustal structure of the Puget Lowlands was calculated using traveltime data from the SHIPS experiment and the observed gravity anomaly for the Puget Lowland study area of Brocher and others (2001) (figs. 6, 21). The gravity observations were discretized onto a surface grid of cells $1 \mathrm{~km}$ by $1 \mathrm{~km}$ that corresponds to the $1-\mathrm{km}$ cubes in the three-dimensional velocity model (fig. 21). The best results in terms of reducing traveltime and gravity residuals were achieved by running five iterations using traveltime only, and then introducing the gravity constraints sequentially with traveltime iterations for another five iterations. Because of the distribution of seismic sources and receiver stations, resolution of velocity anomalies $\sim 5-10 \mathrm{~km}$ across in the lateral dimensions was sought. A 5-km halfwidth smoothing filter was applied during the final iteration, which yielded an RMS traveltime misfit of $0.09 \mathrm{~s}$, and a $5 \mathrm{mGal}$ RMS misfit to the gravity. Introduction of the gravity constraint necessitated some minor station corrections

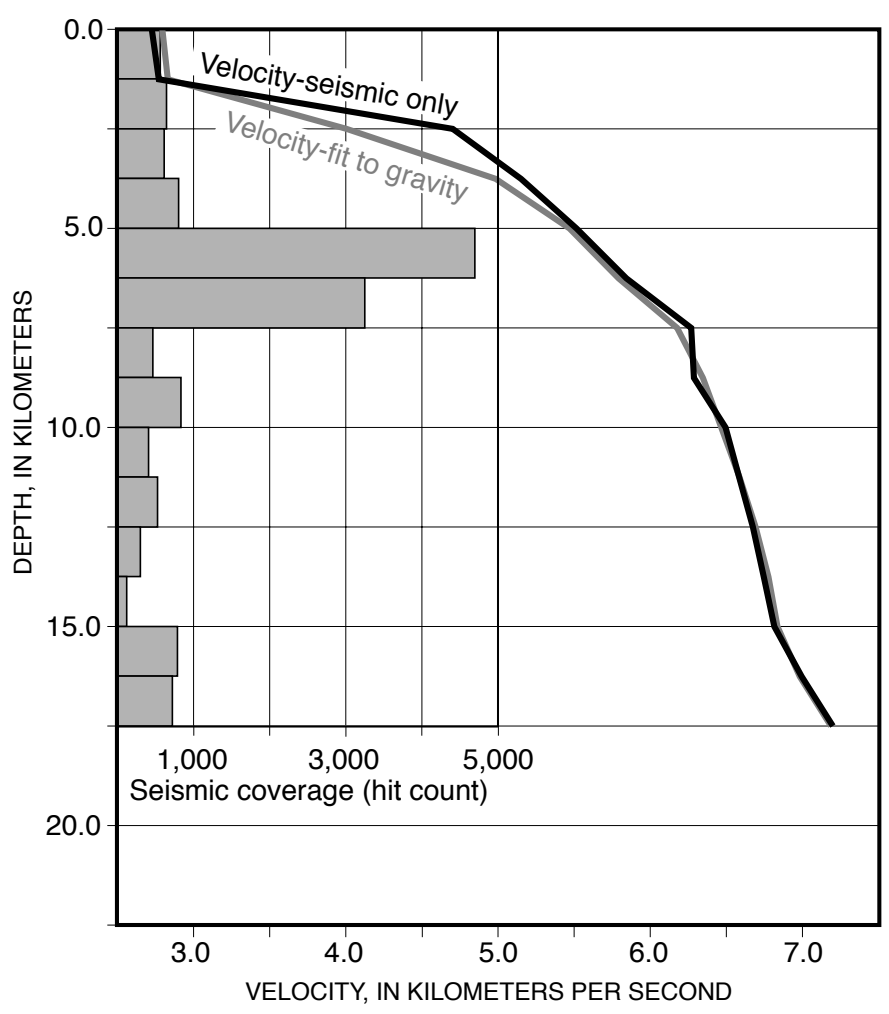

Figure 18. Comparison of velocity-depth profiles taken from threedimensional models derived from seismic traveltimes only (black line) with those derived from combined analysis of traveltimes and gravity (gray line). Adjacent bar graph shows depth variation of seismic hit counts (see text for explanation) associated with the velocity-depth curves. Perturbation introduced by incorporating gravity is greatest where the velocity gradient is steepest (depths between 1 and $4 \mathrm{~km}$ ) and where seismic coverage is sparse. 
to achieve the 0.09-s RMS traveltime misfit. At some stations, traveltime misfits were consistently shifted either positively or negatively, without dependence on source azimuth and range; in these cases the mean traveltime residual was subtracted from the RMS residual. Introduction of the gravity constraint caused this problem because seismic coverage is very sparse in the upper 1-2 km of the model, and lateral smoothing of nearby localized velocity anomalies affected velocity immediately beneath some stations.

\section{Recovery of the Gravity Anomaly}

In figure 21, a comparison is made of predicted gravity calculated from velocity models developed with and without sequential gravity steps. As expected, the velocity model calculated with gravity and seismic traveltimes reproduces more features of the observed gravity anomaly than does the traveltime-only model. However, in the Tacoma Basin the calculated anomaly does not match well with the observed; the anomaly associated with the Tacoma Basin is reproduced only slightly better by the combined model. It appears that density is lower for a given velocity in the Tacoma Basin as compared with the Seattle Basin, where the calculated anomaly agrees well with the observed (fig. 21). This circumstance indicates that, in some cases, a spatially varying velocity-density relationship might be desired to best resolve structure.

\section{Comparison of Velocity Models with Known Geologic Features}

The velocity model that resulted from sequential inversion of traveltimes and gravity is shown at $5-\mathrm{km}$ depth in figure 22 , where a comparison is made between a model generated from the traveltime data only and one that was fit to traveltimes and the gravity anomaly. Evaluation of results from applying the sequential gravity steps to the SHIPS model is subjective, because the actual subsurface structure is unknown. There are, however, some features in the combined model that appear better correlated with surface geology and inferred, related deeper structure. For example, the accreted sedimentary core of the anticlinal Olympic Mountains uplift is expected to have lower seismic velocity than their backstop, the Eocene volcanic rocks of the Crescent Formation that form a rim around the Olympic Mountains (Tabor and Cady, 1978; Parsons and others, 1999). The rim of high-velocity Crescent rocks is well resolved by the traveltime model, but there is only a limited image of lower velocity Olympic-core rocks inside the rim because of poor seismic coverage (figs. 20,22). With the incorporation of gravity, lower velocity core rocks are more evident, and the rim of Crescent Formation rocks is resolved farther west than before.

Another example is the southern Whidbey Island Fault, discussed by Johnson and others (1996), which is resolved by the traveltime model as bounding the Seattle Basin on

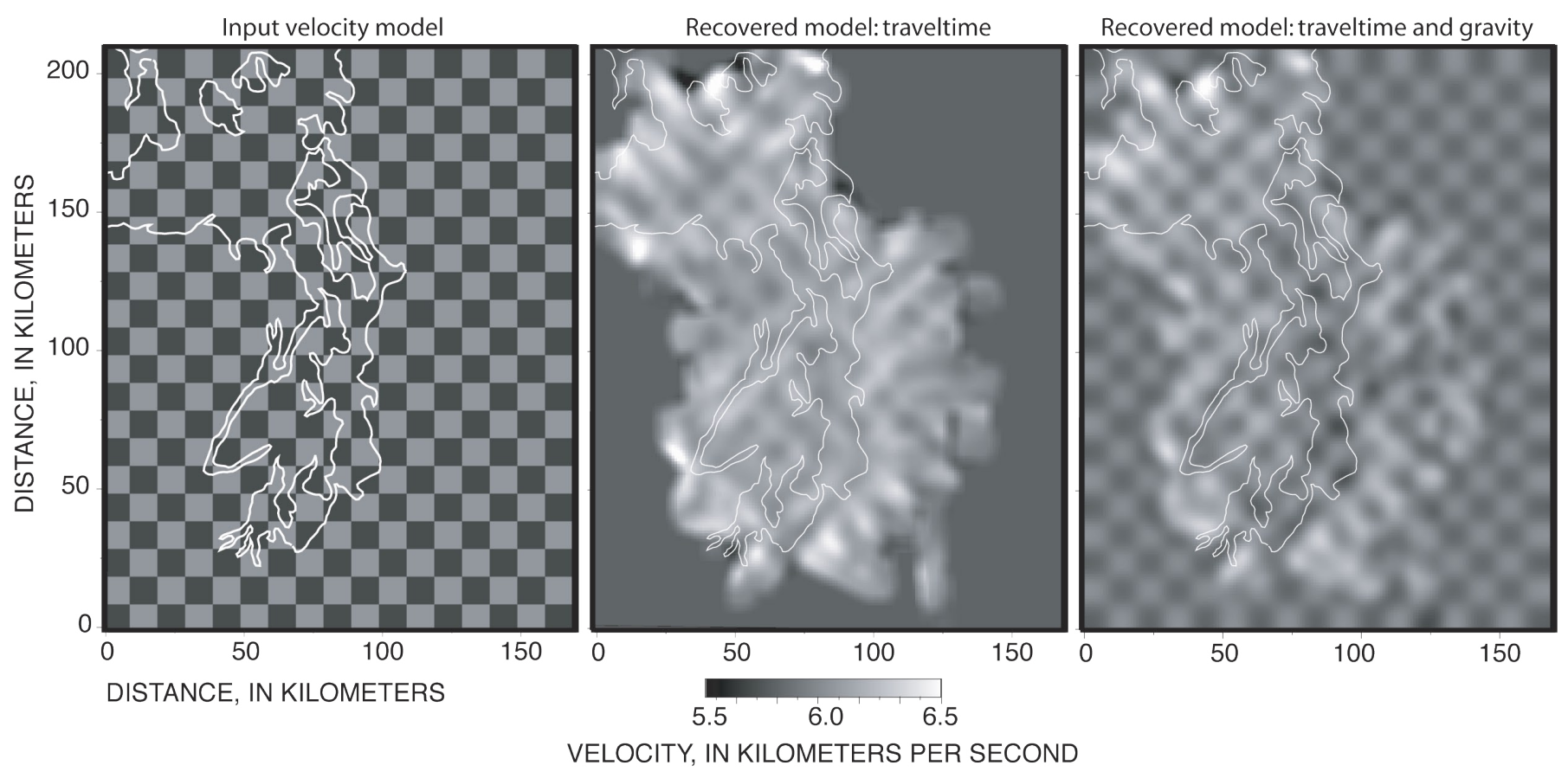

Figure 19. Checkerboard resolution tests of three-dimensional velocity model at $5-\mathrm{km}$ depth. Synthetic traveltime and gravity observations were calculated with the input model using the SHIPS experiment geometry. The two recovered models used traveltimes only and traveltimes in combination with observed gravity. Use of gravity in combination with seismic traveltimes resolves the checkerboard pattern much better than traveltimes alone, and over a larger area. 
the southeastern end of the fault. The combined traveltimegravity model shows additional influence of this fault on Whidbey Island, where a distinct high-velocity anomaly is bounded by the northwest extent of the southern Whidbey Island Fault (fig. 22) but is not evident from the traveltimeonly model. Much of this high-velocity anomaly occurs offshore, where there are many airgun sources but few receivers, causing unreversed seismic arrivals that limit resolution.

A final example is the Everett Basin, which is located north of the Seattle Basin and was poorly resolved by the traveltime model because it lies at the edge of seismic coverage (Brocher and others, 2001; figs. 20,21). Incorporation of the gravity observations introduces this basin into the velocity model where it was previously absent (fig. 22). Even relatively small gravity anomalies can have important effects on the velocity model in the upper crust where seismic coverage is sparse.

It appears that structures around the edges of seismic coverage are better resolved as a result of fitting the gravity anomaly (fig. 22). Subtle changes are also evident within the region of high coverage (figs. 20,22) where the Tacoma Basin and, to a lesser extent, the Seattle Basin have slightly different shapes. The resolution tests showed better recovery of the checkerboard pattern in the region of highest ray coverage (figs. 19, 20); the modifications to the Tacoma and Seattle Basins may thus indicate refinement of these basins in the model, though this is difficult to verify.

\section{Evaluation from Borehole Velocity Data}

Six deep industry boreholes in the study area provide sonic velocity logs (fig. 6). Comparison of the tomography model to these sonic velocity logs suggests that the shallow (upper $3 \mathrm{~km}$ ) velocities are generally well recovered by both velocity models (fig. 23). This comparison, as originally made by Brocher and others (2001), showed that the velocity structure in the upper $3 \mathrm{~km}$ of the traveltime-only model

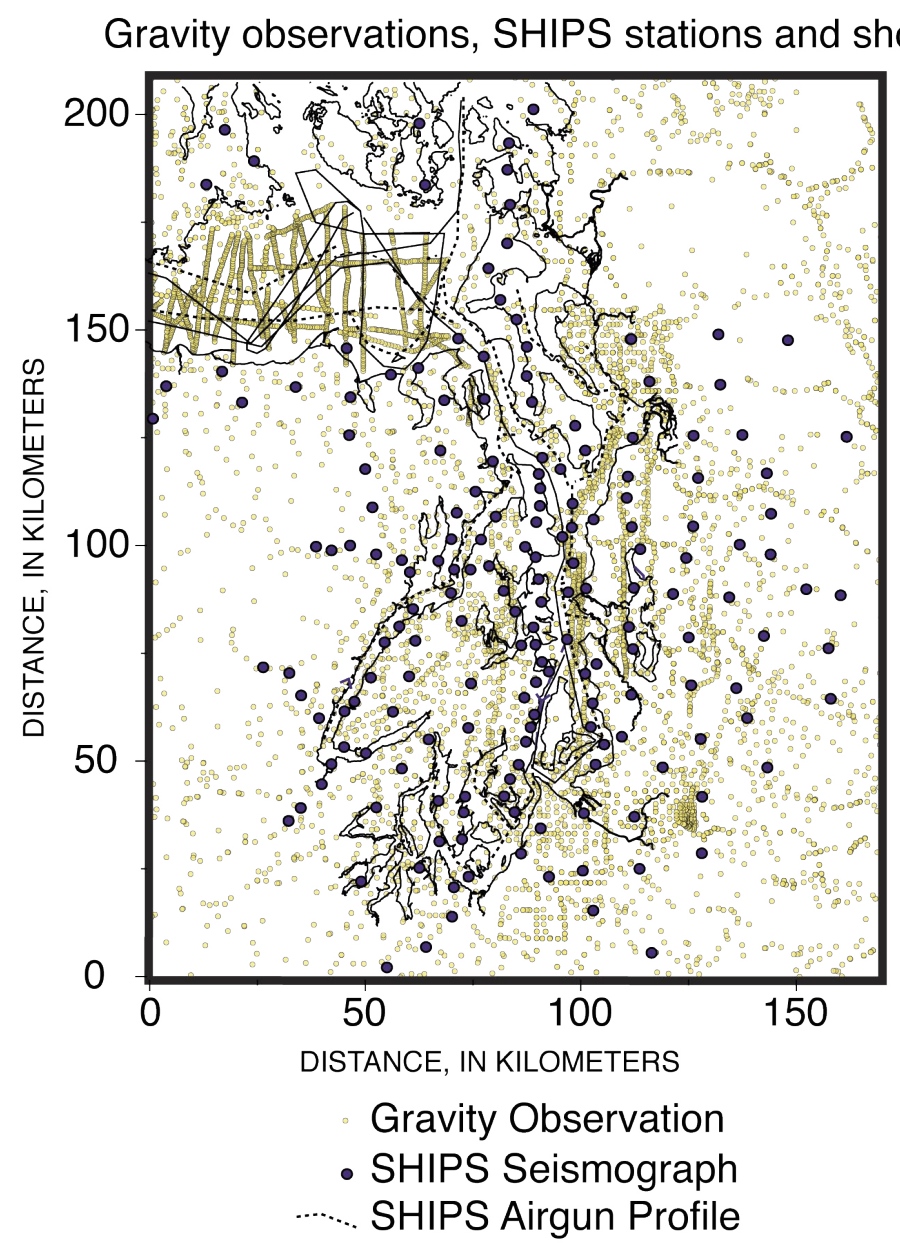

\section{ts}

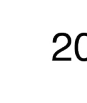

200

150

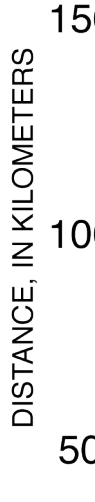

Seismic coverage

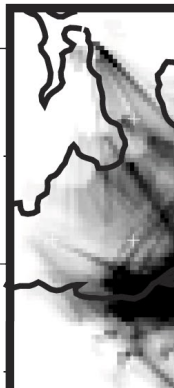

asc

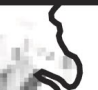

00

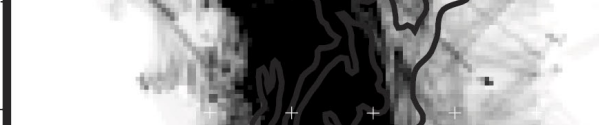

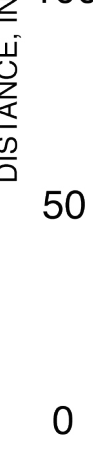

0

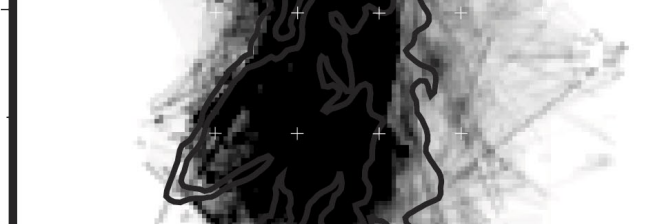

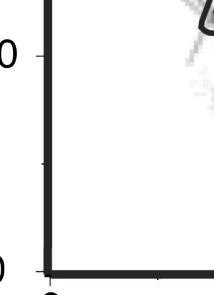

50

$50 \quad 100$

150

DISTANCE, IN KILOMETERS

Figure 20. Comparison (left) between distribution of gravity observations (small yellow dots) and SHIPS seismic sources (dashed lines) and receivers (blue dots) in the Puget Lowland. Gravity coverage is more uniform and the number of observation points is greater than the coverage by wide-angle recorders in the SHIPS seismic experiment. Also shown (right) is seismic-ray coverage at 5-km depth below sea level expressed as a hit count, the number of times a 1-km cubic cell in the model is crossed by seismic raypaths between sources and receivers. The darkest areas have the highest hit counts. 

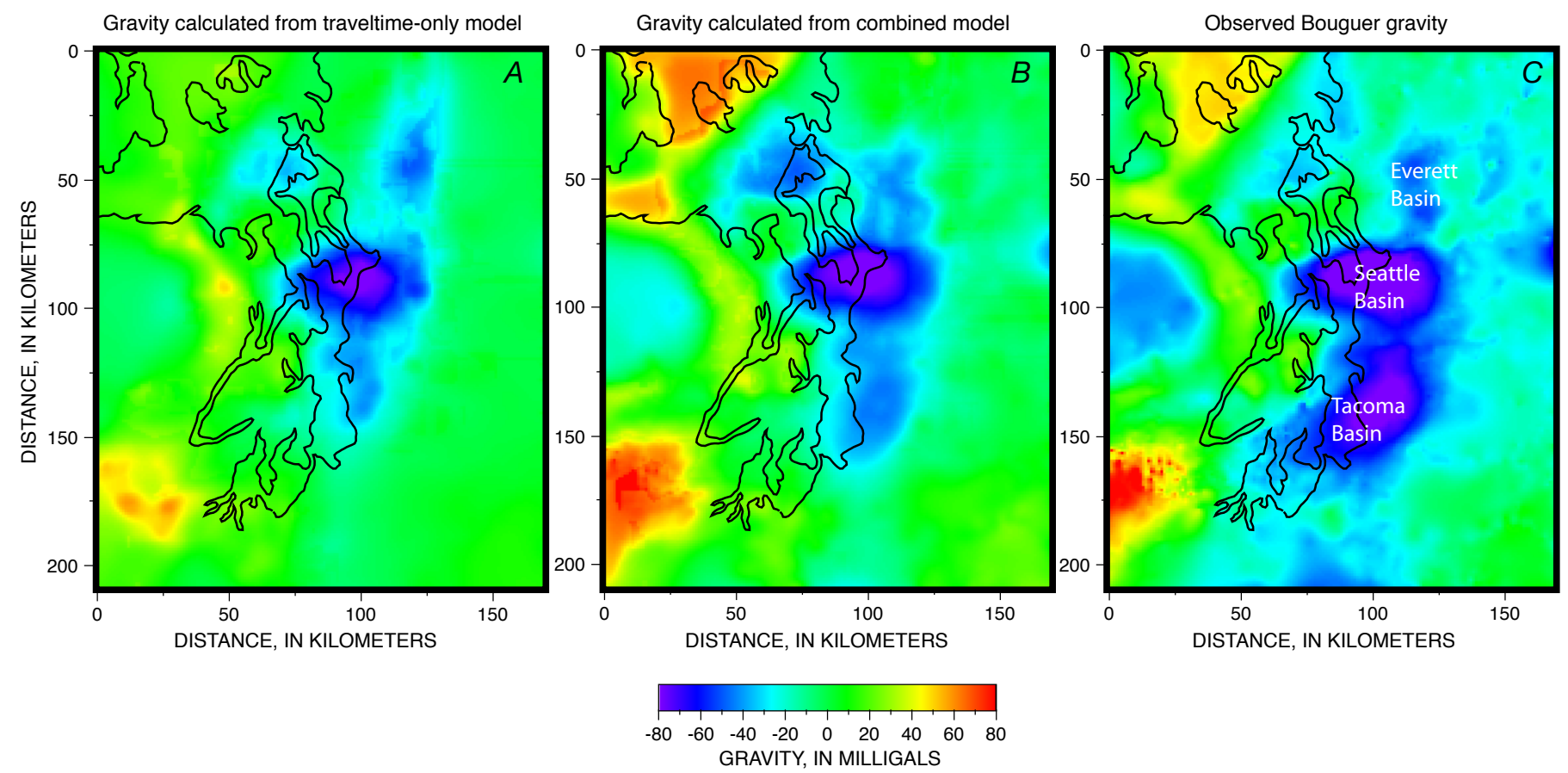

Figure 21. Calculation of the gravity anomaly from velocity models developed from $(A)$ traveltimes only and $(B)$ combined traveltime and gravity analysis in the Puget Lowland. As expected, more features of the observed gravity anomaly $(C)$ are apparent from the combined analysis. This exercise highlights areas like the Tacoma Basin, where the traveltime residuals were satisfied but the full gravity anomaly was not, implying that relatively lower density rocks for a given velocity may fill the basin.

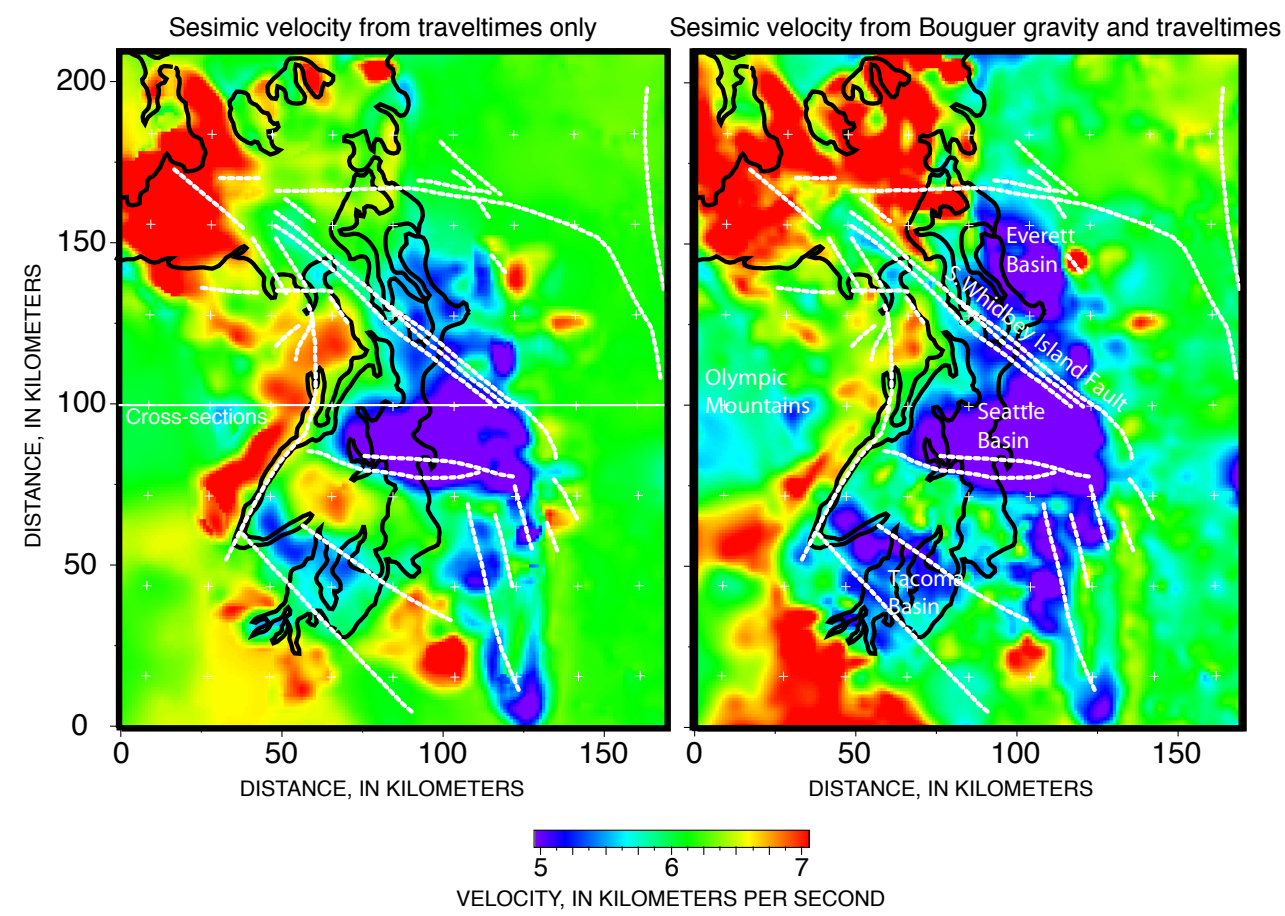

Figure 22. Horizontal (map-view) slices from the three-dimensional model volumes at 5-km depth below sea level are shown from the traveltime-only inversion (left) and the combined gravity-traveltime inversion (right). White dashed lines are crustal faults. Incorporation of gravity highlights features not previously evident, such as the Everett Basin and offset of a high-velocity body along the northwest end of the South Whidbey Island Fault. The image of low-velocity rocks of the Olympic Mountains ringed by higher-velocity, mafic Crescent Formation rocks is improved. East-west line marked "cross sections" gives the location of the vertical slices shown in figure 24. 

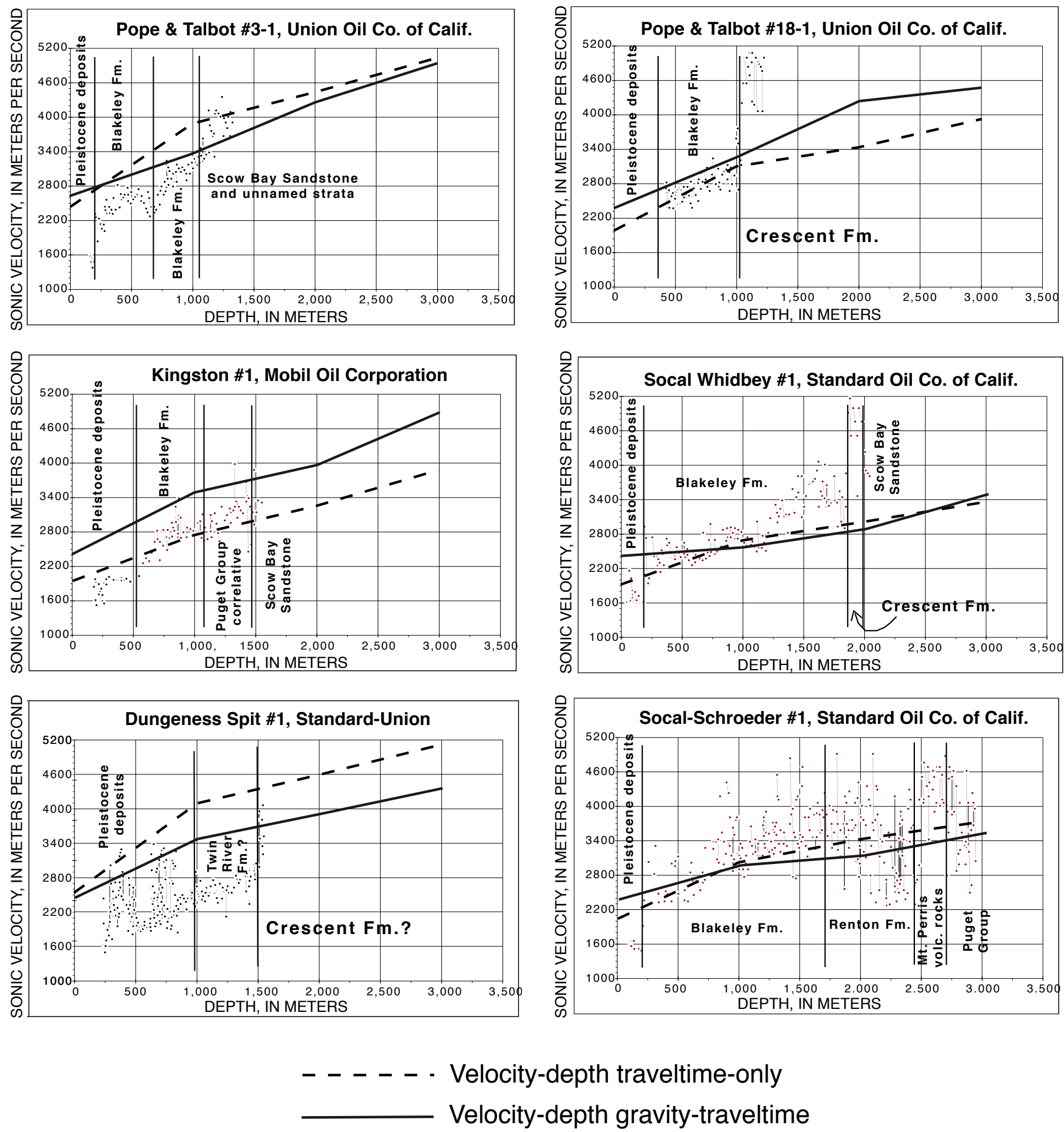

Figure 23. Comparison of tomography results with sonic-log data and lithologies for six boreholes (Brocher and Ruebel, 1998; Brocher and others, 2001). Borehole locations are shown in figure 3. The velocity profile from the model calculated from traveltimes only is shown with a heavy dashed line, and the velocity profile from combined traveltime and gravity inversion is shown with a solid line. 

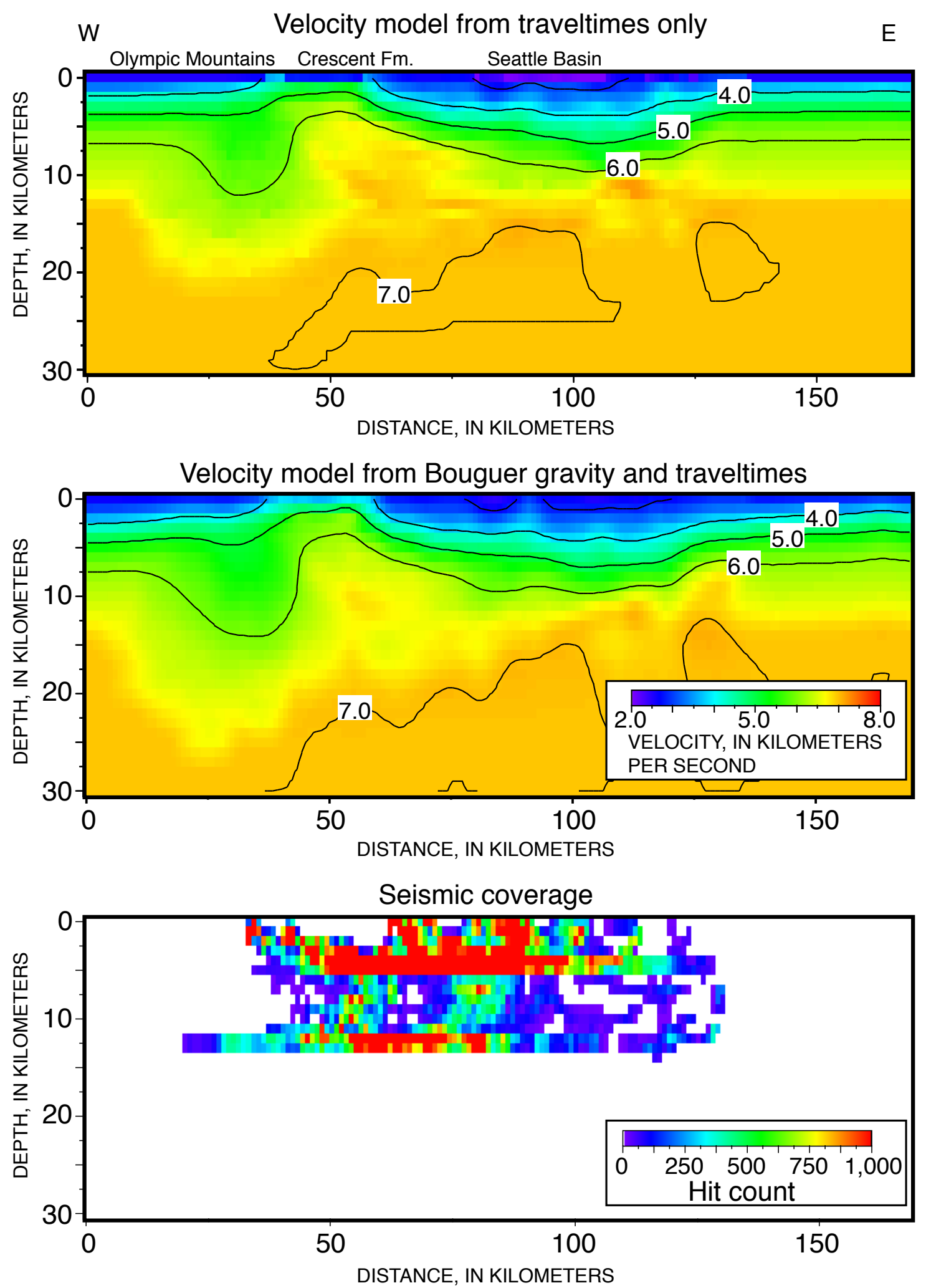

Figure 24. Comparative east-west cross sections from the three-dimensional velocity models derived from combined gravity and traveltime analysis and from traveltime modeling only (see fig. 6 for location). The region constrained by seismic raypaths is shown by the hit-count map below. The velocity structure is subtly changed by introduction of the gravity constraint: The low-velocity rocks of the Olympic Mountains are shifted deeper, and the eastern edge of the Seattle Basin is more completely resolved. Slight variation in velocity structure beneath the depth of seismic coverage $(\sim 15 \mathrm{~km})$ results mostly from smoothing conducted during the gravity inversion. 
matched the data from four of the six boreholes to within 0.2 to $0.3 \mathrm{~km} / \mathrm{s}$, particularly for the sedimentary rocks in the Oligocene Blakeley Formation filling the Seattle Basin. Thin ( $<300 \mathrm{~m}$ thick) layers of high-velocity Crescent Formation in the Socal Whidbey \#1 and Pope and Talbot \#18-1 boreholes were too thin to be resolved by the tomography method (fig. 23). The greatest misfit occured at the Pope and Talbot \#3-1 and Dungeness Spit \#1 wells at the northern end of the tomography model in regions having sparse receivers (figs. 6, 23). Incorporation of gravity improved the fit to wells where seismic coverage was sparse, but degraded the fit slightly where seismic coverage was best, such as at the Mobil Kingston \#1 well. This occurrence illustrates the tradeoffs in seismic resolution that can result from the gravity constraint.

\section{Comparison of Velocity Models in Cross-Section View}

A cross section (location shown in fig. 22) from the velocity model shows how structure was modified by the incorporation of gravity in the inversion. The differences are relatively minor, but potentially important (fig. 24). A deeper zone of low velocity beneath the Olympic Mountains was modeled, with a $\sim 3-\mathrm{km}$ downward shift of isovelocity contours resulting from the observed gravity low in the Olympic Mountains (fig. 21). A higher velocity at the surface is modeled where Crescent Formation volcanic rocks are exposed and where seismic coverage is absent (fig. 24). The modeled shape of the Seattle Basin is changed with the incorporation of gravity; the basin appears more symmetric because the eastern edge is modified from the starting model and is better resolved where seismic coverage fades out. By design, most of the variation occurs where seismic coverage is low or nonexistent. Resolution of basins near their edges may enable more accurate simulation of earthquake strong ground motion.

\section{Conclusions from Seismic and Gravity Modeling of the Puget Lowland Crustal Structure}

Improvement to synthetic and real three-dimensional seismic-velocity models was demonstrated by incorporating gravity modeling as a sequential step in traveltime inversion. The technique is simple and can be easily added to any iterative, grid-based traveltime modeling scheme. Inversions of seismic traveltimes and gravity observations have resolving power in different parts of the crust. Additionally, there are usually more gravity stations than seismic recorders in a given region, and the two data sets often have different spatial distribution. Thus, adding a gravity constraint as a sequential step in the seismic-velocity inversion can significantly improve resolution of shallow crustal structure.

\section{Acknowledgments}

Parts of this work were supported by the German Ministry of Education, Research, Science, and Technology, the U.S. National Earthquake Hazards Reduction Program, the USGS Continental Surveys Program, and the USGS Coastal and Marine Geology Program. Bob Crosson, Ruth Ludwin, and Steve Malone at the University of Washington are acknowledged for helping with arrival-time data from the Pacific Northwest Seismic Network. Reftek seismographs were provided by the IRIS-PASSCAL instrument center at Stanford University; Marcos Alvarez and Anthony Wei supported the controlled-source experiments. Guy Cochrane, Michael Ellis, Gary Ernst, Michael Fisher, Harvey Kelsey, Simon Klemperer, Vicki Langenheim, Kate Miller, Walter Mooney, and Anne Tréhu reviewed various parts of this compilation.

\section{References}

Aprea, C., Unsworth, M., and Booker, J., 1998, Resistivity structure of the Olympic Mountains and Puget Lowlands: Geophysical Research Letters, v. 25, p. 109-112.

Atwater, B.F., 1996, Coastal evidence for great earthquakes in western Washington, in Rogers, A.M., Walsh, T.J., Kockelman, W.J., and Priest, G.R., eds., Assessing earthquake hazards and reducing risk in the Pacific Northwest: U.S. Geological Survey Professional Paper 1560, p. 77-90.

Atwater, B.F., and Moore, A. L., 1992, A tsunami about 1000 years ago in Puget Sound, Washington: Science, v. 258, p. 1614-1617.

Babcock, R.S., Burmester, R.F., Engebretson, D.C. and Warnock, A., 1992, A rifted margin origin for the Crescent basalts and related rocks in the northern coast range volcanic province, Washington and British Columbia: Journal of Geophysical Research, v. 97, p. 6799-6821.

Beck, M.E., Jr., and Burr, C.D., 1979, Paleomagnetism and tectonic significance of the Goble volcanic series, southwestern Washington: Geology, v. 7, p. 175-179.

Best, M.G., 1982, Igneous and Metamorphic Petrology: New York, W.H. Freeman and Company, 630 pp.

Blackwell, D.D., Steele, J.L., and Kelley, S., 1990, Heat flow in the State of Washington and thermal conditions in the Cascade Range: Journal of Geophysical Research, v. 95, p. 1949519516.

Blakely, R.J., 1995, Potential theory in gravity and magnetic applications: Cambridge, Cambridge University Press, 441 pp.

Brandon, M.T., and Calderwood, A.R., 1990, High-pressure metamorphism and uplift of the Olympic subduction complex: Geology, v. 18, p. 1252-1255. 
Brandon, M.T., and Vance, J.A., 1992, Tectonic evolution of the Cenozoic Olympic subduction complex, Washington State, as deduced from zircon fission track ages for detrital zircons: American Journal of Science, v. 292, p. 565-636.

Brandon, M.T., Roden-Tice, M.K., and Garver, J.I., 1998, Late Cenozoic exhumation of the Cascadia accretionary wedge in the Olympic Mountains, NW Washington State: Geological Society of America Bulletin, v. 110, p. 985-1009.

Brocher, T.M., and Ruebel, A.L., 1998, Compilation of 29 sonic and density logs from 23 oil test wells in western Washington State: U.S. Geological Survey Open File Report 98-249, 41 p.

Brocher, T.M., Parsons, Tom, Creager, K.C., Crosson, R.S., Symons, N.P., Spence, G.D., Zelt, B.C., Hammer, P.T., Hyndman, R.D., Mosher, D.C., Tréhu, A.M., Miller, K.C., ten Brink, U.S., Fisher, M.A., Pratt, T.L., Alvarez, M.G., Beaudoin, B.C., Louden, K.E., and Weaver, C.S., 1999, Wide-angle seismic recordings from the 1998 Seismic Hazards Investigation of Puget Sound (SHIPS), western Washington and British Columbia: U.S. Geological Survey Open File Report 99-314, 110 p.

Brocher, T.M., Parsons, Tom, Blakely, R.J., Christensen, N.I., Fisher, M.A., and Wells, R.E., 2001, Upper crustal structure in Puget Lowland, Washington; Results from the 1998 seismic hazards investigation in Puget Sound: Journal of Geophysical Research, v. 106, p. 13541-13564.

Bucknam, R.C., Hemphill-Haley, E., and Leopold, E.B., 1992, Abrupt uplift within the past 1700 years at southern Puget Sound, Washington: Science, v. 258, p. 1611-1614.

Byrne, D.E, Wang, W., and Davis, D.M., 1993, Mechanical role of backstops in the growth of forearcs: Tectonics, v. 12, p. 123144.

Calvert, A.J., 1996, Seismic reflection constraints on imbrication and underplating of the northern Cascadia margin: Candadian Journal of Earth Science, v. 33, p. 1294-1307.

Catchings, R.D., and Mooney, W.D., 1988, Crustal structure of the Columbia Plateau; evidence for continental rifting: Journal of Geophysical Research, v. 93, p. 459-474.

Christensen, N.I., and Mooney, W.D., 1995, Seismic velocity structure and composition of the continental crust; A global view: Journal of Geophysical Research, v. 100, p. 9761-9788.

Clowes, R.M., Brandon, M.T., Green, A.G., Yorath, C.J., Sutherland, A.S., Kanesewich, E.R., and Spencer, C., 1987, LITHOPROBE - southern Vancouver Island; Cenozoic subduction complex imaged by deep seismic reflections: Canadian Journal of Earth Science, v. 24, p. 31-51.

Crosson, R.S., and Owens, T.J., 1987, Slab geometry of the Cascadia subduction zone beneath Washington from earthquake hypocenters and teleseismic converted waves: Geophysical Research Letters, v. 14, p. 824-827.
DeMets, C. Gordon, R.G., Argus, D.F., and Stein, S., 1990. Current plate motions: Geophysical Journal International, v. 101, p. 425-478.

Dewey, J.W., Hill, D.P., Ellsworth, W.L., and Engdahl, E.R., 1989, Earthquakes, faults, and the seismotectonic framework of the contiguous United States, in Pakiser, L. C., and Mooney, W. D., eds., Geophysical framework of the continental United States: Geological Society of America Memoir 172, p. 541-576.

Duncan, R.A., 1982, A captured island arc chain in the Coast Range of Oregon and Washington: Journal of Geophysical Research, v. 87, p. 10827-10837.

England, P.C., and Wells, R.E., 1991, Neogene rotations and quasicontinuous deformation of the Pacific Northwest continental margin: Geology, v. 19, p. 978-981.

Finn, C., 1990, Geophysical constraints on Washington convergent margin structure: Journal of Geophysical Research, v. 95, p. 19533-19546.

Finn, C., Phillips, W.M., and Williams, D.L., 1991, Gravity and terrane maps of Washington: U.S. Geological Survey Geophysical Investigations Map GP-988, scale 1:125,000.

Fisher, M.A., Brocher, T.M., Hyndman, R.D., Tréhu, A.M., Weaver, C.S., Creager, K.C., Crosson, R.S., Parsons, Tom, Cooper, A.K., Mosher, D., Spence, G., Zelt, B.C., Hammer, P.T., ten Brink, U., Pratt, T. L., Miller, K. C., Childs, J. R., Cochrane, G. R., Chopra, S., and Wailia, R., 1999, Seismic survey probes urban earthquake hazards in Pacific Northwest: EOS, Transactions American Geophysical Union, v. 80, p. 13-17.

Flueh, E., Fisher, M., Scholl, D., Parsons, Tom, ten Brink, U., Klaeschen, D., Kukowski, N., Tréhu, A., Childs, J., Bialas, J., and Vidal, N., 1997, Scientific teams analyze earthquake hazards of the Cascadia subduction zone: EOS, Transactions American Geophysical Union, v. 78, no. 15, p. 153, 157.

Gardner, G.H.F., Gardner, L.W., and Gregory, A.R., 1974, Formation velocity and density; the diagnostic basis for stratigraphic traps: Geophysics, v. 39, p. 770-780.

Gower, H.D., Yount, J.C., and Crosson, R.S., 1985, Seismotectonic map of the Puget Sound region, Washington: U.S. Geological Survey Miscellaneous Investigations Series Map I-1613, scale 1:250,000.

Heaton, T. H., and Hartzell, S.H., 1987, Earthquake hazards on the Cascadia subduction zone: Science, v. 236, p. 162-168.

Heaton, T.H., and Kanamori, H., 1984, Seismic potential associated with subduction in the northwestern United States: Seismological Society of America Bulletin, v. 74, p. 933-941.

Hole, J.A., 1992, Nonlinear high-resolution three-dimensional seismic travel time tomography: Journal of Geophysical Research, v. 97, no. B5, p. 6553-6562. 
Hole, J.A., and Zelt, B.C., 1995, 3-D finite-difference reflection travel times: Geophysical Journal International, v. 121, p. 427434.

Humphreys, E., and Clayton, R.W., 1988, Adaptation of back projection tomography to seismic travel time problems: Journal of Geophysical Research, v. 93, p. 1073-1085.

Hyndman, R.D., and Wang, K., 1993, Thermal constraints on the zone of major thrust earthquake failure; the Cascadia subduction zone: Journal of Geophysical Research, v. 98, p. 2039-2060.

Irving, E., 1979, Paleopoles and paleolatitudes of North America and speculations about displaced terranes: Candadian Journal of Earth Science, v. 16, p. 669-694.

Jarchow, C.M., Catchings, R.D., and Lutter, W.J., 1994, Largeexplosive source, wide-recording aperture, seismic profiling on the Columbia Plateau, Washington: Geophysics, v. 59, p. 259-271.

Johnson, S.Y., Potter, C.J., and Armentrout, J.M., 1994, Origin and evolution of the Seattle fault and Seattle basin, Washington: Geology, v. 22, p. 71-74.

Johnson, S.Y., Potter, C.J., Armentrout, J.M., Miller, J.J., Finn, C., and Weaver, C.S., 1996, The southern Whidbey Island fault, western Washington - an active structure in the Puget Lowland, Washington: Geological Society of America Bulletin, v. 108, p. 334-354.

Johnson, S.Y., Dadisman, S.V., Childs, J.R., and Stanley, W.D., 1999, Active tectonics of the Seattle fault and central Puget Sound, Washington-implications for earthquake hazards: Geological Society of America Bulletin, v. 111, p. 1042-1053.

Kirby, S., Engdahl, E.R., and Denlinger, R., 1996, Intermediate-depth intraslab earthquakes and arc volcanism as physical expressions of crustal and uppermost mantle metamorphism in subducting slabs, in Bebout, G. D., Scholl, D., Kirby, S., and Platt, J., eds., Subduction from top to bottom: American Geophysical Union, Geophysical Monograph, v. 96, p. 195-214.

Lees, J.M., and Crosson, R.S., 1990, Tomographic imaging of local earthquake delay times for three-dimensional velocity variation in western Washington: Journal of Geophysical Research, v. 95, p. 4763-4776.

Magill, J., Cox, A., and Duncan, R., 1981, Tillamook volcanic series; further evidence for tectonic rotation of the Oregon Coast Range: Journal of Geophysical Research, v. 86, p. 2953-2970,.

Massey, N.W.D., 1986, Metchosin igneous complex, southern Vancouver Island; ophiolite stratigraphy developed in an emergent island setting: Geology, v. 14, p. 602-605.

McCrory, P.A., 1996, Tectonic model explaining divergent contraction directions along the Cascadia subduction margin, Washington: Geology, v. 24, p. 929-932.
McFarland, C.R., 1979, Oil and gas exploration in Washington: State of Washington Department of Natural Resources Information Circular 67, 119 pp.

McNeill, L., Piper, K.A., Goldfinger, C., Kulm, L.D., and Yeats, R.S., 1997, Listric normal faulting on the Cascadia continental margin: Journal of Geophysical Research, v. 102, p. 1212312138.

Michaelson, C.A., and Weaver, C.S., 1986, Upper mantle structure from teleseismic $\mathrm{P}$ wave arrivals in Washington and northern Oregon: Journal of Geophysical Research, v. 91, p. 2077-2094.

Miller, K.C., Keller, G.R., Gridley, J.M., Luetgert, J.H., Mooney, W.D., and Thybo, H., 1997, Crustal structure along the flank of the Cascades, western Washington: Journal of Geophysical Research, v. 102, p. 17857-17873.

Moran, S. C., 1997, Three-dimensional P-wave velocity structure in the greater Mount Rainier area from local earthquake tomography: Seattle, University of Washington, Ph.D. dissertation, $167 \mathrm{p}$.

Paine, J.G., 1982, Crustal structure of volcanic arcs based on physical properties of andesites, volcaniclastic rocks, and inclusions in the Mt. St. Helens lava dome: Seattle, University of Washington, M.S. thesis, 138 p.

Parsons, Tom, McCarthy, J., Kohler, W.M., Ammon, C.J., Benz, H.M., Hole, J.A., and Criley, E.E., 1996, The crustal structure of the Colorado Plateau, Arizona; application of new long-offset seismic data analysis techniques: Journal of Geophysical Research, v. 101, p. 11173-11194.

Parsons, Tom, Tréhu, A.M., Luetgert, J.H., Miller, K., Killbride, F., Wells, R.E., Fisher, M.A., Flueh, E., ten Brink, U.S., and Christensen, N.I., 1998, A new view into the Cascadia subduction zone and volcanic arc; implications for earthquake hazards along the Washington margin: Geology, v. 26, p. 199-202.

Parsons, T., Wells, R.E., Flueh, E., ten Brink, U.S., and Fisher, M.A., 1999, Three-dimensional velocity structure of Siletzia and other accreted terranes in the Cascadia fore arc of Washington: Journal of Geophysical Research, v. 104, p. 18015-18039.

Pezzopane, S.K., and Weldon, R.J., 1993, Tectonic role of active faulting in central Oregon: Tectonics, v. 12, p. 1140-1169.

Pratt, T.L., Johnson, S., Potter, C., Stephenson, W., and Finn, C., 1997, Seismic reflection images beneath Puget Sound, western Washington State; the Puget Lowland thrust sheet hypothesis: Journal of Geophysical Research, v. 102, p. 27469-27489.

Saltus, R.W., 1993, Upper-crustal structure beneath the Columbia River basalt group, Washington; gravity interpretation controlled by borehole and seismic studies: Geological Society of America Bulletin, v. 105, p. 1247-1259. 
Shaw, P.R., and Orcutt, J.A., 1985, Waveform inversion of seismic refraction data and applications to young Pacific crust: Geophysical Journal of the Royal Astronomical Society, v. 82, no. 3, p. 375-414.

Simpson, R.W., and Cox, A., 1977, Paleomagnetic evidence for tectonic rotation of the Oregon Coast Range: Geology, v. 5, p. 585-589.

Snavely, P.D., 1987, Tertiary geologic framework, neotectonics, and petroleum potential of the Oregon-Washington continental margin, in Scholl, D.W., Grantz, Arthur, and Vedder, J. G., eds., Geology and resource potential of the continental margin of western North America and adjacent ocean basins-Beaufort Sea to Baja California: Circum-Pacific Council for Energy and Mineral Resources Earth Science Series, 6, 305-335.

Snavely, P.D., and Wagner, H.C., 1982, Geologic cross section across the continental margin of southwestern Washington: U.S. Geological Survey Open File Report 82-459, 10 pp.

Snavely, P.D., and Wells, R.E., 1996, Cenozoic evolution of the continental margin of Oregon and Washington, in Rogers, A.M., Walsh, T.J., Kockelman, W.J., and Priest, G.R., eds., Assessing earthquake Hazards and reducing risk in the Pacific Northwest: U. S. Geological Survey Professional Paper 1560, p. 161-182.

Snavely, P.D., MacLeod, N.S., and Wagner, H.C., 1968, Tholeiitic and alkalic basalts of the Eocene Siletz River volcanics, Oregon Coast Range: American Journal of Science, v. 266, p. 454-481.

Stanley, W.D., Johnson, S.Y., Qamar, A.I., Weaver, C.S., and Williams, J.M., 1996, Tectonics and seismicity of the southern Washington Cascade Range: Seismological Society of America Bulletin, v. 86, p. 1-18.

Symons, N.P., and Crosson, R.S., 1997, Seismic velocity structure of the Puget Sound region from 3-D non-linear tomography: Geophysical Research Letters, v. 24, p. 2593-2596.

Taber, J.J., and Lewis, B.T.R., 1986, Crustal structure of the Washington continental margin from refraction data: Seismological Society of America Bulletin, v. 76, p. 1011-1024.

Tabor, R.W., and Cady, W.M., 1978, The structure of the Olympic Mountains, Washington — analysis of a subduction zone: U. S. Geological Survey Professional Paper 1033, 38 p.

Thurber, C.H., 1993, Local earthquake tomography: velocities and $\mathrm{Vp} / \mathrm{Vs}$ - theory, in Iyer, H.M, and Hirahara, K., eds., Seismic tomography; theory and practice: Chapman and Hall, London, p. $663-683$.
Tichelaar, B.W., and Ruff, L.J., 1993, Depth of seismic coupling along subduction zones: Journal of Geophysical Research, v. 98, p. 2017-2037.

Tréhu, A.M., Asudeh, I., Brocher, T.M., Luetgert, J., Mooney, W.D., Nabelek, J.L., and Nakamura, Y., 1994, Crustal architecture of the Cascadia forearc: Science, v. 266, p. 237-243.

Tréhu, A. M, Lin, G., Maxwell, E., and Goldfinger, C., 1995, A seismic reflection profile across the Cascadia subduction zone offshore central Oregon; new constraints on methane distribution and crustal structure: Journal of Geophysical Research, v. 100 , p. 15101-15116.

Vidale, J. E., 1990, Finite-difference calculation of traveltimes in three dimensions: Geophysics, v. 55, p. 521-526.

Walsh, T.J., Korosec, M.A., Phillips, W.M., Logan, R.L., and Schasse, H.W., 1987, Geologic map of Washington, southwest quadrant: Washington Division of Geology and Earth Resources Geologic Map GM-34, scale 1:250,000.

Wang, K., Mulder, T., Rogers, G.C., and Hyndman, R.D., 1995, Case for very low coupling stress on the Cascadia subduction fault: Journal of Geophysical Research, v. 100, p. 12907-12918.

Warnock, A.C., Burmeister, R.F., and Engebretson, D.C., 1993, Paleomagnetism and tectonics of the Crescent formation, northern Olympic Mountains: Journal of Geophysical Research, v. 98, p. 11729-11742.

Wells, R.E., 1990, Paleomagnetic rotations and the Cenozoic tectonics of the Cascade arc, Washington, Oregon, and California: Journal of Geophysical Research, v. 95, p. 19409-19417.

Wells, R.E., and Coe, R.S., 1985, Paleomagnetism and geology of Eocene volcanic rocks of southwest Washington, implications for mechanisms of tectonic rotation: Journal of Geophysical Research, v. 90, p. 1925-1947.

Wells, R.E., and Weaver, C.S., 1993, Cenozoic deformation of Pacific Northwest coastal regions, in Frizzell, V.A., ed., Proceedings of the National Earthquake Prediction Evaluation Council: U.S. Geological Survey Open File Report 93-333, p. 14-16.

Wells, R.E., Engebretson, D.C., Snavely, P.D., and Coe, R.S., 1984, Cenozoic plate motions and the volcano-tectonic evolution of western Oregon and Washington: Tectonics, v. 3, p. 275-294.

Wells, R.E., Weaver, C.S., and Blakely, R.J., 1998, Fore arc migration in Cascadia and its neotectonic significance: Geology, v. 26, p. 759-762. 